\title{
Cytochrome P450 2A5 and Bilirubin Mechanisms of Gene Regulation and Cytoprotection
}

\author{
by \\ Sangsoo Kim
}

\author{
A Thesis \\ presented to
}

The University of Guelph

In partial fulfillment of requirements

for the degree of

Master of Science

in

Biomedical Sciences

Guelph, Ontario, Canada

(C) Sangsoo Kim, January, 2013 


\begin{abstract}
CYTOCHROME P450 2A5 AND BILIRUBIN: MECHANISMS OF GENE REGULATION AND CYTOPROTECTION
\end{abstract}

Sangsoo Kim

Advisor

University of Guelph, 2012

Dr. G.M. Kirby

Murine cytochrome P450 2A5 (CYP2A5) is an interesting enzyme for its unique regulation and its involvement in liver injury caused by various well-known pathological conditions or hepatotoxins. It has been reported that CYP2A5 is upregulated following exposure to chemical hepatotoxins and during pathophysiological conditions in which the levels of most Cytochrome P450s are either unchanged or down-regulated. Recently bilirubin has been identified as the first endogenous substrate for CYP2A5 and it has been suggested that CYP2A5 plays a major role in bilirubin clearance as an alternative mechanism to BR conjugation by UGT1A1. This study investigated the mechanisms of gene regulation and cytoprotective role of CYP2A5 in response to bilirubin treatment in liver. Our results demonstrate that bilirubin induces CYP2A5 expression at the mRNA and protein levels by increasing CYP2A5 transcription via a mechanism that involves Nrf2 activation. Furthermore, our results suggest that induced CYP2A5 plays a cytoprotective role against bilirubin toxicity by directly lowering the cellular levels of bilirubin and by inhibiting caspase-3 activation. 


\section{ACKNOWLEDGEMENTS}

First and foremost, I would like to express my sincere thanks to my supervisor Dr. Gordon Kirby, for giving me a great opportunity to work at his laboratory. He has been always patient, helpful, and incredibly informative throughout my graduate studies. His guidance, support, and encouragement have made my past two years of time an enjoyable learning experience. I am also grateful for the helpful advice and support of the members of my advisory committee Drs. Jim Squires and Tony Hayes.

I would like to also thank Dr. Monica Antenos for her support and guidance throughout past two years. Without her presence in the lab, my project would have never been successful. Her invaluable encouragement and advice are greatly appreciated.

Special thanks to Yanping Lou (Department of Animal Science) for processing my samples at the HPLC facility. Thanks also to Lisa Skog and Allison MacKay for taking care of the supplies for my experiments and for their technical assistance. The support from Sally, Frances, Kim, and Wendy from Biomedical Science Department are also appreciated.

I would like to also thank all the members of the Kirby lab, both past and present for their friendship, guidance, and support. The hours I spent in and out of the lab would have been so miserable without you all. Thanks also to all the graduate students and faculty members who provided support and friendship. 
It has been such a memorable and exciting learning experience for past two years. I am very grateful for the funding from Ontario Veterinary College MSc Scholarship and the Natural Sciences and Engineering Research Council, which made my project happen. Finally, I would like to thank my family and friends for their supports and love. I could not have completed my journey without you. 


\section{DECLARATION OF WORK PERFORMED}

I declare that with exception of the item indicated below, all the work reported in this thesis was performed by me. HPLC analysis of Hepa 1-6 media samples for the 7ethoxycoumarin deethylation assay was performed by Yanping Lou in the Department of Animal Science. 


\section{TABLE OF CONTENTS}

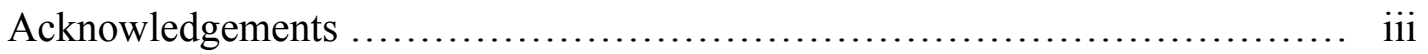

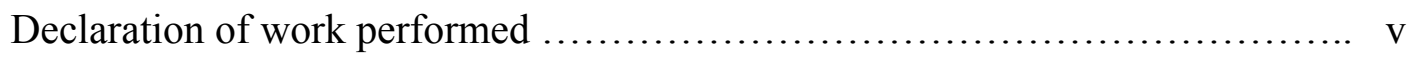

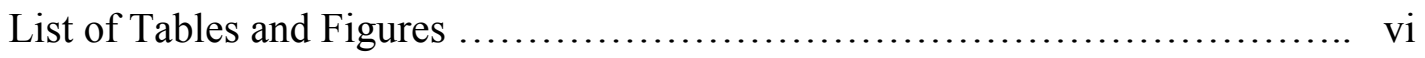

List of Abbreviations .................................................... xi

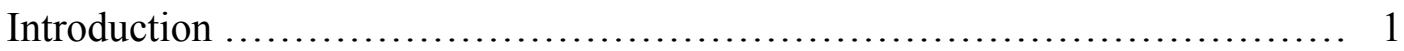

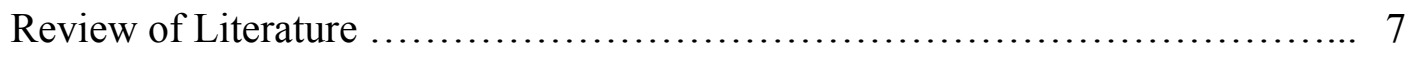

Cytochrome P450 enzyme ......................................... 7

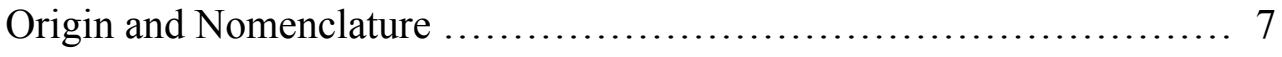

Cytochrome P450 2A5 …........................................ 8

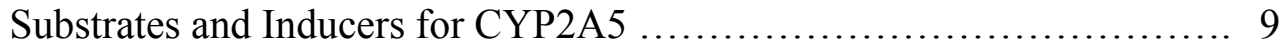

Pathophysiological states associated with CYP2A5 .................. 10

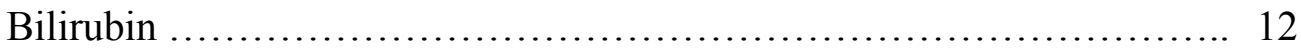

Bilirubin metabolism .............................................. 13

Dual characteristics of bilirubin ..................................... 14

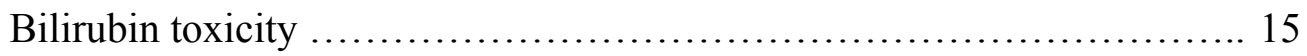

CYP2A5 in bilirubin metabolism .................................. 18

Transcriptional regulation of Cyp2a5 .............................. 20

Post-transcriptional regulation of Cyp2a5 ........................... 24

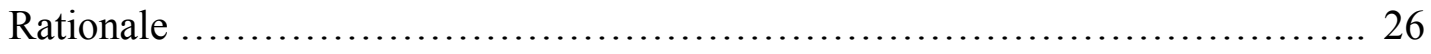

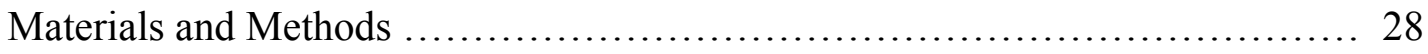

Part 1. Animal model and cell culture ............................... 28

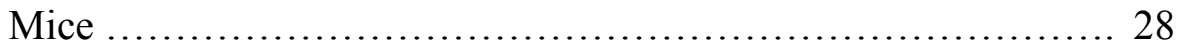


Mouse liver perfusion ......................................... 28

Preparation of primary cultures of mouse hepatocytes .............. 29

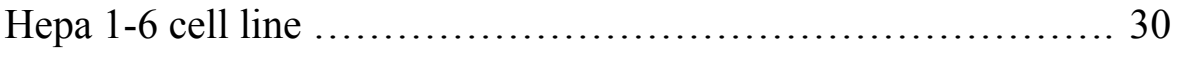

Bilirubin solubilization .................................... 31

Part 2. Regulation of CYP2A5 by BR ............................... 31

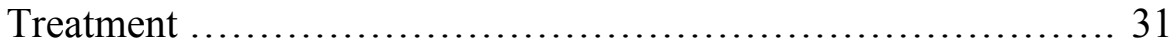

RNA isolation and reverse transcription ......................... 31

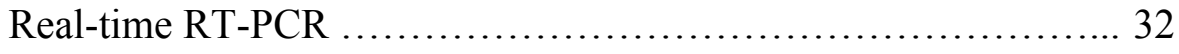

Western blotting ................................................ 33

Luciferase reporter constructs .................................. 34

Transfection of primary mouse hepatocytes ..................... 34

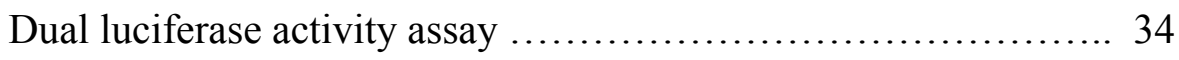

Part 3. Cytoprotective role of CYP2A5 in BR toxicity .................. 36

Transfection of Hepa 1-6 with CYP2A5 overexpression vectors ... 36

CYP2A5 activity assay: 7-ethoxycoumarin deethylation assay ..... 37

Western blotting ........................................... 38

Part 4. Bilirubin disappearance activity .............................. 39

Transfection of Hepa 1-6 with CYP2A5 overexpression vectors ... 39

Microsomal protein extraction ................................ 39

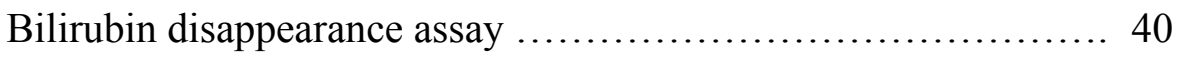

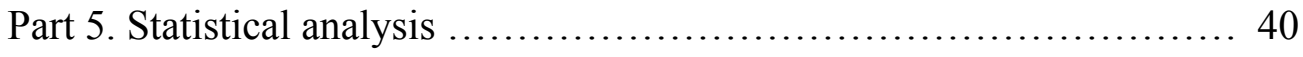


Results

BR induces CYP2A5 mRNA and protein expression in mouse primary

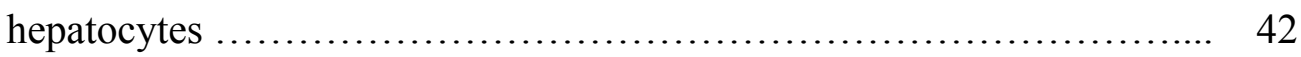

BR induction of CYP2A5 mRNA may not be directly regulated in hepatocytes

CYP2A5 induction by BR is mediated by Nrf2

Transcriptional activation of CYP2A5 by BR involves a StRE in the CYP2A5

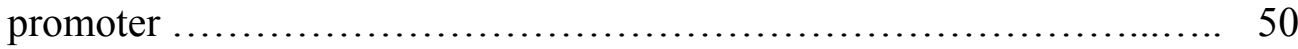

CYP2A5 induction by BR requires Nrf2 ....................... 50

BR activates caspase-3 cleavage in Hepa 1-6 and mouse primary hepatocytes

Overexpressed CYP2A5 is function in Hepa $1-6 \ldots \ldots \ldots \ldots \ldots \ldots \ldots \ldots \ldots 5$

CYP2A5 overexpression partially blocks BR-induced caspase-3 activation in

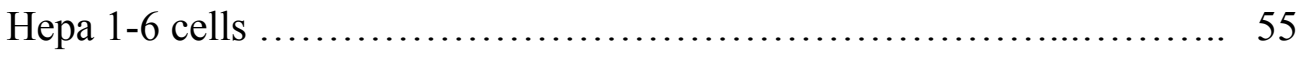

CYP2A5 overexpressing microsomes have increased BR degradation rate

Discussion 60

Summary and Conclusions 68

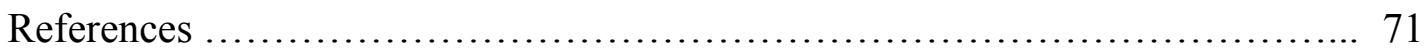

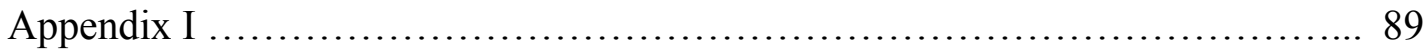

Appendix II ........................................................ 100 


\section{LIST OF TABLES}

Table 1.1 Chemical inducers of CYP2A5 ............................ 11

Table 1.2 Pathophysiological states associated with increased CYP2A5 level ... 12

\section{LIST OF FIGURES}

Figure 1. Effects of BR on CYP2A5 mRNA expression ..................... 43

Figure 2. Effects of BR on CYP2A5 protein expression ..................... 44

Figure 3. Effects of BR on Cyp2a5-5'-luciferase activities in C57BL/6 mouse primary

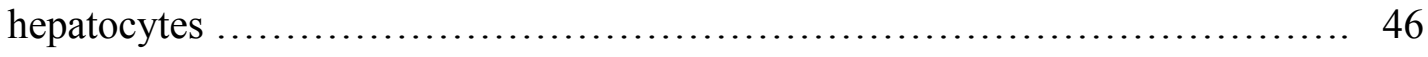

Figure 4. Nrf2 increases CYP2A5 transcription in primary mouse hepatocytes ... 48 Figure 5. BR increases CYP2A5 transcription in primary mouse hepatocytes in the

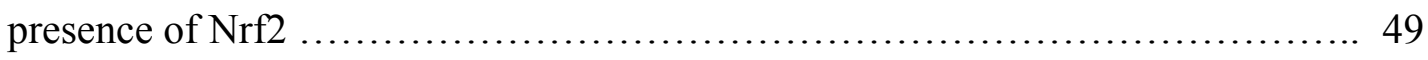

Figure 6. Effect of Nrf2 cotransfection on Cyp2a5-5'-luciferase activities in different reporter constructs transfected in C57BL/6 mouse primary hepatocytes ......... 51

Figure 7. BR-mediated increased CYP2A5 transcription requires the Nrf2 response element in the CYP2A5 promoter ..................................... 52

Figure 8. Effect of BR on caspase-3 cleavage in mouse primary hepatocytes and Hepa

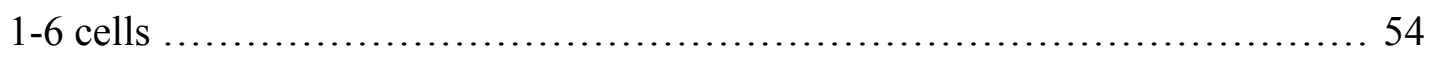

Figure 9. Optimization of transfection conditions for CYP2A5 overexpression in Hepa1-6

Figure 10. Effect of CYP2A5 and POR overexpression on BR-induced caspase-3

cleavage in Hepa 1-6 cells 57 
Figure 11. CYP2A5 and POR overexpression in microsomal fraction of Hepa 1-6 and

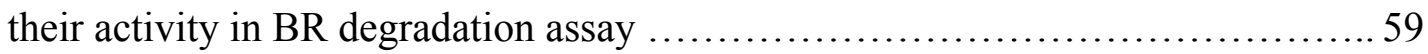

Figure D1. Chemical structures of some nitrogen heterocycle substrates, inducers, or

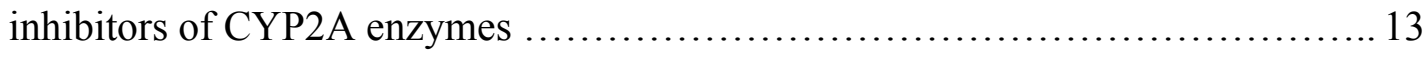




\section{LIST OF ABBREVIATIONS}

3-MC 3-methylcholanthrene

AHR Aryl hydrocarbon receptor

ANOVA Analysis of variance

APAF1 Apoptotic protease activating factor

ARNT Aryl hydrocarbon receptor nuclear translocator

$\beta$-NF $\beta$-naphthoflavone

BIP Binding immunoglobulin protein

BR Bilirubin

BVR Biliverdin reductase

CAR Constitutive androstane receptor

CAR-RE CAR-responsive element

$\mathrm{CdCl}_{2}$ Cadmium chloride

CHX Cyclohexamide

CYP Cytochrome P450

$\mathrm{CO}_{2}$ Carbon dioxide

DISC Death-inducing signaling complex

DMEM Dulbecco's Modified Eagle's medium

EGTA Ethylene glycol tetraacetic acid

ER Endoplasmic reticulum

ERK Extracellular signal-regulated kinase

FBS Fetal Bovine Serum 
GAPDH Glyceraldehyde 3-phosphate dehydrogenase

GRP Glucose-regulated protein

GST Glutathione-S-transferase

HBSS Hanks' balanced salt solution

HEPES 4-(2-hydroxyethyl)-1-piperazineethanesulfonic acid

HNF-4 $\alpha$ Hepatic nuclear factor-4-alpha

hnRNPA1 Nuclear ribonucleoprotein A1

HO Heme oxygenase

HPLC High-performance Liquid Chromatography

HRP Horseradish peroxidase

$\mathrm{iCa}^{2+}$ Intracellular calcium

ITS Insulin-Transferrin-Selenium

Keap1 Kelch-like ECH associating protein 1

Mafs Small musculo-aponeurotic fibrosarcoma proteins

M-MLV RT Murine-Moloney Leukemia Virus reverse transcriptase

NF-I Nuclear factor I

NNK Tobacco-specific carcinogen 4-(methylnitrosamino)-1-(3-pyridyl)-

1-butanone

Nrf2 Nuclear factor-E2 p45-related factor 2

PB Phenobarbital

PBS Phosphate Buffered Saline

PCR Polymerase chain reaction

PGC-1 $\alpha$ Peroxisome proliferator-activated receptor $\gamma$ coactivator 
POR Porcine P450-oxidoreductase/P450 NADPH reductase

PXR Pregnane X-receptor

RNS Reactive nitrogen species

ROS Reactive oxygen species

RT-PCR Real-time reverse transcription polymerase chain reaction

RXR Retinoid X receptor

SEM Standard error of the mean

SDS-PAGE Sodium dodecyl sulfate polyacrylamide gel electrophoresis

StRE Stress response element

TCDD 2,3,7,8-tetracholorodibenzo- $p$-dioxin

UGT Diphosphoglucuronate glucuronosyltransferase

UPR Unfolded protein response

USF Upstream stimulatory factor

XRE Xenobiotic response element

XREM Xenobiotic-responsive enhancer module 


\section{INTRODUCTION}

Cytochrome P450s (CYPs) are a superfamily of oxidative heme-thiolate enzymes found in nearly all species. CYPs are essential enzymes involved in the metabolism of a wide range of endobiotics and xenobiotics. The substrates for CYPs are metabolized primarily through CYPs-catalyzed phase I reaction of drug metabolism, which involves dehydrogenation/hydrogenation, oxidation/reduction, hydrolysis, and monooxygenation (Porter and Coon, 1991; Meyer, 1996). These phase I reactions catalyzed by CYPs in general, convert the parent compounds into more hydrophilic metabolites to facilitate their excretion from the body (Testa and Kramer, 2007). However, biologically neutral parent substrates can also be bioactivated to form more toxic, mutagenic, or even carcinogenic products (Porter and Coon, 1991; Guengerich, 2001).

Since the first discovery, CYPs have been classified by their sequence homology, gene organization, and chromosomal location, and to date, more than 11,200 sequences have been identified in over 970 CYP families in animals, plants, and microorganisms (Nelson et al., 1996). These enzymes have been also shown to be involved in the metabolism of various drugs and endogenous compounds, and their expression is affected by pathological conditions, gender differences, and genetic polymorphisms.

The present study focuses on a specific CYP isozyme of the 2A class namely CYP2A5. CYP2A5 is a murine orthologue of the human nicotine-metabolizing enzyme, CYP2A6, which was first identified as coumarin 7-hydroxylase (Pelkonen et al., 2000). CYP2A5 is primarily located in the endoplasmic reticulum and mitochondrial membranes of the liver and olfactory mucosa of mice (Juvonen et al., 1988; Su et al., 1996; Piras et 
al., 2003; Genter et al., 2006; Sangar et al., 2010). CYP2A5 is an interesting enzyme for its unique regulation and its involvement in liver injury caused by various well-known pathological conditions or hepatotoxins. It has been reported that CYP2A5 is upregulated following exposure to chemical hepatotoxins and during pathophysiological conditions in which the levels of most CYPs are either unchanged or down-regulated (Juvonen et al., 1985; Camus et al., 1996; Kojo et al., 1998; Kirby et al., 2011). The identified chemical inducers of CYP2A5 have varying structures and origin, and include various hepatotoxins, heavy metals, hormones, and porphyrinogenic compounds (Juvonen et al., 1985; Mangoura et al., 1989; Hahnemann et al., 1992; Viitala et al., 2001; Abu-Bakar et al., 2004). The increased CYP2A5 levels are also associated in various pathophysiological conditions such as hepatitis, hepatoma, malaria, fatty liver, and fasting (Kirby et al., 1994b; Chomarat et al., 1997; Sipowicz et al., 1997; Bauer et al., 2004; De-Oliveira et al., 2006, 2010; Fisher et al., 2009). Previous studies have shown that the regulation of CYP2A5 in these conditions involves many cellular pathways, but a commonality exists that CYP2A5 may play a role in protection against oxidative stress induced by these conditions. Furthermore, bilirubin and heme have been identified as the first endogenous substrates for CYP2A5 and CYP2A6 (Abu-Bakar et al., 2011, 2012; Lämsä et al., 2012).

Bilirubin (BR) is the end product of heme catabolism, and heme is found in hemoglobin or other hemoproteins such as cytochromes, catalase, and a small pool of free heme (Roy-Chowdhury et al., 2007). BR has dual physiological characteristics in that it has antioxidative properties at low concentrations ranging from $0.01-10 \mu \mathrm{M}$ (Stocker et al., 1987; Neuzil and Stocker, 1994; Dailly et al., 1998; Hatfield and Barclay, 2004), and cytotoxic properties in many cell types and intracellular organelles at higher 
concentrations (>20 $\mu \mathrm{M})$ (Roy-Chowdhury et al., 2007). BR is generally metabolized by a single uridine diphosphoglucuronate glucuronosyltransferase isoform, UGT1A1 via the glucuronidation reaction of phase II drug metabolism (Bosma et al., 1994). Therefore, in conditions in which the function of UGT1A1 is compromised or BR levels are drastically increased due to jaundice, liver disease, and genetic disorders, the prolonged exposure and accumulation of BR can lead to serious cell damage or even death in various cell types (Dennery et al., 1995; Bhutani et al., 1999; McDonagh, 2010).

Cellular injury by BR starts at the cell membrane level, which is followed by the interaction with the intracellular membranes that surround various organelles, particularly mitochondria and the endoplasmic reticulum (ER). Previous studies have shown that BR exposure can induce alterations in the membrane content of cholesterol and lipids in erythrocytes (Brito et al., 2002). BR has also been shown to disrupt the membrane receptors, transporters and enzymes that play key roles in various functions such as endocytosis, glutamate uptake, and maintaining membrane potentials (Mayor et al., 1986; Silva et al., 2001; Brito et al., 2006, 2007). Upon the entrance of BR, its cytotoxic effects have been reported in intracellular organelles, particularly in mitochondria and the ER.

Many reports have shown BR disrupts the functions of mitochondria at the membrane level and also induce apoptosis via both intrinsic and extrinsic apoptotic pathway (Rodrigues et al., 2002; Seubert et al., 2002; Ostrow et al., 2004; Vaz et al., 2011; Brites and Brito, 2012). BR has been also reported to induce expression of regulatory genes and proteins for unfolded protein response (UPR), which is a key regulatory defense mechanism against ER stress (Calligaris et al., 2009; Oakes and Bend, 2010). Increased intracellular calcium $\left(\mathrm{iCa}^{2+}\right)$, reactive oxygen species (ROS), and 
activities of pro-apoptotic protease caspase-3 has been also observed with BR treatment, suggesting that BR causes ER stress (Brito et al., 2006; Gao et al., 2011). Furthermore, many reports show that the cytotoxic effects of BR extend down to nucleus. Previous studies have demonstrated that BR induces DNA damage and disrupt cell growth via DNA oxidation and activation of extracellular signal-regulated kinase 1 and 2 (ERK1/2) (Ollinger et al., 2007; Nguyen et al., 2008; Deganuto et al., 2010).

Although the cytotoxic effects of BR involve numerous cell signaling pathways and molecules, the common mechanism that leads to apoptosis and/or necrosis of an subjected cell appears to be, in part, by production of ROS and reactive nitrogen species (RNS) (Brites and Brito, 2012). In addition, most studies have looked at nervous tissue for cytotoxic effects of BR for its implication in neonatal hyperbilirubinemia, but recent studies suggest liver is also significantly affected by BR (Seubert et al., 2002; Oakes and Bend, 2005, 2010).

Furthermore, Abu-Bakar et al. (2011) suggested an interesting theory that CYP2A5 plays a major role in BR clearance as an alternative mechanism to BR conjugation by UGT1A1 (Abu-Bakar et al., 2011). Abu-Bakar et al. (2011) demonstrated that BR treatment in mouse primary hepatocytes increased CYP2A5 protein and its activity levels, and that CYP2A5 protein is stabilized by BR (Abu-Bakar et al., 2011). Abu-Bakar et al. (2011) also established a recombinant yeast system overexpressing CYP2A5 and demonstrated CYP2A5 metabolizes BR into biliverdin as the main metabolite, suggesting that CYP2A5 is an inducible BR oxidase that it prevents the wasting of BR via glucuronidation and accumulation of BR in pro-oxidant levels (Abu-Bakar et al., 2011). Later, Abu-Bakar et al. (2012) further confirmed this notion in CYP2A6 by using the 
same yeast expression system (Abu-Bakar et al., 2012). However, the role of CYP2A5 in BR metabolism needs to be confirmed in vivo model, and its regulation by BR also needs to be further investigated, as recent reports shows evidences that CYP2A5 may also be transcriptionally regulated by BR.

Cyp2a5 is regulated in a complex and unique manner. To study the gene regulation of Cyp2a5, a reporter construct containing the Cyp2a5 5' upstream promoter region from -3033 to $+10 \mathrm{bp}$ has been constructed (Ulvila et al., 2004). Since then, a number of transcription factors for Cyp $2 a 5$ and their response elements in the Cyp2a5 promoter region have been identified. The transcription factors identified to date, such as aryl hydrocarbon receptor (AhR), aryl hydrocarbon receptor nuclear translocator (ARNT), upstream stimulatory factors (USF-1 and USF-2), hepatic nuclear facor-4-alpha (HNF4a), nuclear factor I (NF-I), constitutive androstane receptor (CAR), and nuclear factorE2 p45-related factor $2(\mathrm{Nrf} 2)$ have been shown to play an important role in cellular stress and the immune response, oxidative stress and detoxification of xenobiotics, cell cycle and proliferation, and lipid and glucose metabolism (Cai et al., 2002; Maglich et al., 2002; Abu-Bakar et al., 2004; Ulvila et al., 2004; Abu-bakar et al., 2007; Arpiainen et al., 2007, 2008; Kirby et al., 2011).

$\mathrm{Nrf} 2$ is the transcription factor that regulates the expression of numerous cytoprotective genes in response to oxidative stress and xenobiotic challenges. The target genes are specifically involved in glutathione synthesis, ROS clearance, xenobiotic metabolism, and drug transport (Itoh et al., 1999; Kobayashi et al., 2004). Nrf2 has been characterized to tightly regulate constitutive and inducible expression of Cyp2a5 in response to oxidative stress caused by heavy metals or nitric oxide (Abu-Bakar et al., 
2004; Dhakshinamoorthy and Porter, 2004; Purdom-dickinson et al., 2007; Lämsä et al., 2010). Furthermore, recent work by Lämsä et al. showed that heme, the parent compound of BR, regulates Cyp2a5 expression via Nrf2 activation (Lämsä et al., 2012). These findings suggest $\mathrm{Nrf} 2$ may be involved in BR induction of Cyp2a5.

Therefore, to confirm the role of CYP2A5 in BR metabolism and to further investigate its regulatory mechanism in response to BR, we hypothesized that CYP2A5 overexpression can protect hepatocytes against excessive BR and CYP2A5 is transcriptionally regulated by BR via activation of Nrf2. The first objective of this study was to examine the effects of excessive BR in CYP2A5 mRNA and protein expression, and investigate the regulatory mechanisms. The second objective of this study was to investigate if overexpression of CYP2A5 could protect cells against BR toxicity. Lastly, the third objective of this study was to confirm that cytoprotective role of CYP2A5 in BR toxicity is due to its direct clearance of BR. Our results indicate that BR upregulates CYP2A5 mRNA and protein expression and that this induction requires Nrf2 activation. Furthermore, overexpression of CYP2A5 directly degrades BR and partially blocks BRinduced apoptosis. 


\section{LITERATURE REVIEW}

Cytochrome P450 enzyme

Cytochrome P450s (CYPs) enzymes are a superfamily of oxidative heme-thiolate enzymes found in nearly all species. These enzymes are responsible for metabolism of a wide range of drugs and xenobiotics, and are primarily involved in phase I reaction of drug metabolism, which includes dehydrogenation/hydrogenation, oxidation/reduction, hydrolysis, and monooxygenation (Meyer, 1996). The phase I reactions catalyzed by CYPs converts drugs or potentially harmful xenobiotics into more hydrophilic compounds, facilitating their excretion from the body (Testa and Kramer, 2007). However, biologically neutral parent substrates can be bioactivated to form more cytotoxic, mutagenic, or carcinogenic products (Porter and Coon, 1991; Guengerich, 2001). In mammals, CYPs have been found in the liver, brain, kidney, and many other tissues, and are primarily located in the endoplasmic reticulum, mitochondria, and plasma membrane compartments (Sangar et al., 2010).

\section{Origin and Nomenclature}

Evidence relating to the existence of CYPs was first reported in 1955 by Axelord and Brodie et al. where it was demonstrated that endoplasmic reticulum of the liver was able to oxidize xenobiotics (Axelord, 1955; Brodie et al., 1955). In 1958, Garfinkel and Klingenberg discovered a $\mathrm{CO}$ binding pigment in rat liver microsomes which had an absorption spectrum with a peak at $450 \mathrm{~nm}$ (Garfinkel, 1958; Klingenberg, 2003). This was soon demonstrated to be a hemoprotein of the b-type class by Omura and Sato in 
1964, and proposed the name Cytochrome P450 after the strong feature of absorption spectrum of hemoprotein at $450 \mathrm{~nm}$ (Omura and Sato, 1964a, 1964b).

CYPs are classified by their sequence homology, gene organization, and chromosomal location. Generally, genes within the same family have $40 \%$ sequence identity and are denoted by a number (e.g. CYP2). The members of the same subfamily, denoted by a letter (e.g. CYP2A), have greater than 55\% sequence identity, and are also clustered in the genome. Finally, different isoenzymes and various allele within the subfamily are denoted by numbers (e.g. CYP2A6*4) (Nelson et al., 1996). Up to date, more than 11,200 sequences have been identified in over 970 CYP families in animals, plants, and microorganisms (Cytochrome P450 homepage; drnelson.uthsc.edu/CytochromeP450.html, September 2012). CYP families 1-4 are typically classified as xenobiotic- and fatty acid-metabolizing CYPs, but the majority of them also have known endogenous substrates that can regulate their expression and activity (Guengerich 2008; Omiecinski, Remmel, and Hosagrahara 1999).

\section{Cytochrome P450 2A5}

Cytochrome P450 2A5 (CYP2A5) is a murine orthologue of the human nicotinemetabolizing enzyme CYP2A6 and is located primarily in the endoplasmic reticulum (ER) of the liver and olfactory mucosa of mice (Juvonen et al., 1985; Su et al., 1996; Piras et al., 2003; Sangar et al., 2010). CYP2A5 can be also found in mitochondrial membranes and the recent study suggests that mitochondrial CYP2A5 may play a role in the oxidative stress response (Honkakoski et al., 1988; Genter et al., 2006). CYP2A5, to date, has been extensively studied for its unique regulation. CYP2A5 is upregulated following 
exposure to chemical hepatoxins and during pathophysiological conditions in which the levels of most CYPs are either unchanged or decreased (Juvonen et al., 1985; Camus et al., 1996; Kojo et al., 1998; Kirby et al., 2011). CYP2A5 was first identified as the catalyst for the 7-hydroxylation of coumarin and the deethylation of 7-ethoxycoumarin, and was later associated with the metabolism and activation of many other xenobiotics (Juvonen, Shkumatov, \& Lang, 1988). Gender differences exist as well for CYP2A5 activity levels. CYP2A5 activities are significantly higher in female mice of DBA/2, 129/J, and CBA/Ca strains, but not in A/K, AKR, BALB/c, C3H/He, and C57BL/6 strains (Iersel et al., 1994).

Substrates and Inducers for CYP2A5

After CYP2A5 was first identified as the catalyst for coumarin and 7ethoxycoumarin metabolism, a wide range of substrates have been identified. The substrates include nitrosamines, aflatoxin B1, the tobacco-specific carcinogen 4(methylnitrosamino)-1-(3-pyridyl)-1-butanone (NNK), nicotine, 3-methylindole, methimazole, and acetaminophen (Juvonen et al., 1988; Camus et al., 1993; Kirby et al., 1994a, 1996; Pelkonen et al., 1994; Genter et al., 1998; Felicia et al., 2000; Siu et al., 2006; Xie et al., 2011; Zhou et al., 2012). A wide range of atypical CYP inducers of CYP2A5 has also been identified. Chemical inducers of CYP2A5 have varying structures, and include hepatotoxins, heavy metals, hormones, and porphyrinogenic compounds as shown in Table 1. Furthermore, recently Abu-Bakar et al. $(2011,2012)$ identified bilirubin (BR) as the first endogenous substrate for CYP2A5 and CYP2A6 using recombinant yeast system overexpressing CYP2A5 (Abu-Bakar et al., 2005, 2011, 2012). 
Abu-Bakar et al. (2011) suggested CYP2A5 is potentially an inducible "bilirubin oxidase" where bilirubin post-translationally stabilizes CYP2A5 protein (Abu-Bakar et al., 2011).

Pathophysiological states associated with CYP2A5

Increased CYP2A5 levels are also associated with various pathophysiological states as shown in Table 1.2. The mechanism of the unique regulation of Cyp2a5 during these conditions is unclear and remains to be investigated. The one demonstrated mechanism that is common in these conditions is, in part, oxidative stress (Kirby et al., 1994b; Chomarat et al., 1997; Nebert et al., 2000; Cheung et al., 2003; Gilmore et al., 2003; Gilmore and Kirby, 2004; Su and Ding, 2004; Weng et al., 2005; Chen and Siddiqui, 2007; Fisher et al., 2009; De-Oliveira et al., 2010). Furthermore, these conditions appear to be associated with increased serum bilirubin levels (Bonacini, 2004; Malaguarnera et al., 2005; Richardson et al., 2006b; Hansen, 2010). 
Table 1.1 Chemical inducers of CYP2A5

\begin{tabular}{|c|c|c|c|}
\hline Type & Name & Use & Reference \\
\hline \multirow[t]{6}{*}{ Hepatotoxin } & $\begin{array}{l}\text { Carbon } \\
\text { tetrachloride }\end{array}$ & $\begin{array}{l}\text { Fire extinguisher and cleaning } \\
\text { agent }\end{array}$ & (Pellinen et al., 1993) \\
\hline & Chloroform & Anesthetic/Teflon & (Camus et al., 1996) \\
\hline & Cocaine & Topical anesthetic & $\begin{array}{l}\text { (Pellinen et al., 1994a, } \\
\text { 1994b) }\end{array}$ \\
\hline & Ethanol & Fuel, beverage, and antiseptic & (Lu et al., 2010) \\
\hline & Phenobarbital & Barbiturate and anticonvulsant & $\begin{array}{l}\text { (Hahnemann et al., 1992; } \\
\text { Salonpää et al., 1994) }\end{array}$ \\
\hline & Pyrazole & Precursor for various medicines & $\begin{array}{l}\text { (Juvonen et al., 1985; } \\
\text { Nichols and Kirby, 2008) }\end{array}$ \\
\hline \multirow[t]{6}{*}{ Heavy metals } & Cobalt & Metal in alloys & $\begin{array}{l}\text { (Kocer et al., 1991; } \\
\text { Hahnemann et al., 1992) }\end{array}$ \\
\hline & Cerium & Additives to fuels & (Arvela et al., 1991) \\
\hline & Cadmium & Batteries & (Abu-Bakar et al., 2004) \\
\hline & Indium & $\begin{array}{l}\text { Fusible alloy, solders, and } \\
\text { electronics }\end{array}$ & (Mangoura et al., 1989) \\
\hline & Lead & $\begin{array}{l}\text { Building construction, fusible } \\
\text { alloys, batteries }\end{array}$ & (Lämsä et al., 2010) \\
\hline & Methylmercury & No use (environmental toxicant) & (Lämsä et al., 2010) \\
\hline \multirow{6}{*}{$\begin{array}{l}\text { Porphyrinogenic } \\
\text { compounds }\end{array}$} & Acifluorfen & Herbicide & (Salonpää et al., 1997) \\
\hline & Aminotriazole & $\begin{array}{l}\text { Herbicide and application in } \\
\text { microbiology }\end{array}$ & (Salonpää et al., 1995) \\
\hline & Griseofulvin & Antifungal drug & (Salonpää et al., 1995) \\
\hline & Thioacetamide & No use (carcinogen) & (Salonpää et al., 1995) \\
\hline & Heme & Prosthetic group for porphyrin & (Lämsä et al., 2012) \\
\hline & Bilirubin & End product of heme catabolism & (Abu-Bakar et al., 2011) \\
\hline \multirow[t]{4}{*}{ cAMP modifier } & Glucagon & $\begin{array}{l}\text { Hormone from pancreas for } \\
\text { increasing blood glucose }\end{array}$ & (Viitala et al., 2001) \\
\hline & Forskolin & Activator of adenylyl cyclase & (Viitala et al., 2001) \\
\hline & Isoproterenol & $\beta$-adrenergic agonist & (Viitala et al., 2001) \\
\hline & Sp-cAMP & $\begin{array}{l}\text { Specific activator of cAMP- } \\
\text { dependent protein kinase }\end{array}$ & (Viitala et al., 2001) \\
\hline \multirow[t]{5}{*}{ Xenobiotics } & $\begin{array}{l}\text { 1,4-Bis-[2-(3,5- } \\
\text { dichloropyridylox } \\
\text { y)]benzene } \\
\text { (TCPOBOP) }\end{array}$ & $\begin{array}{l}\text { Constitutive androstane receptor } \\
\text { (CAR) ligand }\end{array}$ & (Cai et al., 2002) \\
\hline & $\begin{array}{l}\text { Buthionine } \\
\text { sulfoximine }\end{array}$ & $\begin{array}{l}\text { Drug used in chemotherapy to } \\
\text { reduce levels of glutathione }\end{array}$ & (Gilmore et al., 2003) \\
\hline & $\begin{array}{l}\text { pregnenolone } \\
16 a-c a r b o n i t r i l e \\
(\mathrm{PCN})\end{array}$ & $\begin{array}{l}\text { Pregnane } \mathrm{X} \text { receptor }(\mathrm{PXR}) \\
\text { agonist or antiglucocorticoid }\end{array}$ & (Cai et al., 2002) \\
\hline & Rifampicin & Bactericidal antibiotics & (Donato et al., 2000) \\
\hline & $\begin{array}{l}\text { Trans-4,5- } \\
\text { dihydroxy-1,2- } \\
\text { dithiane (DTTox) }\end{array}$ & $\begin{array}{l}\text { Intramolecular disulfide form of } \\
\text { dithiothreitol; reducing agent }\end{array}$ & (Gilmore and Kirby, 2004) \\
\hline
\end{tabular}


Table 1.2. Pathophysiological states associated with increased CYP2A5 level

\begin{tabular}{ll}
\hline \multicolumn{1}{c}{ Pathophysiological states } & \multicolumn{1}{c}{ Reference } \\
\hline Bacterial hepatitis by Helicobacter hepaticus & (Chomarat et al., 1997; Sipowicz et al., 1997) \\
\hline Bacterial infection by Citrobacter rodentium & (Richardson et al., 2006a) \\
\hline Fasting & (Bauer et al., 2004) \\
\hline Hepatitis B antigen - Fulminant hepatitis & (Chemin et al., 1996) \\
\hline Hepatitis B virus & (Kirby et al., 1994a) \\
\hline Hepatoma & (Jounaïdi et al., 1994) \\
\hline Malaria & (De-Oliveira et al., 2006, 2010) \\
\hline Nonalcoholic Fatty Liver & (Fisher et al., 2009) \\
\hline Trematode infection by Ouke Fasciola hepatica & (Montero et al., 1999) \\
\hline
\end{tabular}

\section{Bilirubin}

Bilirubin (BR) is the end product of heme catabolism, and heme is found in hemoglobin or other hemoproteins such as cytochromes, catalase, and a small pool of unbound free heme (Roy-Chowdhury et al., 2007). BR consists of a tetrapyrrole (Figure D1). In heme, however, the four pyrrole rings are connected into a larger ring, called a porphyrin ring (Bonnett, Davies, \& Hursthouse, 1976; Grandchamp, Bissell, Licko, \& Schmid, 1981; Figure D1). BR is formed through a series of oxidation-reduction reactions. The microsomal heme oxygenase $(\mathrm{HO})$ enzymes catalyze the oxidation of heme, leading to opening of the tetrapyrrole ring and release of the iron molecule (Tenhunen et al., 1969). The resulting product, biliverdin is then subsequently reduced to BR by cytosolic biliverdin reductase (BVR) (Tenhunen et al., 1970). 
<smiles>c1cc[nH]c1</smiles>

Pyrrole<smiles>CN1CCC[C@H]1c1cccnc1</smiles>

Nicotine

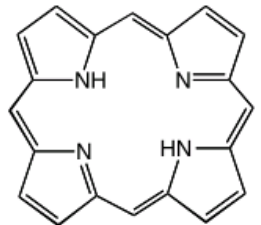

Porphyrin<smiles>c1cn[nH]c1</smiles>

Pyrazole<smiles>c1cc[nH]c1</smiles>

Imidazole<smiles>C1CCNC1</smiles><smiles>c1ccncc1</smiles>

Pyrrolidine Pyridine<smiles>Cc1c[nH]c2ccccc12</smiles>

3-methylindole

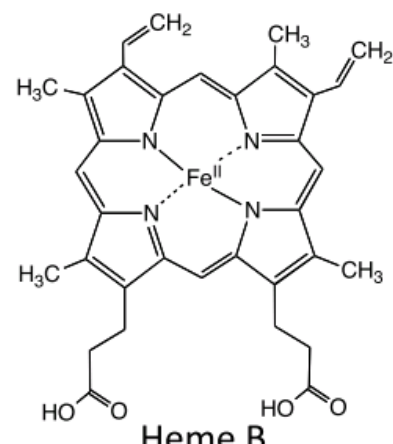<smiles>c1ncc2nc[nH]c2n1</smiles>

Purine

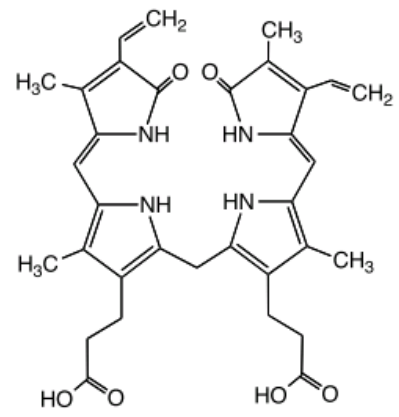

Bilirubin

Figure D1. Chemical structures of some nitrogen heterocycle substrates, inducers or inhibitors of CYP2A enzymes (Kirby et al., 2011).

\section{Bilirubin metabolism}

Erythrocytes are destroyed in the spleen when they get old or damaged; this releases hemoglobin, which is broken down into heme. The heme is then converted into unconjugated BR in the reticuloendothelial cells of the spleen (Tenhunen et al., 1969, 1970). The unconjugated BR has a low water solubility, which therefore requires binding to albumin in order to travel to the liver via bile duct (Roy-Chowdhury et al., 2007). Unconjugated BR is dissociated from albumin at the sinusoidal surface of the hepatocyte and is taken up by the hepatocytes by facilitated diffusion (Roy-Chowdhury et al., 2007). 
A member of the organic anion transporter protein family, termed OATP2/8/C, has been suggested to mediate BR uptake, but it still remains questionable and requires confirmation (Briz et al., 2003; Wang et al., 2003b; Steeg et al., 2010; de Graaf et al., 2011). After entering the hepatocytes, BR binds to glutathione-S-transferases (GSTs), a major group of detoxification enzymes (Levi et al., 1969; Pickett, 1989; Strange et al., 2001). BR, however, is not a substrate for glutathione conjugation. The binding to GSTs reduces the efflux of BR from hepatocytes increasing its net uptake (Kamisaka et al., 1975; Wolkoff et al., 1978, 2012). BR is then converted into mono- and di-glucuronide predominantly by a single uridine diphosphoglucuronate glucuronosyltransferase (UGTs) isoform, UGT1A1 (Bosma et al., 1994). This converts water-insoluble unconjugated BR to be transformed into a more polar form that can be excreted in the bile and feces (RoyChowdhury et al., 2007).

Dual characteristics of bilirubin (BR)

BR is an interesting molecule for its cytoprotective potential at physiological levels and its cytotoxic characteristics at supraphysiological levels (Stocker et al., 1987; Roy-Chowdhury et al., 2007; Brites and Brito, 2012). Previous studies showed that BR has an antioxidant property that is equivalent to that of $\alpha$-tocopherol in potency to inhibit lipid peroxidation. Antioxidative properties of BR have been reported at low concentrations ranging from $0.01-10 \mu \mathrm{M}$ (Stocker et al., 1987; Neuzil and Stocker, 1994; Dailly et al., 1998; Hatfield and Barclay, 2004). The antioxidative property of BR has been shown to be beneficial in protection against a various disease states including vascular, cardiovascular, and neural diseases (Doré et al., 1999; Ollinger et al., 2005; 
Gazzin et al., 2012). Furthermore BR has been also implicated in hepatic protection against bile acid-induced apoptosis in rat hepatocytes, and hyperoxia in neonate Gunn rats (Dennery et al., 1995; Granato et al., 2003).

In contrast, $\mathrm{BR}$ at higher concentrations $(>20 \mu \mathrm{M})$ has been shown to be toxic to many cell type and intracellular organelles (Roy-Chowdhury et al., 2007). High BR concentration is observed in many pathobiological conditions, including biliary obstruction, neonatal jaundice, liver diseases, or some genetic disorders such as Gilbert's syndrome. In these conditions, plasma BR levels can be significantly increased ( $>300$ $\mu \mathrm{M})$ above its homeostatic level $(\sim 20 \mu \mathrm{M})$ (Dennery et al., 1995; Bhutani et al., 1999). In such circumstances, the prolonged exposure and accumulation of BR can lead to serious cell damage or even death (McDonagh, 2010). However, the molecular mechanisms underlying or contributing to BR toxicity in various cell types or tissues are not completely understood. Previous studies have reported that BR toxicity is mediated by disruption of several cellular functions rather than a single signaling pathway, suggesting BR toxicity involves complex mechanisms (Roy-Chowdhury et al., 2007; Brites and Brito, 2012).

\section{Bilirubin toxicity}

Cellular injury by BR starts at the cell membrane level, which is followed by interaction with the intracellular membranes that surround various organelles. Previous studies demonstrate that BR exposure to erythrocytes induce alterations in the membrane content of cholesterol and all the classes of phospholipids, which may facilitate hemolysis and erythrophagocytosis (Brito et al., 2002). In neurons, BR exposure impairs 
endocytosis, glutamate uptake, and alterations in membrane potential (Mayor et al., 1986; Silva et al., 2001; Brito et al., 2006). Furthermore, disruption in efficiency of membrane receptors, transporters, and enzymes in neurons have also been reported as toxic effects of BR (Brito et al., 2006, 2007). The mechanism of these toxic effects has been reported to be through production of reactive oxygen species (ROS) resulting in protein oxidation, and lipid peroxidation (Brito et al., 2004, 2008a, 2008b).

Cytotoxic effects of BR have been also observed in intracellular organelles. Many reports suggest mitochondria are particularly vulnerable to toxic effects of BR. BR causes mitochondrial dysfunction with collapse of inner mitochondrial membrane potential, a diminished activity of cytochrome c oxidase, and the release of cytochrome c to the cytosol, which is an initiation of apoptosis via mitochondrial intrinsic pathway (Rodrigues et al., 2002; Ostrow et al., 2004; Brites and Brito, 2012). BR may also induce apoptosis via mitochondrial extrinsic pathway by activation of caspase-8, suggesting that BR interaction with a death receptors (e.g. Fas) may be involved (Seubert et al., 2002; Vaz et al., 2011). However, BR-induced apoptosis via extrinsic pathway remains to be confirmed as the induction may be cell type-specific (Keshavan et al., 2004). BRinduced mitochondrial apoptotic pathway is also the result of production of lipid peroxides, hydrogen peroxide, and hydroxyl radical, as well as a decrease in glutathione content and reduction of the mitochondrial membrane (Kumar et al., 2008; Brites and Brito, 2012). The increased production of ROS by BR has been observed in various cell types including HeLa, mouse embryonic fibroblasts, Hepa 1c1c7, astrocytes, and neurons (Seubert et al., 2002; Cesaratto et al., 2007; Brito et al., 2008a, 2008b). 
Another mechanism of cell damage by bilirubin involves ER stress. The ER regulates the synthesis, folding and trafficking of newly formed secretory and membrane proteins, cellular responses to stress, and intracellular calcium $\left(\mathrm{iCa}^{2+}\right)$ (Ron and Walter, 2007). ER stress refers to any disruption that compromises protein folding and other functions of the ER. During ER stress, the unfolded protein response (UPR) is activated in the cell, which involves reducing the load of unfolded proteins through global attenuation of protein synthesis and translocation and by upregulating chaperones (Kaufman, 2002). BR has been reported to induce the expression of key regulatory genes and proteins required for the UPR (Calligaris et al., 2009; Oakes and Bend, 2010). Elevated $\mathrm{iCa}^{2+}$ along with ROS production has been observed in synaptosomes treated with BR (Brito et al., 2006). Increased $\mathrm{iCa}^{2+}$ disrupts intracellular homeostasis and may further produce more ROS and induce ER stress (Brites and Brito, 2012). A recent study also demonstrated that neurotoxic effects of BR in a hyperbilirubinemic mouse model that was associated with increased $\mathrm{iCa}^{2+}$ and activities of proapoptotic caspase-3 (Gao et al., 2011).

The cytotoxic effects of BR in various cell types as noted above also extend to the nucleus. BR-induced oxidative stress causes DNA damage and cell growth reduction in a human neuroblastoma cell line thereby impairing S-phase cell cycle progression and triggering apoptosis (Deganuto et al., 2010). It has also been reported that BR treatment induces cell cycle arrest by activation of extracellular signal-regulated kinase 1 and 2 (ERK 1/2) in the human colon cancer cell line (HRT-18), and the genes linked to the cell cycle are significantly repressed while genes linked to the inhibition of cellular kinases are induced in Ugt-null mice (Ollinger et al., 2007; Nguyen et al., 2008). 
The cytotoxic effects of BR, as noted above, involve various cell signaling pathways and molecules. The consequences of high levels of BR can lead to apoptosis and/or necrosis of affected cell, and the production of ROS and reactive nitrogen species (RNS) appears to be the common mechanism involved, in part, for cell death (Brites and Brito, 2012). In addition, most studies have looked at nervous tissue for cytotoxic effects of BR, but recent studies suggest that the liver is also significantly affected by BR (Seubert et al., 2002; Oakes and Bend, 2005, 2010). Furthermore, Abu-bakar et al. (2011) demonstrated an alternative pathway for bilirubin clearance by CYP2A5, suggesting the need for further investigation of BR metabolism in liver (Abu-Bakar et al., 2011).

CYP2A5 in bilirubin metabolism

Evidence for the possible involvement of CYP2A5 in BR metabolism was first reported by Berry et al. (1972) that a fraction of BR is excreted as hydroxylated products in jaundiced Gunn rats, by the action of cytochrome P450 microsomes (Berryl et al., 1972; Kapitulnik and Ostrow, 1978). Later, Matteis et al. (1989) established an in vitro BR disappearance activity assay using the microsomal fraction of liver homogenates after treatment with powerful inducer of CYPs, 2,3,7,8-tetrachlorodibenzo-p-dioxin (TCDD) in vivo (Matteis et al., 1989). This approach was further utilized to identify specific isoforms of CYPs involved in BR degradation. Studies using TCDD and Cypla2-null mutant mice, suggested both Cypla1 and Cypla2 play a role in BR degradation (Matteis et al., 1991; Zaccaro et al., 2001).

However, Cyp2a5 has been the most extensively studied CYPs to date and the direct involvement of CYP2A5 in BR degradation has been demonstrated by Abu-Bakar et al. 
(Abu-Bakar et al., 2005). In their study, treatment of DBA/2J mice with Cadmium Chloride $\left(\mathrm{CdCl}_{2}\right)$ in vivo induced Cyp2a5 and HO-1, an enzyme that catalyzes the ratelimiting step in heme catabolism, and this in turn, increased microsomal BR degradation activity (Abu-Bakar et al., 2005). They also showed that Cyp $1 a 2$ was down-regulated by the $\mathrm{CdCl}_{2}$ and microsomal $\mathrm{COH}$ activity was competitively inhibited by $\mathrm{BR}$. This report provided indirect evidence that CYP2A5 may play a major role in BR clearance during the liver injury where BR levels are elevated following the induction of HO-1 (AbuBakar et al., 2005).

Recently, Abu-Baker et al. (2011) established a recombinant yeast system overexpressing CYP2A5, and identified oxidative metabolites of BR using a highperformance liquid chromatography/electrospray ionization mass spectrometry (AbuBakar et al., 2011). The report shows that recombinant yeast microsomes expressing CYP2A5 oxidize BR to biliverdin as the main metabolite, and to three other smaller products (Abu-Bakar et al., 2011). Aside from enzymatic degradation of BR, previous reports have showed BR degradation can also occur via interaction with reactive free radicals (Reed et al., 1985; Joshi et al., 1995). The BR oxidative metabolite profiles however, are different in chemical oxidation of BR. In chemical oxidation the smaller products are the main metabolites, suggesting the CYP2A5-mediated BR oxidation is selective, towards biliverdin production (Matteis et al., 2006; Abu-Bakar et al., 2011).

Abu-Bakar et al. (2011) further demonstrated that BR treatment in mouse primary hepatocytes increased the CYP2A5 protein and activity levels with no effects on mRNA expression. In addition, they also suggested CYP2A5 induction by BR was mediated by protein stabilization, using a protein synthesis inhibitor, cycloheximide $(\mathrm{CHX})(\mathrm{Abu}-$ 
Bakar et al., 2011). Abu-Bakar et al. (2011) suggests CYP2A5 is an inducible BR oxidase, and its major role is to prevent wasting of BR via glucuronidation and accumulation of BR in pro-oxidant levels, by maintaining the cycle of BR conversion into biliverdin, and subsequent recovery of BR by biliverdin reductase (Abu-Bakar et al., 2011). Later, the role of CYP2A6 human orthologoue of CYP2A5 in BR metabolism was confirmed in the recombinant yeast microsomes expressing CYP2A6, hurman orthologue of CYP2A5 (Abu-Bakar et al., 2012). However, the mechanism of CYP2A5 induction by BR remains to be further investigated.

Transcriptional regulation of Cyp2a5

CYP2A5 is regulated in a complex and unique manner. Ulvila et al. (2004) first cloned the Cyp2a5 5' upstream promoter region from -3033 to +10 bp into a luciferase (Luc) reporter construct and studied the promoter activity in mouse primary hepatocytes by deletion analysis (Ulvila et al., 2004). Since then, several transcription factors and cofactors have been identified for the constitutive and inducible expression of the Cyp2a5 gene (Kirby et al., 2011). The functional response elements have been also identified in the Cyp2a 5 promoter region. To date, transcription factors that bind to these response elements include the aryl hydrocarbon receptor (Ahr), aryl hydrocarbon receptor nuclear translocator (ARNT), upstream stimulatory factors (USF-1 and USF-2), hepatic nuclear factor-4-alpha (HNF-4 $\alpha$ ), nuclear factor I (NF-I), constitutive androstane receptor (CAR), pregnane $\mathrm{X}$ receptor (PXR), peroxisome proliferator-activated receptor $\gamma$ coactivator (PGC-1 $\alpha$ ), and nuclear factor-E2 p45-related factor 2 (Nrf2) (Cai et al., 2002; Maglich et 
al., 2002; Abu-Bakar et al., 2004; Ulvila et al., 2004; Abu-bakar et al., 2007; Arpiainen et al., 2007, 2008).

$\mathrm{AhR}$ is a ligand-activated transcription factor involved in the protection against oxidative stress and detoxification of xenobiotics. Previous studies show that Ahr directly regulates the Nrf2 antioxidant response pathway and also upregulates CYP1A1 and CYP1A2, which are xenobiotic detoxifying enzymes involved in oxidative stress response, cell cycle control, and apoptosis (Nebert et al., 2000; Miao et al., 2005). The AhR translocates from the cytoplasm into the nucleus upon its activation and forms a heterodimer complex with the AhR nuclear translocator (ARNT) (Hoffman et al., 1991). Arpiainen et al. (2005) identified a putative AhR response element (XRE) in the Cyp2a5 promoter at the position -2514 to 2492 , then also demonstrated that the AHR/ARNT complex binds to XRE when stimulated with AhR ligand, TCDD (Arpiainen et al., 2005). Later, Arpiainen et al. (2007) further demonstrated that ARNT can homodimerize and bind to the E-box which is located at position -2403 to -2398 in the Cyp2a5 promoter (Arpiainen et al., 2007).

USF-1 and USF-2a are basic-Helix-Loop-Leucine Zipper transcription factors involved in response to stress, and the immune response, cell cycle and proliferation, and lipid and glucose metabolism (Corre and Galibert, 2005). Arpiainen et al. (2007) showed that USF-1 and USF-2a also bind to the E-box, but requires HNF-4 $\alpha$ to activate Cyp $2 a 5$ promoter, while ARNT transactivation was independent of HNF-4 $\alpha$ (Arpiainen et al., 2007).

HNF-4 $\alpha$ is one of the liver-enriched transcription factors that plays an important role in liver-specific gene regulation (Schrem et al., 2002). HNF-4 $\alpha$ constitutively regulates 
genes in a numerous important metabolic pathways involved in glucose, fatty acid, cholesterol metabolism, drug metabolism, and blood coagulation (Sladek, 1993; Chen et al., 1994; Stoffel and Duncan, 1997; Schrem et al., 2002; Onzalez, 2008). HNF-4 $\alpha$ was originally considered to be an orphan receptor, but recent studies showed that linoleic acid selectively binds to active site of HNF-4 $\alpha$ (Wisely et al., 2002; Yuan et al., 2009). However, the ligand occupancy appears to have no significant effect on HNF-4 $\alpha$ transcriptional activity and HNF-4 $\alpha$ is transcriptionally active even in the absence of its ligand (Yuan et al., 2009). Ulvila et al. (2004) demonstrated that HNF-4 $\alpha$ regulates constitutive expression of Cyp2a5 and also identified its binding site in the Cyp2a5 promoter at position -63 to -47 (Ulvila et al., 2004). However, the promoter region -63 to +10 produced very little transcriptional activity, while mutation of the promoter at positions -271 to -3033 strongly decreased transcriptional activity by HNF-4 $\alpha$ (Ulvila et al., 2004). In addition, PGC- $1 \alpha$ has been identified as a cofactor for HNF- $4 \alpha$-mediated transcriptional activation of Cyp2a5 in response to fasting, glucagon, and cyclic AMP (cAMP) (Arpiainen et al., 2008).

Transcription factor NF-I is involved in the initiation of transcription and DNA replication. NF-I has a conserved N-terminal region that mediates DNA binding and dimerization (Mermod et al., 1989). Ulvila et al. (2004) also the identified a binding site for NF-I in the Cyp2a5 promoter at -132 to -107 , and demonstrated that NF-I is responsible for constitutive expression of Cyp2a5 together with HNF-4 $\alpha$ (Ulvila et al., 2004).

CAR and PXR are nuclear receptors that regulate genes involved in important physiological pathways including xenobiotic, glucose, and fatty acid metabolism 
(Maglich et al., 2002; Moreau et al., 2007; Konno et al., 2008). CAR and PXR have been also shown to modulate the immune response and the genes involved in lipid and cholesterol synthesis (Moreau et al., 2007; Roth et al., 2008). No definite physical ligand have been identified for both CAR and PXR, but previous reports show they exhibit the ability to bind multiple ligands (Tzameli et al., 2000; Sueyoshi and Negishi, 2001; Willson and Kliewer, 2002; Maglich et al., 2003). Upon activation, CAR and PXR translocate to the nucleus and heterodimerizes with the retinoid $\mathrm{X}$ receptor (RXR), forming CAR/RXR or PXR/RXR complexs (Timsit and Negishi, 2007). A previous report shows that the CAR/PXR complex binds to the Phenobarbital-Responsive Enhancer Module (PBREM) and the distal CAR-responsive element (CAR-RE) (Honkakoski et al., 1998; Wang et al., 2003a). The CAR/RXR complex binding sites has been identified in the CYP2B6 promoter (Honkakoski et al., 1998; Wang et al., 2003a). The Xenobiotic-responsive enhancer module (XREM) has also been identified as the binding site for the PXR/RXR complex, in the CYP3A5 promoter (Goodwin et al., 1999). These binding sites have not been identified in CYP2A5 promoter, however the importance of CAR and PXR in the inducible and basal expression of Cyp2a5 has been demonstrated, suggesting that the binding sites exist in CYP2A5 promoter (Cai et al., 2002; Maglich et al., 2002; Rosenfeld et al., 2003; Foretz et al., 2005).

Nrf2 is a basic-leucine zipper protein that regulates the expression of numerous cytoprotective genes in response to oxidative stress and xenobiotic challenges. Specifically, the target genes are involved in the glutathione synthesis, ROS clearance, xenobiotic metabolism, and drug transport (Okawa et al., 2006; Yates et al., 2009). Under physiological conditions, Nrf2 is bound to its repressor Kelch-like ECH associating 
protein 1 (Keap1) in the cytosol, and is consistently degraded via ubiquitin-proteasome pathway in a Keap1-dependent manner (Itoh et al., 1999; Sekhar et al., 2002; McMahon et al., 2003; Cullinan et al., 2004; Kobayashi et al., 2004). Upon oxidative or electrophilic challenge, the Keap1 protein undergoes a conformational change that leads to disruption of the Keap1-Nrf2 binding (Kobayashi and Yamamoto, 2006). Nrf2 is released from the Keap1-Nrf2 complex and then translocates to the nucleus, then heterodimerizes with small musculo-aponeurotic fibrosarcoma proteins (Mafs) (Itoh et al., 1997). The resulting heterodimer has been shown to bind Maf recognition elements, the antioxidant response element, or the stress response element of various genes (Rushmore et al., 1991; Kataoka et al., 1994; Choi and Alam, 1996). The binding site for the Nrf2-Maf heterodimer in the Cyp2a5 promoter was first identified by Abu-Bakar et al. (2007) at positions -2467 to 2269 (Abu-bakar et al., 2007).

As noted above, the transcriptional regulation of Cyp $2 a 5$ does not involve a single pathway, rather involves numerous signaling pathways and transcriptional factors depending on the physiological states of the subject. However, the majority of the factors involved in Cyp2a5 transcriptional activation appear to play significant role in protection against oxidative stress.

\section{Post-transcriptional regulation of Cyp2a5}

Although it appears that CYP2A5 regulation is most commonly transcriptional, previous studies show that $C y p 2 a 5$ can be also regulated post-transcriptionally. The posttranscriptional regulation of Cyp2a5 identified to date, include mRNA stabilization and protein stabilization to increase expression and activity. The evidence of Cyp2a5 mRNA 
stabilization was first reported by Aida and Negishi (Aida and Negishi, 1991;

Hahnemann et al., 1992). Heterogeneous nuclear ribonucleoprotein A1 (hnRNPA1), a multifunctional protein involved in transcriptional regulation and cell growth, has been identified as the RNA-binding protein responsible for the Cyp2a 5 mRNA stabilization (Tilloy-ellul et al., 1999; Raffalli-Mathieu et al., 2002). These studies have shown that hnRNA1 functions as an mRNA stabilizing trans-acting factor on the 3' UTR, and also acts as a transcriptional activator by interacting with the proximal promoter (Tilloy-ellul et al., 1999; Raffalli-Mathieu et al., 2002; Glisovic et al., 2003). CYP2A5 protein stabilization has been also reported. The evidence for CYP2A5 protein stabilization was first reported by Juvonen et al. (1988) that coumarin, the substrate for CYP2A5 with high affinity, effectively protected CYP2A5 protein from degradation and increased its catalytic activity (Juvonen et al., 1988). Furthermore, very recently, Abu-Bakar et al. (2011) in their study of the role of CYP2A5 in BR metabolism, showed that BR stabilizes CYP2A5 via its substrate function (Abu-Bakar et al., 2011). 


\section{RATIONALE}

Bilirubin (BR) is the end product of heme catabolism with cytoprotective potential at physiological levels and cytotoxic potential at supraphysiological levels (Roy-Chowdhury et al., 2007). The majority of BR is metabolized by UGT1A1 via glucuronidation but previous studies have suggested that BR is also metabolized by CYP2A5 as an alternative pathway (Bosma et al., 1994; Abu-Bakar et al., 2011). AbuBakar et al (2011) recently showed that CYP2A5 is an inducible oxidase that metabolizes BR into biliverdin as its major product, which can potentially prevent accumulation of BR in the cell (Abu-Bakar et al., 2011). However, the regulatory mechanism of CYP2A5 in BR metabolism still remains unclear and the role of CYP2A5 in vivo further remains to be determined.

Recently, Lämsä et al. (2012) showed that heme, the parent compound of BR, regulates Cyp2a5 expression via Nrf2 activation (Lämsä et al., 2012). Nrf2 is one of the transcription factors identified for Cyp2a5, and is involved in regulation of expression of numerous cytoprotective genes in response to oxidative stress and xenobiotic challenges (Itoh et al., 1999; Kobayashi et al., 2004). The cytotoxic effects of BR involve various cell signaling pathways, but it has been suggested that the common mechanism of BRinduced apoptosis or necrosis is in part through production of ROS and RNS (Brites and Brito, 2012). Hence, these findings lead to hypothesis that the regulation of CYP2A5 by BR is mediated by Nrf2 activation and that CYP2A5 prevents the toxicity of BR by direct clearance of BR. 
Objective 1. Determine the effect of BR on CYP2A5 gene expression and the associated regulatory mechanisms.

Approach: Mouse hepatocytes in primary culture were treated with BR and CYP2A5 expression analyzed by real-time RT PCR and western blot. Luciferase reporter assays were used to identify the response elements and transcription factors recruited by BR.

Objective 2. Investigate the cytoprotective role of CYP2A5 in BR toxicity.

Approach: The effect of transient CYP2A5 overexpression on BR-induced apoptosis was assessed in Hepa 1-6 cells transfected with a V5-His-CYP2A5 expression plasmid or the empty vector pcDNA3.1.

Objective 3. Determine if the cytoprotective effect of CYP2A5 on BR-induced cytotoxicity is due to increased bilirubin metabolism.

Approach: BR degradation was assessed in vitro using microsomes from Hepa 1-6 cells transiently overexpressing V5-His-CYP2A5 expression plasmid or the empty vector pcDNA3.1. 


\section{MATERIALS AND METHODS}

\section{PART 1. Animal model and cell culture}

Mice

Male C57BL/6 mice were purchased from Charles River Canada (St. Constant, QC). All the mice were given food and water ad libitum, and were housed at $23.8^{\circ} \mathrm{C}$ with a $12 \mathrm{~h}$ photoperiod. All mouse perfusions were conducted in accordance with the guidelines of Canadian Council on Animal Care and the Animal Care Committee of the University of Guelph.

\section{Mouse liver perfusion}

Mice were anesthetized by an intraperitoneal injection of $0.1 \mathrm{~mL}$ pentobarbital (54.7 mg/mL, Somnotol, MTC Pharmaceuticals). Once sufficiently anesthetized (3-8 minutes), mice were secured in dorsal recumbency. The abdominal and thoracic areas of the mice were wiped with $70 \%$ ethanol. A medial incision was made from the pubis to the sternum using a blunt ended mayo scissors. The intestines were reflected dorsally to the left, and the hepatic portal vein was exposed. The rib cage was then removed and the inferior vena cava was located. A single loose ligature (3-0 silk) was placed around the inferior vena cava, as close to the right atrium as possible.

A 23-gauge catheter was made from polyethylene tubing, beveled at one end and attached to Tygon tubing (Fisher Scientific, Ottawa, ON) that ran through a peristaltic pump from the solutions in a $40^{\circ} \mathrm{C}$ water bath. The blanching solution (Appendix I),

consisting of $1 \mathrm{X}$ Hanks' balanced salt solution (HBSS, without $\mathrm{Ca}^{2+}, \mathrm{Mg}^{2+}, \mathrm{HCO}_{3}{ }^{-}$and 
phenol red; Invitrogen, Burlington, ON), 1 mM EGTA (Sigma-Aldrich, Oakville, ON), and $10 \mathrm{mM}$ HEPES (Sigma-Aldrich, Oakville, ON), was pre-run at a flow rate of 2.0 $\mathrm{mL} / \mathrm{min}$ to exclude air bubbles from the tubing. The inferior vena cava was catheterized via the right atrium, by grasping the left ventricle with small rat tooth forceps and making a small incision into the atrium with iris scissors. The suture was then placed around the inferior vena cava to secure the catheter. The hepatic portal vein was cut once the catheter was in place to allow the solutions to exit after perfusing through liver. The blanching solution was pumped retrograde to blood flow through the liver for 2.5 minutes.

Once the liver was successfully perfused with the blanching solution, as indicated by clearance of blood in liver, the perfusate was changed to $50 \mathrm{~mL}$ of collagenase medium (Appendix I), consisting of $100 \mathrm{U} / \mathrm{mL}$ mouse collagenase type I (Sigma-Aldrich, Oakville, ON), 10 mM HEPES (Sigma-Aldrich, Oakville, ON), and $1.325 \mu \mathrm{L} / \mathrm{mL} 7.5 \%$ bovine serum albumin (Sigma-Aldrich, Oakville, ON) in Williams' Medium E, pH 7.4 (Sigma-Aldrich, Oakville, ON). The collagenase perfusion medium was run at a flow rate of $4.0 \mathrm{~mL} / \mathrm{min}$ for approximately $8-10$ minutes, which allowed hepatocytes to be fully dissociated.

\section{Preparation of primary cultures of mouse hepatocytes}

The liver was removed from the mouse, the gallbladder was excised, and the liver was placed into a sterile $100 \mathrm{~mm}$ Petri dish (Corning, NY). The liver was rinsed with cold attachment medium (Appendix I), which contained 10 mM HEPES pH 7.4 (SigmaAldrich, Oakville, ON), ITS (Roche Diagnostics, Laval, QC; $5 \mu \mathrm{g} / \mathrm{mL}$ insulin, $5 \mu \mathrm{g} / \mathrm{mL}$ transferrin, and $5 \mathrm{ng} / \mathrm{mL}$ sodium selenite), $7.5 \mu \mathrm{g} / \mathrm{mL}$ geneticin (Invitrogen, Burlington, 
ON), 10\% fetal bovine serum (FBS; Sigma-Aldrich, Oakville, ON), $50 \mathrm{nM}$ dexamethasone (Sigma-Aldrich, Oakville, ON) in Williams' Medium E, pH 7.4 (SigmaAldrich, Oakville, ON). The liver capsule was then gently scored with scissors, and the cells were pipetted through sterile gauze into a $50 \mathrm{~mL}$ conical tube (Corning, NY). The cell suspension was centrifuged at $50 \mathrm{~g}$ for $2 \mathrm{~min}$. The pellet of hepatocytes was resuspended in $25 \mathrm{~mL}$ of fresh attachment media.

Isolated mouse primary hepatocytes were plated in 6-well plates (Corning, NY) at a density of $1.0 \times 10^{6}$ cells/well or 24-well plates (Corning, NY) at a density of $0.25 \times 10^{5}$ cells/well in attachment media. After 5 hours of incubation, the attachment media was removed and replaced with fresh serum-free media (Appendix I), which contained 10 mM HEPES pH 7.4 (Sigma-Aldrich, Oakville, ON), ITS (Roche Diagnostics, Laval, QC; $5 \mu \mathrm{g} / \mathrm{mL}$ insulin, $5 \mu \mathrm{g} / \mathrm{mL}$ transferrin, and $5 \mathrm{ng} / \mathrm{mL}$ sodium selenite), $10 \mu \mathrm{g} / \mathrm{mL}$ gentamicin (Invitrogen, Burlington, ON) in Williams' Medium E, pH 7.4 (SigmaAldrich, Oakville, ON) and the cells were incubated in a humidified incubator with 5\% $\mathrm{CO}_{2}$ at $37^{\circ} \mathrm{C}$ for 19 hours.

\section{Hepa 1-6 cell line}

The Hepa 1-6 cell line was obtained from ATCC (Manassas, VA). Hepa 1-6 is a mouse hepatoma cell line derived from the BW7756 tumour that arose in a C57/L mouse. The cells were cultured and maintained with Dulbecco's Modified Eagle's medium (DMEM; Sigma-Aldrich, Oakville, ON) supplemented with 1\% (v/v) Penicillin/Streptomycin (Invitrogen, Burlington, ON) and 10\% (v/v) FBS (SigmaAldrich, Oakville, ON) in $75 \mathrm{~cm}^{2}$ canted neck flasks with vented caps (Corning, NY), in 
a humidified incubator $\left(5 \% \mathrm{CO}_{2}, 37^{\circ} \mathrm{C}\right)$. The cells were counted using a hemocytometer and plated at variable cell densities according to the needs of the experiments.

\section{Bilirubin solubilization}

Bilirubin powder was purchased from Sigma-Aldrich (Oakville, ON). Bilirubin was first dissolved using fixed amount in $0.1 \mathrm{~N} \mathrm{NaOH}(10 \%$ of final volume) and followed by addition of an appropriate volume of PBS, $\mathrm{pH}$ 7.4. All experiments involving bilirubin treatment were protected from exposure to light.

\section{PART 2. Regulation of CYP2A5 by BR}

\section{Treatment}

Cells in 6-well plates were treated with bilirubin $(0,1,10,25,50 \mu \mathrm{M})$ or its vehicle (1\% v/v $0.1 \mathrm{~N} \mathrm{NaOH} \mathrm{PBS,} \mathrm{pH} 7.4)$ in serum-free media for 24 hours.

\section{$\underline{\text { RNA isolation and reverse transcription }}$}

After 24-hour of treatment, the media was removed from the culture plate and the cells were washed with PBS. One $\mathrm{mL}$ of TRIzol reagent (Invitrogen, Burlington, ON) was then added directly to the hepatocytes and the TRIzol-cell homogenate was scrapetransferred to $1.5 \mathrm{~mL}$ RNase-free Eppendorf tubes. Samples were incubated in room temperature for 5 minutes and $200 \mu \mathrm{L}$ of chloroform (Fisher Scientific, Ottawa, ON) was added. The samples were vortexed gently for 15 seconds and then incubated for 2 minutes at room temperature (RT). The samples were centrifuged at 12,000 g for 15 minutes at $4^{\circ} \mathrm{C}$ and the resulting supernatant (approximately $500 \mu \mathrm{L}$ ) was transferred to 
new $1.5 \mathrm{~mL}$ Eppendorf tubes. To each tube, an equal volume $(500 \mu \mathrm{L})$ of cold isopropanol (Fisher Scientific, Ottawa, ON) was added to precipitate RNA and mixed by inverting several times. The samples were then incubated at RT for 10 minutes and centrifuged at $12,000 \mathrm{~g}$ for 15 minutes at $4^{\circ} \mathrm{C}$. The RNA pellets were washed with $1 \mathrm{~mL}$ $75 \%$ ethanol. The samples were centrifuged at $12,000 \mathrm{~g}$ for another 10 minutes and the remaining ethanol was removed. The RNA pellets were then air dried at RT until the pellets turned from opaque to clear, and the pellets were finally dissolved in $12 \mu \mathrm{L}$ of nuclease-free water, and incubated for 10 minutes at $55^{\circ} \mathrm{C}$. The RNA concentration and purity of each sample was determined with a NanoDrop ND-1000 spectrophotometer (Thermoscientific, Ottawa, ON).

Once the mRNA was isolated, $1 \mu \mathrm{g}$ of RNA was treated with 1 unit of DNase (RQ1 RNase-Free DNase; Promega, Madison, WI) at $37^{\circ} \mathrm{C}$ for $30 \mathrm{~min}$, and was reverse transcribed using 200 units of Murine-Moloney Leukemia Virus reverse transcriptase (MMLV RT; Promega, Madison, WI), 20 units of RNase inhibitor (RNasin; Promega, Madison, WI), and $0.1 \mu \mathrm{g}$ of (Invitrogen, Burlington, $\mathrm{ON}$ ) primers for 1 hour at $37^{\circ} \mathrm{C}$.

\section{Real-time RT-PCR}

CYP2A5 mRNA analysis was conducted by relative real-time reverse transcription polymerase chain reaction (RT-PCR) using a Roche Molecular Biochemicals Lightcycler (Indianapolis, IN) and the FastStart SYBR Green Master Mix (Roche Diagnostics, Mississauga, ON). PCR was performed in a $10 \mathrm{uL}$ volume containing a $2 \mathrm{uL}$ sample of cDNA, $1 \mu \mathrm{L}$ of SYBR Green Master Mix, $2 \mathrm{mM} \mathrm{MgCl} 2$, and $5 \mu \mathrm{M}$ of each primer. The PCR parameters were as follows: denaturation $\left(95^{\circ} \mathrm{C}\right.$ for 10 
min), 45 cycles of PCR $\left(95^{\circ} \mathrm{C}, 15 \mathrm{sec} ; 70,5 \mathrm{sec} ; 72^{\circ} \mathrm{C}, 15 \mathrm{sec}\right)$. The threshold cycle at which the fluorescent signal reached an arbitrarily set threshold near the middle of the log-linear phase of amplification for each reaction was calculated and relative quantities of mRNA for the Cyp2a5 gene were analyzed. The mRNA levels were normalized against mRNA levels of the housekeeping gene GAPDH. The gene specific primers for Cyp2a5 and GAPDH were as follows:

Cyp2a5 (1,746 bp)

Forward 5'-GGACAAAGAGTTCCTGTCACTGCTTC-3' (606-631)

Reverse 5'-GTGTTCCACTTTCTTGGTTATGAAGTCC-3' (759- 786)

GAPDH $(1,002 \mathrm{bp})$

Forward 5'-ACAGTCCATGCCATCACTGCC-3' (581-601)

Reverse 5'-GCCTGCTTCACCACCTTCTTG-3' (826-846)

\section{Western Blotting}

After 24 hours of treatment, the medium was removed from the culture plate and the cells were washed with PBS. One hundred $\mu \mathrm{L}$ of cell lysis buffer (Appendix I) was directly added to hepatocytes and incubated for 5 minutes at RT. The cell homogenate was then scraped, transferred to $1.5 \mathrm{~mL}$ Eppendorf tubes and centrifuged at $10,000 \mathrm{~g}$ for 10 minutes at $4{ }^{\circ} \mathrm{C}$. The resulting supernatant, total protein concentration was measured by the Bradford method using the Bio-Rad Protein Assay Reagent (Bio-Rad Laboratories, Mississauga, $\mathrm{ON})$. 
Hepatic CYP2A5 protein expression was analyzed by western blot analysis as described previously (Gilmore and Kirby, 2004). Briefly, sample proteins (25 $\mu$ g protein per lane) were separated by SDS-PAGE on a 10\% gel and transferred to Amersham Hybond ECL membrane (GE Healthcare, Oakville, ON). Membranes were blocked in blocking buffer $(5 \% \mathrm{v} / \mathrm{v}$ powdered skim milk in Tris-buffered saline with $0.5 \%$ Tween20, TBS) for 1 hour at RT. Membranes were then incubated with chicken anti-mouse Cyp2a5 (1:10,000; 2 h; Dr.Juvonen, Kuopio, Finland) or mouse anti- $\beta$-actin (1:5000; 30 min; Sigma-Aldrich, Oakville, ON) polyclonal antibodies in blocking buffer at RT, followed by HRP-conjugated goat anti-chicken $\operatorname{IgG}(1: 10,000 ; 1 \mathrm{~h}$; Sigma-Aldrich, Oakville, ON) or HRP-conjugated goat anti-mouse IgG (1:2000; 30 min; Sigma-Aldrich, Oakville, ON) in blocking buffer at RT. Protein bands were detected with ECL plus (Amersham Biosciences, Baie d'Urfe, QC) and the molecular mass was confirmed with precision plus molecular weight markers (Bio-Rad Laboratories, Mississauga, ON). The bands were scanned with a Typhoon 9410 scanner (GE Health Sciences, Piscataway, NJ) and the band intensity was quantified with ImageQuant TL (GE Health Sciences, Piscataway, NJ). The band intensity was normalized to $\beta$-actin and shown as fold-change.

\section{$\underline{\text { Luciferase reporter constructs }}$}

A number of various expression vectors and reporter constructs were used in transient transfection assay. A reporter construct consisting of the luciferase gene under the control of a $3033 \mathrm{bp}$ fragment of the Cyp2a5 promoter region (Cyp2a5 5'-3033/+10) was provided by Dr. Jukka Hakkola (University of Oulu, Finland). Various deletion constructs of the Cyp $2 a 5$ promoter $(-2603 /+10,-2263 /+10,-746 /+10,-432 /+10)$ were 
provided by Andrea Leclair (Leclair, 2004). The Cyp2a 5 5'-3033/+10 promoter construct with site-directed mutation of the Nrf2 response element (Cyp2a5 5'-3033/+10- $\Delta \mathrm{Nrf2}$ ) was provided by Kathleen Nichols (Nichols, 2009).

The promoter constructs were cotransfected either with the empty expression plasmid pcDNA3.1 or with the mouse Nrf2 expression plasmid (pcDNA3.1-mNrf2). The Nrf2 expression plasmid was provided by Dr. Ah-Ng (Tony) Kong (University of New Jersey, USA).

Transfection of primary mouse hepatocytes

Cyp2a5 5'-3033/+10 promoter construct, 5'-truncated fragments, and Nrf2 response element mutant were used in transient transfection assays. The promoter constructs were co-transfected either with pcDNA3.1 or with the mouse pcDNA3.1$\mathrm{mNrf2}$. The primary mouse hepatocytes cultured in $24-$ well plate were transiently transfected using Lipofectamine 2000 (Invitrogen, Burlington, ON) according to the manufacturer's protocol. Cells in each well were transfected with $0.5 \mu \mathrm{g}$ of Cyp2a5 5' reporter construct, $0.3 \mu \mathrm{g}$ of pcDNA3.1 or pcDNA3.1-mNrf2, and $0.2 \mu \mathrm{g}$ of Renilla (pRL3-TK). The transfected cells were cultured for 24 hours and treated with $50 \mu \mathrm{M} \mathrm{BR}$ or its vehicle for another 24 hours.

\section{Dual Luciferase Activity Assay}

The luciferase activities were assessed on a FLUOstar OPTIMA using the DualLuciferase Reporter Assay System (Promega, Madison, WI) according to the manufacturer's recoomendations. Briefly, the media from the cultured cells were 
removed and the cells were washed with PBS. The cells were passively lysed with Passive Lysis Buffer for 15 min on shaker. The cell lysate were collected to Eppendorf microcentrifuge tubes and $20 \mu \mathrm{L}$ of each sample was transferred to 96-well plate (flat bottom, white polystyrene). The firefly luciferase activity was first measured after $100 \mu \mathrm{L}$ of Luciferase Assay Substrate injection and then Renilla luciferase activity was subsequently measured after the injection of $100 \mu \mathrm{L}$ Stop \& Glo Reagent. The resulting values are normalized against luciferase activity in cells transfected with the empty vector, pRL3-TK.

\section{PART 3. Cytoprotective role of CYP2A5 in BR toxicity}

Transfection of Hepa 1-6 with CYP2A5 overexpression vectors

CYP2A5 overexpression in Hepa 1-6 was achieved via transfection with pcDNA3.1/V5-His-TOPO into which Cyp2a5 cDNA had been cloned (pCYP2A5-V5), a kind gift from Dr. Masahiko Negishi (NIEHS, USA). The cells were also co-transfected with an expression vector, pcDNA3.1/V5-His-TOPO, containing cDNA for porcine cytochrome P450 oxidoreductase (pPOR-V5) provided by Dr. Jim Squires (University of Guelph, ON) to supply electrons for the overexpressed CYP2A5 protein. Hepa 1-6 cells were cultured in 6-well plates (Corning, NY) at a density of $0.4 \times 10^{6}$ cells/well in DMEM supplemented with 1\% (v/v) Penicillin/Streptomycin (Invitrogen, Burlington, $\mathrm{ON})$ and 10\% (v/v) FBS (Sigma-Aldrich, Oakville, ON). The cells were incubated in a $5 \% \mathrm{CO}_{2}$, humidified incubator at $37^{\circ} \mathrm{C}$ for 24 hours to achieve $70-80 \%$ confluency. At confluency, the cells were transiently transfected using Lipofectamine 2000 (Invitrogen, Burlington, $\mathrm{ON}$ ) according to the manufacturer's protocol. Cells in each well were 
transfected with $2.0 \mu \mathrm{g}$ of pcDNA3.1 or CYP2A5-V5 plasmid. The cells were also cotransfected with $0.4 \mu \mathrm{g}$ pcDNA3.1 or POR. The transfected cells were cultured for 24 hours and further treated with $\mathrm{BR}(0,1,10,25,50 \mu \mathrm{M})$ or the vehicle $(1 \% \mathrm{v} / \mathrm{v} 0.1 \mathrm{NaOH}$ PBS, pH 7.4 in serum-free media for 24 hours.

\section{CYP2A5 activity assay: 7-ethoxycoumarin deethylation assay}

To confirm the activity of overexpressing CYP2A5 protein, the metabolism of coumarin was measured in CYP2A5 and POR overexpressing Hepa 1-6 cells. At 24 hours after transfection, 7-ethoxycoumarin (Sigma-Aldrich, Oakville, ON) was added in fresh media to the 6-well plate. After incubation for 2 hours, the media was collected and the cells were harvested. For media samples, trichloroacetic acid $(20 \% \mathrm{v} / \mathrm{v})$ was added to precipitate out protein and was centrifuged at $15,000 \mathrm{~g}$ for 15 minutes at $4^{\circ} \mathrm{C}$. The resulting supernatant was injected to a HPLC on a Luna $5 \mu 250 \mathrm{~mm}$ x $4.6 \mathrm{~mm}$ reverse phase C-18 column (Phenomenex, Torrance, CA) using a mobile phase of 5\% acetonitrile, $95 \%$ water, $0.2 \%$ acetic acid at a flow rate of $1 \mathrm{~mL} / \mathrm{min}$. The equipment consisted of a Spectra Physics HPLC system (Spectra-Physics, San Jose, CA) equipped with a Spectra $100 \mathrm{UV}-$ Vis Detector set at $320 \mathrm{~nm}$. 7-hydroxycoumarin was used as internal control. The retention time for coumarin, 7-hydroxycoumarin, and 7ethoxycoumarin were $11 \mathrm{~min}, 7.7 \mathrm{~min}$, and $16 \mathrm{~min}$ respectively. The concentration of metabolites were first normalized to the internal control, and then normalized to total protein concentration from the cells harvested previously. 


\section{Western Blotting}

To determine BR-induced apoptosis in Hepa 1-6 cells, caspase-3 cleavage was demonstrated using western blot analysis. Briefly, sample proteins (40 $\mu$ g protein per lane) were separated by SDS-PAGE on a 10\% gel and transferred to Amersham Hybond ECL membrane (GE Healthcare, Oakville, ON). Membranes were then incubated with rabbit anti-mouse caspase-3 (1:1000; overnight; Cell signaling) or mouse anti- $\beta$-actin (1:5000; 30 min; Sigma-Aldrich, Oakville, ON) polyclonal antibodies in blocking buffer at RT, followed by HRP-conjugated goat anti-rabbit IgG (1:2000; $1 \mathrm{~h}$; Sigma-Aldrich, Oakville, ON) or HRP-conjugated goat anti-mouse IgG (1:2000; 30 min; Sigma-Aldrich, Oakville, ON) in blocking buffer at RT. Also to confirm the protein expression of transfected pcDNA3.1/V5-His-TOPO expression plasmids, the membranes were also incubated with mouse anti-V5 (1:5000; Invitrogen, Burlington, ON) for 1 hour at RT, followed by HRP-conjugated goat anti-mouse IgG (1:2000; Sigma-Aldrich, Oakville, ON) for 1 hour at RT.

Protein bands were detected with ECL plus (Amersham Biosciences, Baie d'Urfé, QC) and the molecular mass was confirmed with precision plus molecular weight markers (Bio-Rad Laboratories, Mississauga, ON). The bands were scanned with a Typhoon 9410 scanner (GE Health Sciences, Piscataway, NJ) and the band intensity was quantified with ImageQuant TL (GE Health Sciences, Piscataway, NJ). The band intensity was normalized to $\beta$-actin and shown as fold-change. 


\section{PART 4. Bilirubin disappearance activity}

Transfection of Hepa 1-6 with CYP2A5 overexpression vectors

Hepa 1-6 cells were cultured in $100 \mathrm{~mm}$ dish (11 dish per each plasmid; Corning, NY) at a density of $3.0 \times 10^{6}$ cells/well in DMEM supplemented with $1 \%(\mathrm{v} / \mathrm{v})$ Penicillin/Streptomycin (Invitrogen, Burlington, ON) and 10\% (v/v) FBS (SigmaAldrich, Burlington, $\mathrm{ON}$ ). The cells were incubated in a $5 \% \mathrm{CO}_{2}$, humidified incubator at $37^{\circ} \mathrm{C}$ for 24 hours to achieve $70-80 \%$ confluency. Once confluency was reached, cells were transiently transfected with $13.0 \mu \mathrm{g}$ pcDNA3.1 or pCYP2A5-V5 plasmids using Lipofectamine 2000 (Invitrogen, Burlington, ON) according to the manufacturer's protocol. Cells were also cotransfected with $1.2 \mu \mathrm{g}$ pcDNA3.1 or pPOR-V5. The transfected cells were cultured for 24 hours.

\section{Microsomal protein extraction}

After 24 hours transfection of cells, the media was removed from the culture plate and the cells were washed twice with ice-cold PBS. Cells were scraped and pulled into one sterile $15 \mathrm{~mL}$ conical tube (Fisher Scientific, Ottawa, ON). The cell suspension was centrifuged at $200 \mathrm{~g}$ for 2 minutes and supernatant was aspirated. The weight of pellet was then measured and the pellet was resuspended into $3 \mathrm{x}(\mathrm{w} / \mathrm{v})$ homogenization buffer (Appendix I; 20\% sucrose, $100 \mathrm{mM}$ Tris- $\mathrm{HCl}, \mathrm{pH} \mathrm{7.4,} 4^{\circ} \mathrm{C}$ ). The suspended cells were transferred into $5 \mathrm{~mL}$ glass homogenizer coated with teflon, and homogenized with 50 strokes. The homogenate was centrifuged at $10,000 \mathrm{~g}$ for 30 minutes at $4{ }^{\circ} \mathrm{C}$ and the supernatant was transferred to a $3.0 \mathrm{~mL}$ polycarbonate tube, and recentrifuged at 105,000 $\mathrm{g}$ for 1 hour at $4^{\circ} \mathrm{C}$. The supernatant was aspirated and the pellet was resuspended in $1 \mathrm{x}$ 
(v/v) microsomal storage buffer (Appendix I; 20\% glycerol, 100 mM Tris-HCl, $\mathrm{pH} 7.4$, $\left.4^{\circ} \mathrm{C}\right)$. Protein concentration was measured by the Bradford method using the Bio-Rad Protein Assay Reagent (Bio-Rad Laboratories, Mississauga, ON). Freshly made microsomal protein was used within 2 hours for the BR disappearance assay.

\section{Bilirubin disappearance assay}

The bilirubin disappearance assay was determined as previously described (AbuBakar et al., 2005) with a slight modification. Briefly, incubation buffer ( $0.1 \mathrm{M}$ Tris- $\mathrm{HCl}$ $\mathrm{pH}$ 8.2, $26 \mathrm{mM} \mathrm{KCl}, 2 \mathrm{mM}$ EDTA) was mixed with CYP2A5-overexpressing microsomes $(1 \mathrm{mg} / \mathrm{mL}$ final protein concentration) in a total volume of $200 \mu \mathrm{L}$ was placed in $96-$ well plate (Corning, NY) in triplicate. After 5 min pre-incubation, NADPH $(2.0 \mathrm{mM})$ was added to both sample and control wells, and blank absorbance was taken at $450 \mathrm{~nm}$. Immediately, BR in DMSO (10 $\mu \mathrm{M}$ final concentration) was added to the sample plate and absorbance at $450 \mathrm{~nm}$ was recorded for 3 cycles at $10 \mathrm{~min} / \mathrm{cycle}$. The rate of BR disappearance is expressed as pmol BR disappearing $/ \mathrm{hr} / \mathrm{mg}$ protein, using a $\varepsilon=35.127$ $\mathrm{cm}^{-1} \mathrm{mM}^{-1}$, which was obtained experimentally under the conditions of the assay. Additional wells containing the above mixture without NADPH were also run to control for the spontaneous disappearance of BR.

\section{PART 5. Statistical analysis}

All data are shown as mean $\pm \mathrm{SEM}$. One-way repeated measures analysis of variance (ANOVA), followed by Dunnett's post-hoc test was used to determine significance between experimental groups with one independent variable (IV). Two-way 
repeated measures ANOVA, followed by Bonferroni's post-hoc test was used to determine significance between experimental groups with two or more IVs (Prism 5.0, GraphPad Software Inc., La Jola, CA, USA). A probability level of $\mathrm{P}<0.05$ was considered significant. 


\section{RESULTS}

\section{BR induces CYP2A5 $\mathrm{mRNA}$ and protein expression in mouse primary hepatocytes}

To investigate whether BR regulates CYP2A5 at both the transcriptional and translational level, isolated primary hepatocytes from C57BL/6 mice were treated with vehicle $(1 \% \mathrm{v} / \mathrm{v} 0.1 \mathrm{NaOH}$ PBS, $\mathrm{pH} 7.4)$ or $\mathrm{BR}(0,1,10,25,50 \mu \mathrm{M})$ in serum-free media for 24 hours. CYP2A5 mRNA levels were determined by RT-PCR and were normalized with GAPDH mRNA expression. CYP2A5 mRNA levels did not change at low-dose BR $(1,10 \mu \mathrm{M})$ treatment, but was significantly increased (2- and 3-fold induction; $P<$ $0.0001)$ at higher-dose BR $(25,50 \mu \mathrm{M})$ treatment (Figure 1). CYP2A5 protein expression was determined by Western blot analysis using chicken anti-mouse CYP2A5 or anti- $\beta$ actin antibody. Western blotting for CYP2A5 in mouse primary hepatocytes showed similar results with protein levels corresponding to the changes in mRNA transcript levels. CYP2A5 protein expression did not change at low-dose BR $(1,10 \mu \mathrm{M})$ treatment, but was significantly increased (1.7- and 2 -fold induction; $P<0.05$ and $P<0.001)$ at higher-doses of BR $(25,50 \mu \mathrm{M})$ (Figure 2). 


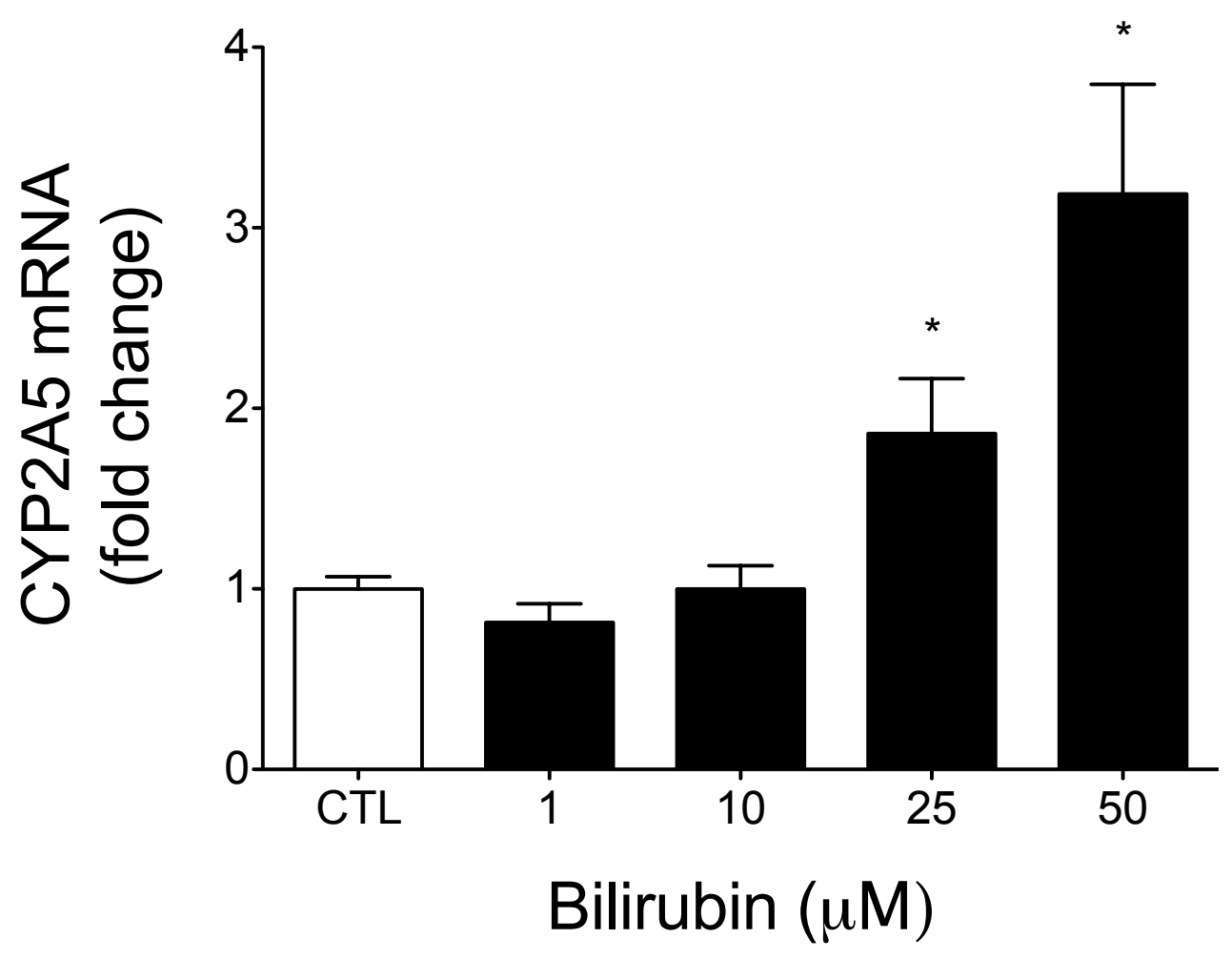

Figure 1. Effect of BR on CYP2A5 mRNA expression. Mouse primary hepatocytes were treated with 1, 10, 25 or $50 \mu \mathrm{M}$ BR for $24 \mathrm{~h}$. CYP2A5 mRNA levels were determined by RT-PCR and normalized to GAPDH mRNA expression. All values represent the mean \pm SEM ( $\mathrm{n}=6$ independent mice) normalized against the control levels. Mean difference is significant from control group at $* P<0.0001$ (one-way repeated measures ANOVA followed by Dunnett's post-test). 
A

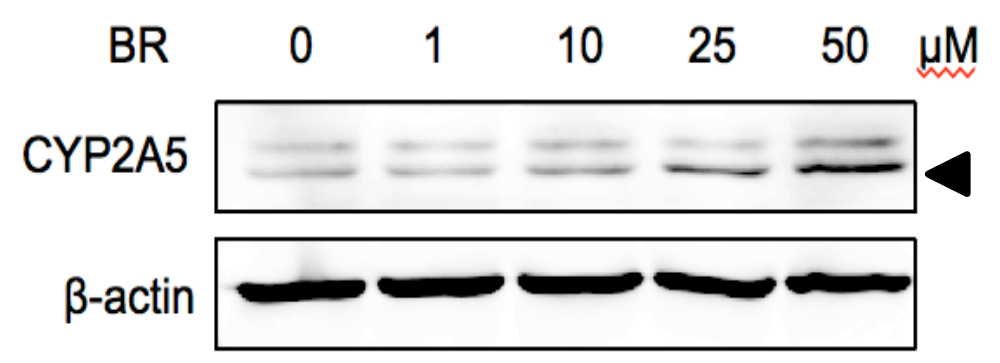

B

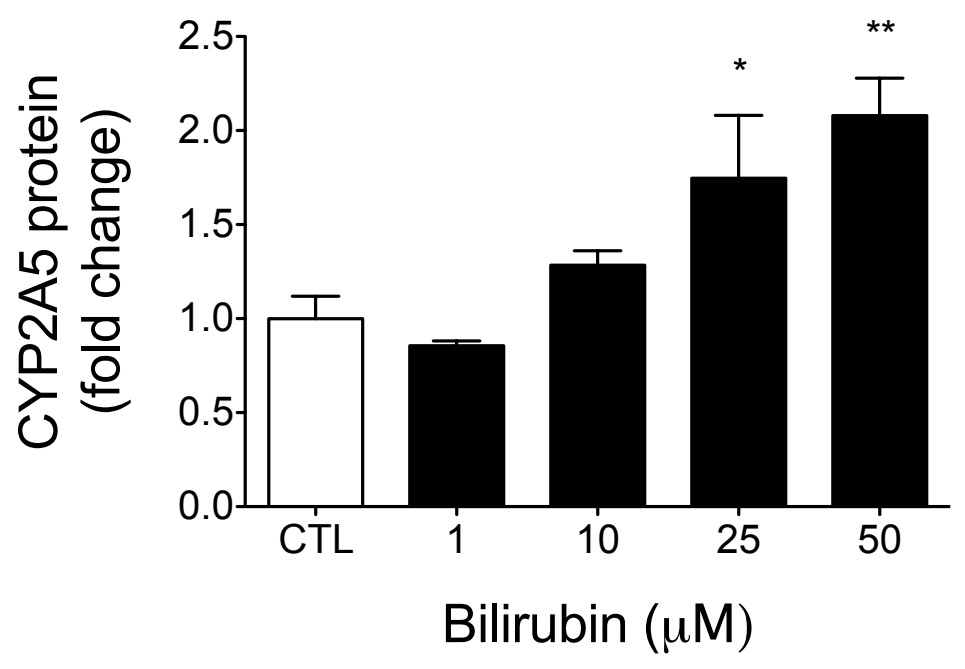

Figure 2. Effect of BR on CYP2A5 protein expression. Mouse primary hepatocytes were treated with 1, 10, 25 or $50 \mu \mathrm{M}$ BR for $24 \mathrm{~h}$. (A) Western blot analysis of total protein ( $25 \mu \mathrm{g}$ total protein/lane) from control and BR-treated mouse primary hepatocytes probed with chicken anti-mouse Cyp2a5 or mouse anti- $\beta$-actin antibody. $\beta$-actin protein levels are shown as control for protein loading. Each blot represents one of replicates of three samples (each blot showed the same pattern of induction). (B) Densitometric quantification of Western blots. All values represent the mean $\pm \operatorname{SEM}(n=3$ independent mice) normalized against the control levels. Mean difference is significant from control group at $* P<0.05$ and ${ }^{* *} P<0.001$ (one-way repeated measures ANOVA followed by Dunnett's post-test). 
BR induction of CYP2A5 mRNA may not be directly regulated in hepatocytes

Since we hypothesized CYP2A5 is regulated by BR at the transcriptional level, to investigate the mechanism of CYP2A5 induction by $\mathrm{BR}$, luciferase reporter assays were performed using a Cyp2a5 reporter construct (Cyp2a5-3033). The Cyp2a5-3033 reporter construct consists of the luciferase gene under the control of a $3033 \mathrm{bp}$ fragment of the Cyp2a5 5' untranslated region (Cyp2a5 5'-3033/+10). The Cyp2a5-3033 and Renilla (pRL3-TK) control vector was transfected into primary mouse hepatocytes for 24 hours. The cells were then treated with vehicle or $50 \mu \mathrm{M}$ BR for another 24 hours, and reporter activity was measured. BR treatment did not alter luciferase activity (Figure 3). 


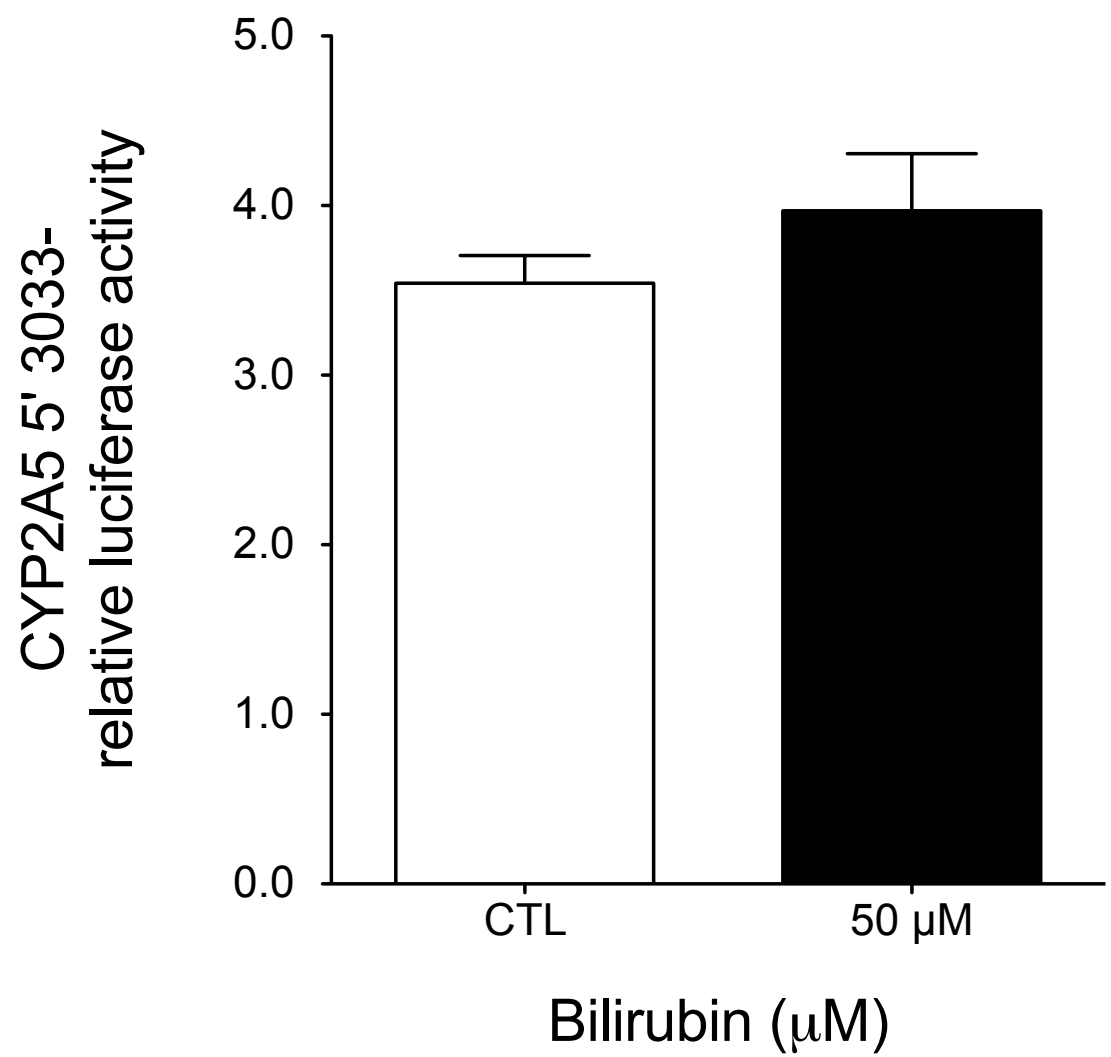

Figure 3. Effect of $50 \mu \mathrm{M}$ BR on Cyp2a5-5'-luciferase activities in C57BL/6 mouse primary hepatocytes. Luciferase activities were measured $24 \mathrm{~h}$ after transfection. The measured activities were normalized against Renilla (pRL-TK) activities. All values represent the mean $\pm \operatorname{SEM}(n=5$ independent mice $)$. 


\section{CYP2A5 induction by BR is mediated by Nrf2}

To investigate if CYP2A5 expression is indirectly regulated by BR in hepatocytes, we introduced mouse Nrf2, the transcription factor for CYP2A5 expression, into our reporter assay system. To confirm the involvement of Nrf2 in the regulation of CYP2A5 expression, the Cyp2a5-3033 was cotrasfected either with pcDNA3.1 or with pcDNA3.1-mNrf2 for 24 hours. Also to investigate if $\mathrm{Nrf} 2$ is involved in regulation of BR-induced CYP2A5 expression, Cyp2a5-3033 was cotransfected either with pcDNA3.1 or with pcDNA3.1-mNrf2 for 24 hours, and treated with vehicle or $50 \mu \mathrm{M}$ BR for another 24 hours. Nrf2 overexpression in the hepatocytes increased the reporter activity in a dosedependent manner, and overexpression of $0.3 \mu \mathrm{g}$ pcDNA3.1-mNrf2 significantly increased the reporter activity approximately by 1.9 -fold $(P<0.05)$ relative to control (Figure 4). Furthermore, BR treatment within the Nrf2 overexpressing group had a profound effect on Cyp2a5 reporter activity. In the Nrf2 overexpressing group, $50 \mu \mathrm{M}$ BR treatment significantly increased the reporter activity by 2 -fold $(P<0.001)$ relative to the vehicle-treated group (Figure 5). 


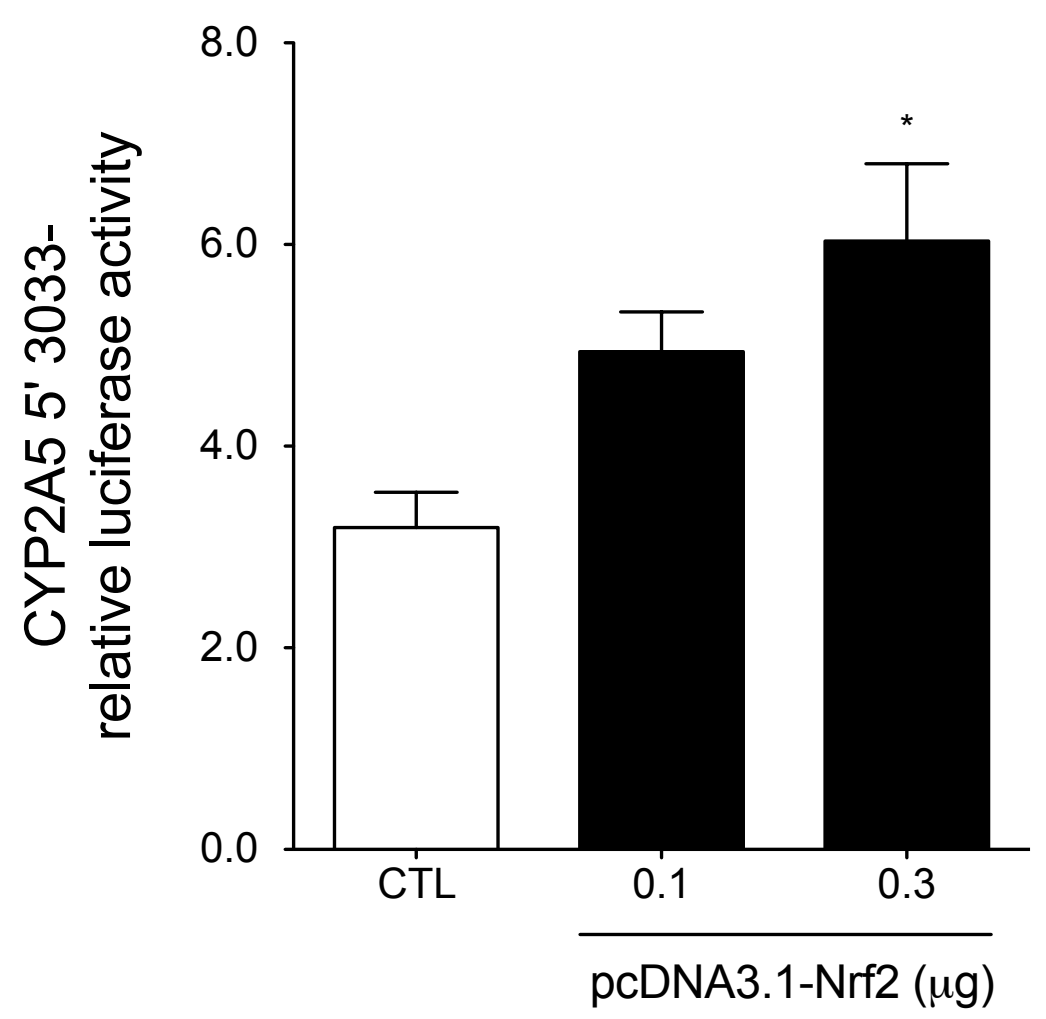

Figure 4. Nrf2 increases CYP2A5 transcription in primary mouse hepatocytes. Primary mouse hepatocytes were transfected with $\mathrm{Nrf2}(0.1$ or $0.3 \mu \mathrm{g})$ and luciferase activities were measured $24 \mathrm{~h}$ after transfection. The measured activities were normalized against Renilla (pRL-TK) activities. All values represent the mean \pm SEM $(n=3$ independent mice). Mean difference is significant from control group at $* P<0.05$ (one-way repeated measures ANOVA followed by Dunnett's post-test). 


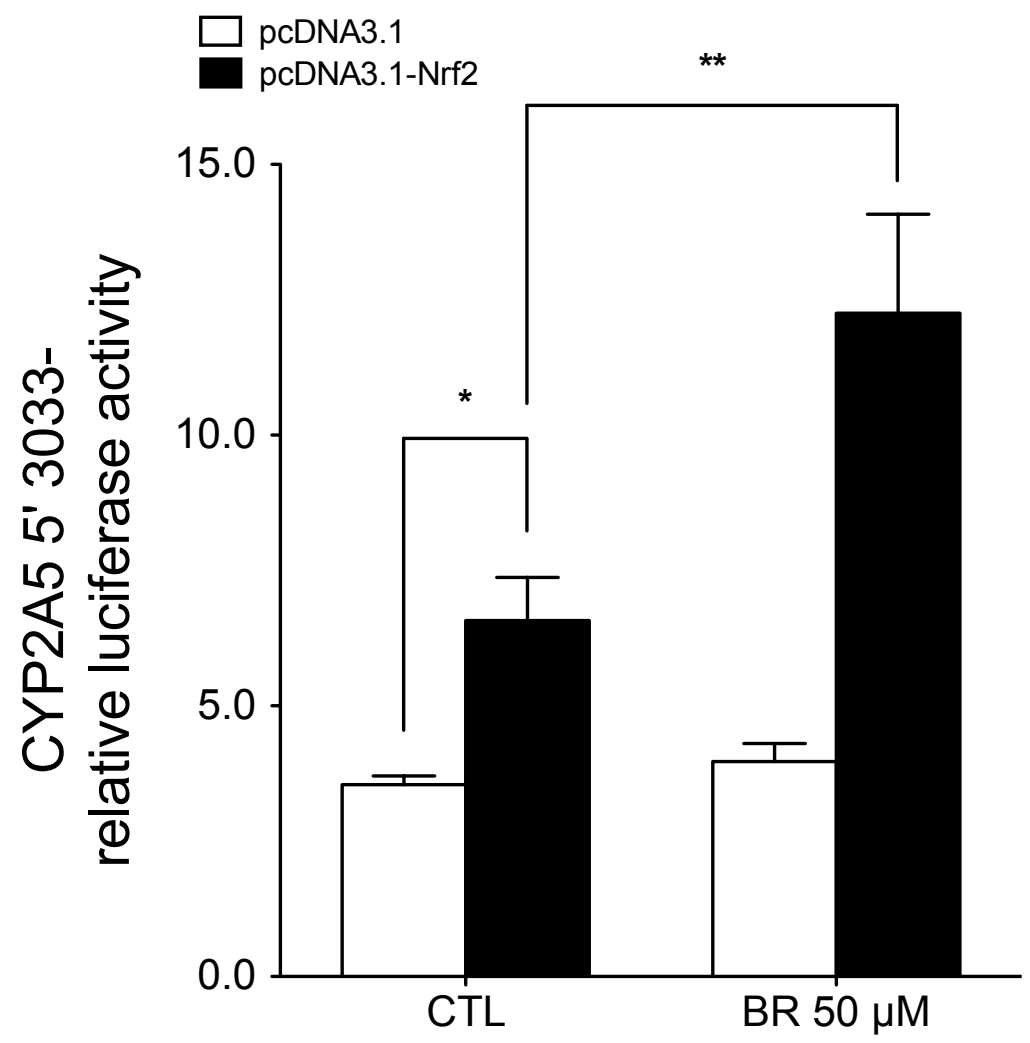

Figure 5. BR increases CYP2A5 transcription in primary mouse hepatocytes in the presence of Nrf2. Primary mouse hepatocytes were transfected with Nrf2 (0.3 $\mu \mathrm{g})$ and treated with BR $(50 \mu \mathrm{M})$ for $24 \mathrm{~h}$. Luciferase activities were normalized against Renilla (pRL-TK) activities. All values represent the mean $\pm \operatorname{SEM}(\mathrm{n}=5$ independent mice). Mean difference is significant from control group at $* P<0.0001$ and $* * P<0.001$ (twoway ANOVA followed by Bonferroni post-test). 
Transcriptional activation of CYP $2 A 5$ by BR involves a StRE in the CYP $2 A 5$ promoter

It was previously shown that increased CYP2A5 transcription was due to Nrf2 binding to StRE at position -2467 to -2269 of the Cyp2a5 5'-flanking region (Abu-bakar et al., 2007). To confirm this finding, luciferase activity was measured in mouse hepatocytes co-transfected with $\mathrm{Nrf2}(0.3 \mu \mathrm{g})$ and various truncation constructs ($2603 /+10,-2263 /+10,-746 /+10$, and $-432 /+10)$ of the Cyp $2 a 5$ promoter. Nrf2 overexpression significantly induced reporter activity in the reporter constructs containing $-3033 /+10$ and $-2603 /+10$ fragments $(P<0.01$ and $P<0.001)$, but had no effect on the constructs of shorter length (Figure 6).

\section{CYP2A5 induction by BR requires $N r f 2$}

In order to further determine if $\mathrm{Nrf2}$ is required for BR-induced CYP2A5 expression, we used the Cyp2a5-3033 with a site-directed mutation of the Nrf2 response element (Cyp2a5- $\Delta \mathrm{Nrf2})$. Mouse hepatocytes were transfected with either the Cyp2a53033 or the Cyp2a5- $\Delta \mathrm{Nrf2}$ reporter constructs followed by cotransfection with either pcDNA3.1 or pcDNA3.1-mNrf2. Nrf2 overexpression induced the reporter activity as shown previously (Figure 7a). The groups of cells cotransfected with pcDNA3.1-mNrf2 were also treated with $50 \mu \mathrm{M} \mathrm{BR}$, and the reporter activity of both Cyp2a5-3033 and Cyp2a5- $\Delta \mathrm{Nrf2}$ constructs was determined. The BR-mediated increase in CYP2A5 reporter activity was abolished in hepatocytes co-transfected with the Cyp2a5- $\Delta \mathrm{Nrf2}$ construct (Figure 7b). 


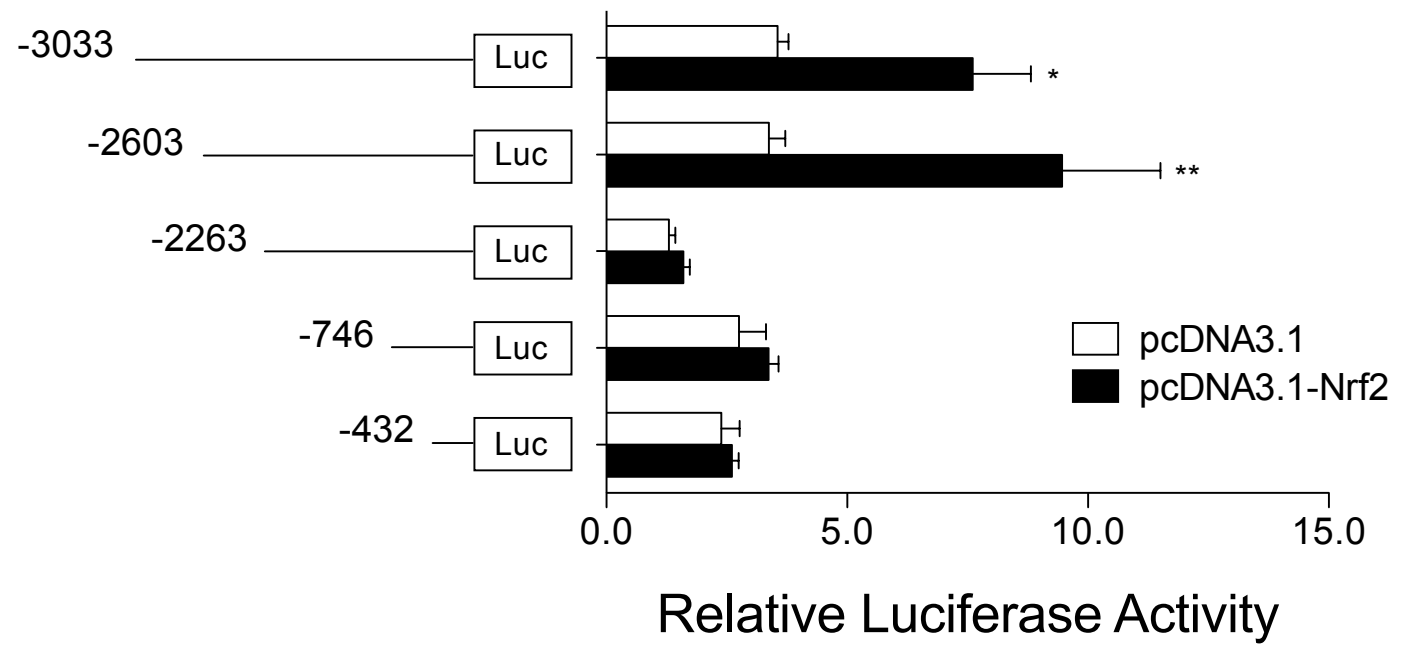

Figure 6. Effect of Nrf2 cotransfection on Cyp2a5-5'-luciferase activities in different reporter constructs transfected in C57BL/6 mouse primary hepatocytes. Luciferase activities were measured $24 \mathrm{~h}$ after transfection. The measured activities were normalized against Renilla (pR-TK) activities. All values represent the mean $\pm \operatorname{SEM}(\mathrm{n}=3$ independent mice). The effect of Nrf2 on each reporter construct is indicated by fold activity relative to control hepatocytes cotransfected with pcDNA3.1. Mean difference is significant from control group at $* P<0.01$ and ${ }^{* *} P<0.001$ (two-way ANOVA followed by Bonferroni post-test). 

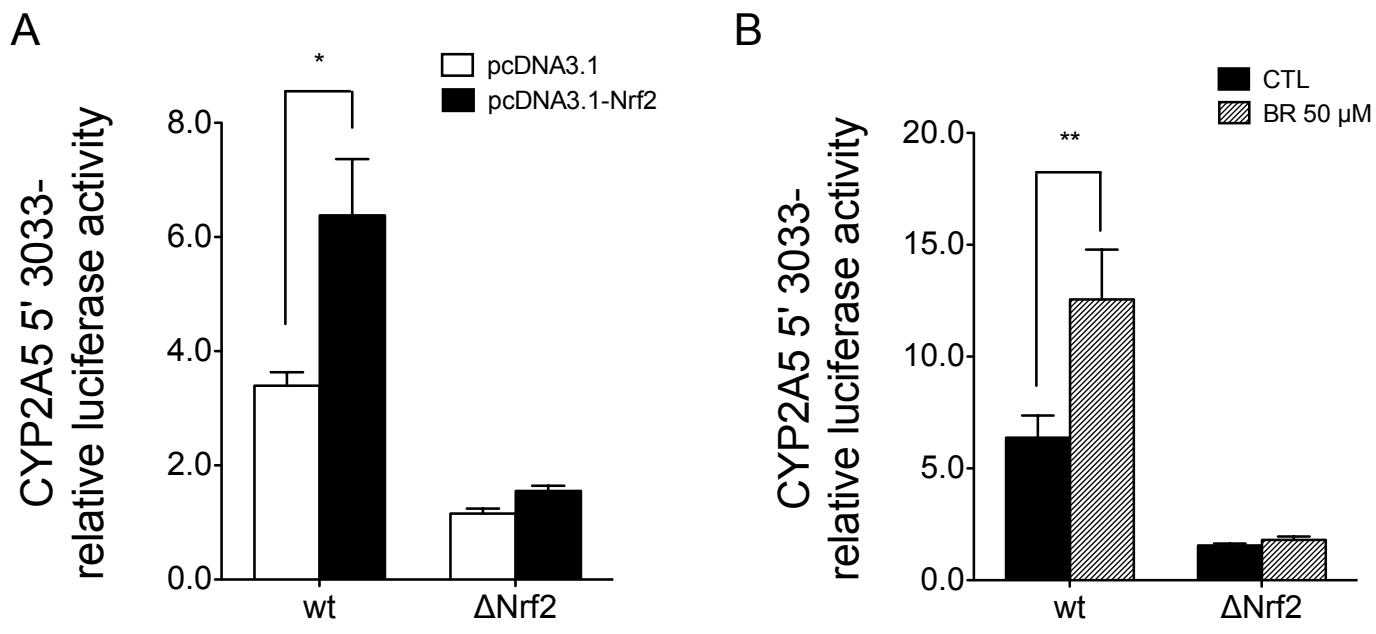

Figure 7. BR-mediated increased CYP2A5 transcription requires the Nrf2 response element in the CYP2A5 promoter. Cyp2a5-5'-luciferase activities were assessed primary mouse hepatocytes $24 \mathrm{~h}$ after (A) Nrf2 cotransfection or (B) Nrf2 cotransfection followed by $50 \mu \mathrm{M}$ BR. The measured activities were normalized against Renilla (pRL-TK) activities. All values represent the mean $\pm \operatorname{SEM}(n=4$ independent mice). Mean difference is significant from the control group at $* P<0.001$ and $* * P<0.01$ (two-way ANOVA followed by Bonferroni post-test). wt, wild-type Cyp2a5-5'-luciferase construct; $\Delta \mathrm{Nrf} 2$, Cyp2a5-5'-luciferase construct with mutated Nrf2 response elements. 
BR activates caspase-3 cleavage in Hepa 1-6 and mouse primary hepatocytes

In order to investigate BR toxicity in mouse hepatocytes, caspase-3 cleavage, a marker of apoptosis, was analyzed after Hepa 1-6 cells and mouse primary hepatocytes were treated with increasing doses of BR $(0,1,10,25,50 \mu \mathrm{M})$. Western blot analysis was performed to detect caspase-3 cleavage following the treatments. Caspase- 3 cleavage was detected with 10,25 , and $50 \mu \mathrm{M}$ BR treatments in the primary hepatocytes, but only with 25 and $50 \mu \mathrm{M}$ BR treatments in Hepa 1-6 (Figure 8). In addition, the greatest degree of caspase-3 cleavage was observed at the highest-dose of BR $(50 \mu \mathrm{M})$ in both cell types (Figure 8). 
A

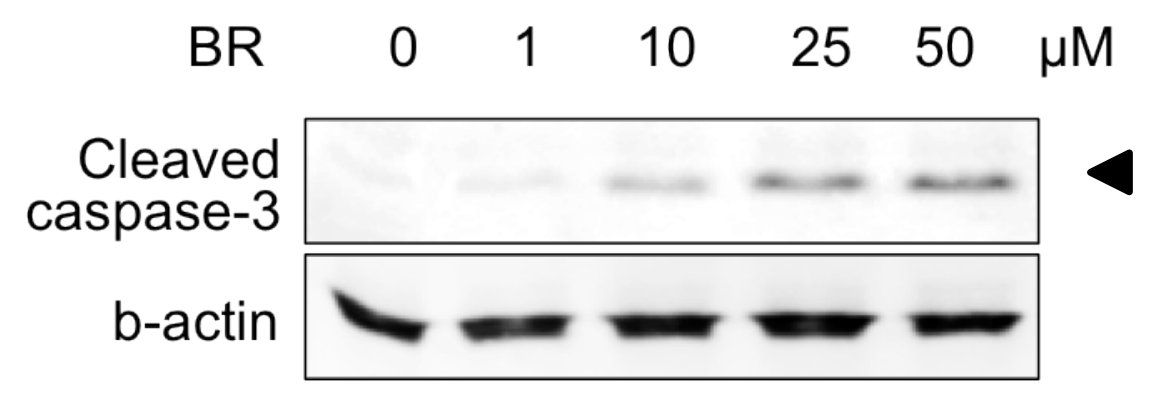

B

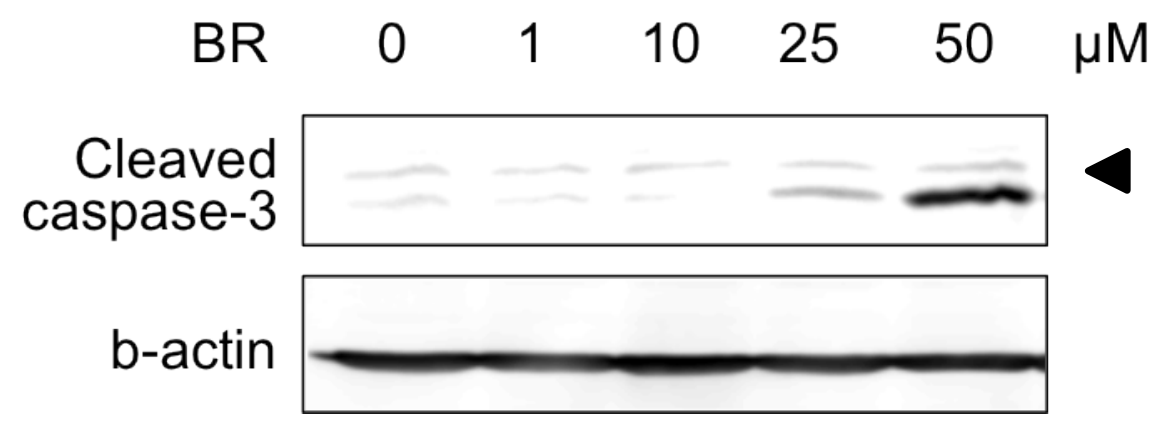

Figure 8. Effect of BR on caspase-3 cleavage in (A) Mouse primary hepatocytes and (B) Hepa 1-6 cells. Both mouse primary hepatocytes and Hepa 1-6 cells were treated with 1, 10,25 or $50 \mu \mathrm{M} \mathrm{BR}$ for $24 \mathrm{~h}$. Western blot analysis of total protein $(40 \mu \mathrm{g}$ total protein/lane) from control and BR-treated cells were probed with rabbit anti-mouse caspase- 3 or mouse anti- $\beta$-actin antibody. $\beta$-actin protein levels are shown as control for protein loading. Each blot represents one of two blots of three samples (each blot showed the same pattern of induction). 
Overexpressed CYP2A5 is functional in Hepa 1-6

To optimize the overexpression of CYP2A5 and POR proteins in Hepa 1-6, CYP2A5-V5 and POR-V5 expression plasmids were transfected into Hepa 1-6 cells in various combinations. Western blotting was used to determine the optimal amount of each expression plasmid for transfection. Figure 9a shows the last step of transfection optimization; $2.0 \mu \mathrm{g}$ of CYP2A5-V5 plasmid and $0.4 \mu \mathrm{g}$ of POR-V5 plasmid was required to have maximum expression in Hepa 1-6. To test if overexpressed CYP2A5-V5 proteins are functional, a 7-ethoxycoumarin deethylation assay was performed. Overexpression of CYP2A5-V5 alone significantly increased 7-ethoxycoumarin deethylation by 2 -fold $(P<0.001)$ relative to control (Figure $9 b)$. Furthermore, cotransfection of POR-V5 in addition to CYP2A5-V5 transfection significantly increased (3-fold; $P<0.0001$ ) the activity of CYP2A5-V5 protein in Hepa 1-6 (Figure 9c).

CYP2A5 overexpression partially blocks BR-induced caspase-3 activation in Hepa 1-6 cells

To test the hypothesis that CYP2A5 plays a cytoprotective role against BR toxicity, the effect of CYP2A5-V5 and POR-V5 overexpression in BR-induced caspase-3 cleavage was examined. Briefly, CYP2A5-V5 and POR-V5 expression plasmids were transfected into Hepa 1-6 for 24 hours, and the cells were treated with $50 \mu \mathrm{M}$ BR for another 24 hours. The total protein lysate from control and BR-treated cells were analyzed via Western blotting with anti-caspase-3 antibody. As previously shown, $50 \mu \mathrm{M}$ BR treatment activated caspase-3 cleavage by 13 -fold relative to control cells transfected with empty vector (pcDNA3.1) $(P<0.01)$ (Figure 10b). However, overexpression of 
CYP2A5-V5 and POR-V5 reduced caspase-3 cleavage by $40 \%$ to a level of 9 -fold $(P<$ 0.01 ) relative to control (Figure $10 \mathrm{~b})$.

B

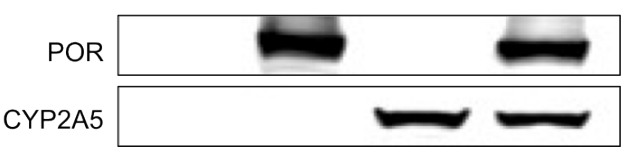

A

C
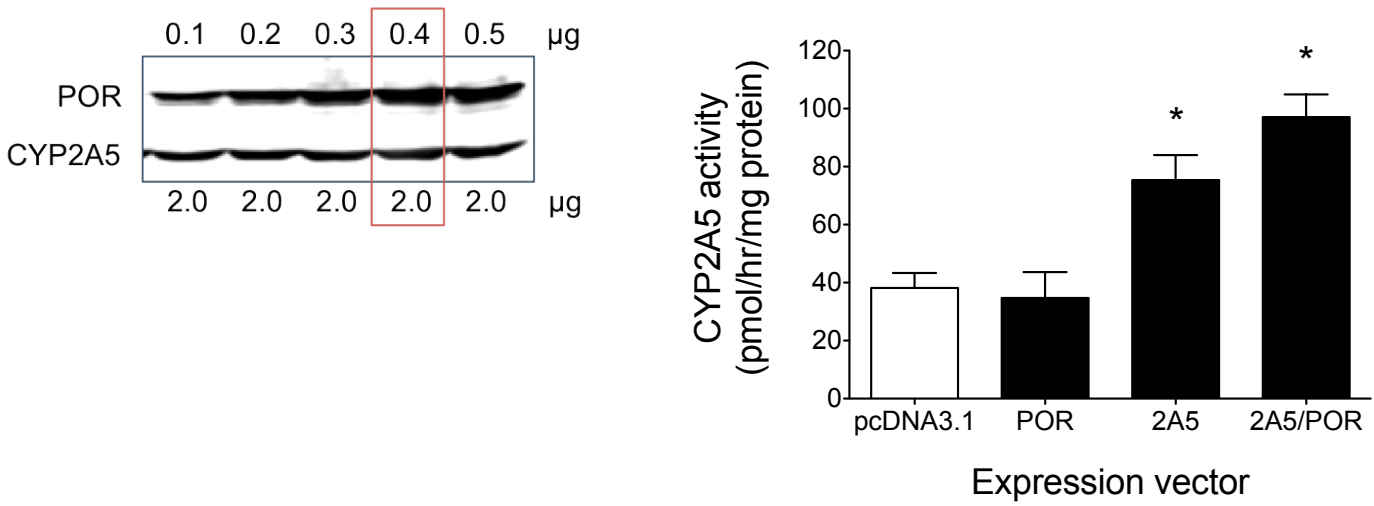

Figure 9. Optimization of transfection conditions for CYP2A5 overexpression in Hepa 16 cells. (A) Western blot showing the optimization of amount of expression vector required to overexpress CYP2A5 and POR protein in Hepa1-6 cells. (B) Western blot analysis of CYP2A5/POR protein. (C) CYP2A5 activity assessed by 7-ethoxycoumarin deethylation assay in Hepa1-6 cells overexpressing pcDNA3.1, control empty vector; POR, oxidoreductase alone; 2A5, CYP2A5 alone; 2A5/POR, co-transfection of both CYP2A5 and POR. All values represent the mean \pm SEM $(n=5$ independent experiments). Mean difference is significant from control group at $* P<0.0001$ (one-way repeated measures ANOVA followed by Dunnett's post-test). 

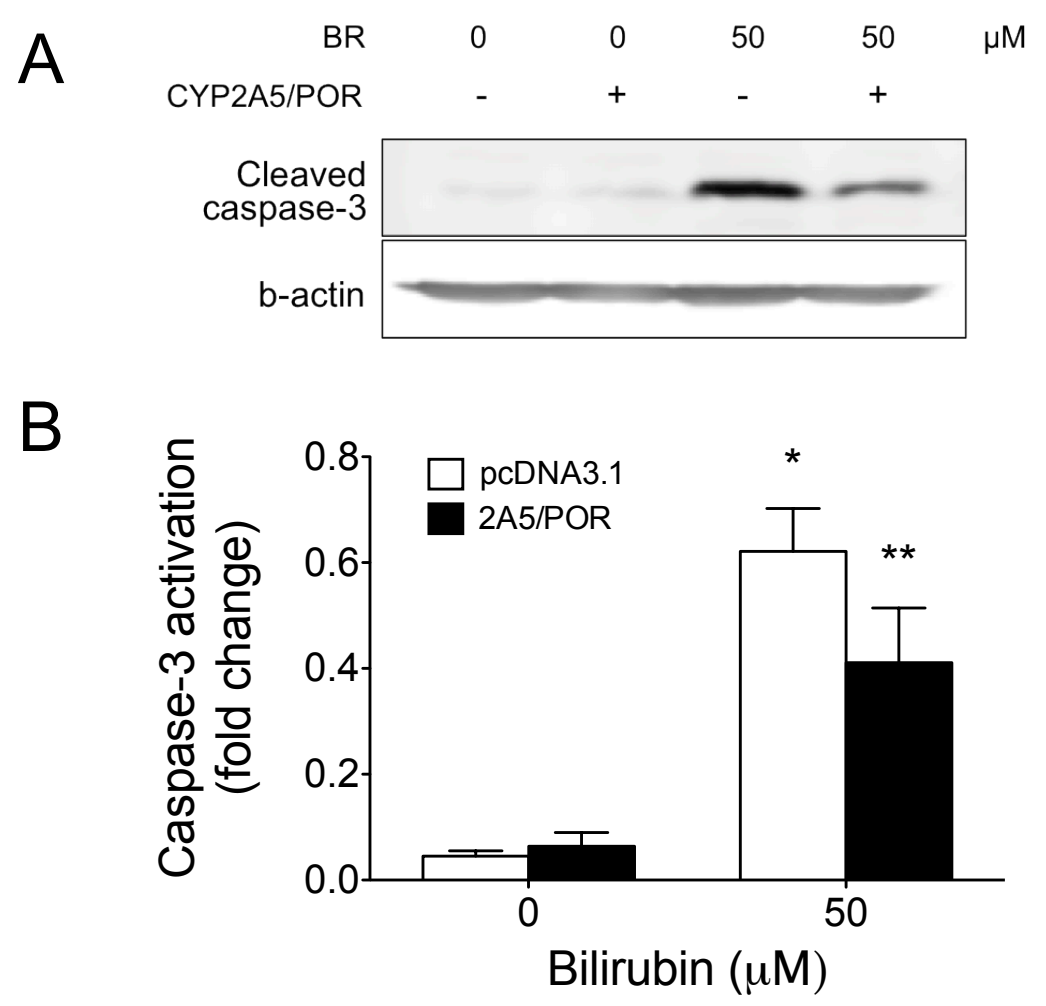

Figure 10. Effect of CYP2A5 and POR overexpression on BR-induced caspase-3 cleavage in Hepa 1-6 cells. Hepa 1-6 cells were transfected with CYP2A5 and POR for $24 \mathrm{~h}$ and treated with $50 \mu \mathrm{M} \mathrm{BR}$ for another $24 \mathrm{~h}$. (A) Western blot analysis of total protein ( $40 \mu \mathrm{g}$ total protein/lane) from control and BR-treated cells were probed with rabbit anti-mouse caspase- 3 or mouse anti- $\beta$-actin antibody. $\beta$-actin protein levels are shown as control for protein loading. Each blot represents one of two blots consisting of four replicates (each blot showed the same pattern of induction). (B) Densitometric quantification of Western blots. All values represent the mean $\pm \operatorname{SEM}(n=4$ independent experiments) normalized against the control levels. Mean differences are significant from control group at $* P<0.001$ (pcDNA3.1 compared to untreated control) and $* * P<0.01$ (CYP2A5/POR compared to pcDNA3.1 both treated; interaction) (two-way ANOVA followed by Bonferroni post-test). 
CYP2A5 overexpressing microsomes have increased BR degradation rate

In order to further investigate the mechanisms underlying the cytoprotective role of CYP2A5 against BR toxicity, we determined whether overexpressed CYP2A5-V5 metabolizes BR in Hepa 1-6 cells, using a BR disappearance assay as previously described (Abu-Bakar et al., 2011). Hepa 1-6 cells were transfected with pcDNA3.1 or CYP2A5-V5/POR-V5 expression plasmids, and microsomal fractions was prepared by ultracentrifugation. Proteins expressed by transfection of CYP2A5-V5/POR-V5 plasmids were localized only in microsomal protein as demonstrated in Figure 11a. BR (10 $\mu \mathrm{M})$ was incubated with either microsomes from cells transfected with either pcDNA3.1 or CYP2A5-V5/POR-V5, and the degradation rate was measured by spectrophotometry. CYP2A5-V5/POR-V5 overexpression significantly increased the BR clearance rate by 6.4-fold $(P<0.003)$ relative to control (Figure $11 \mathrm{~b})$. 
A

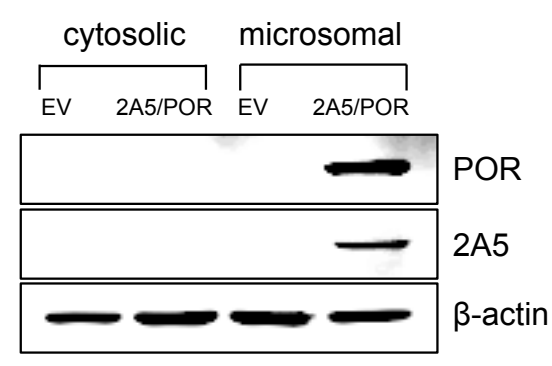

B

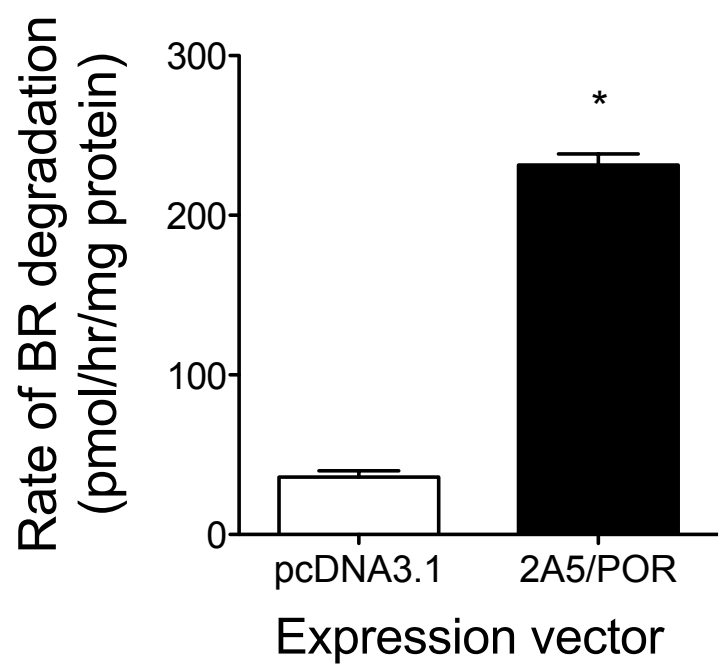

Figure 11. (A) Representative Western blot showing overexpression of CYP2A5 and POR is localized in the microsomal fraction of Hepa 1-6 cells. (B) The rate of BR degradation is increased in microsomes from Hepa 1-6 cells overexpressing 2A5/POR. Microsomes from Hepa 1-6 cells transfected with CYP2A5 and POR were incubated 10 $\mu \mathrm{M} \mathrm{BR}$ and the degradation rate was measured by spectrophotometry. All values represent the mean $\pm \operatorname{SEM}(\mathrm{n}=3$ independent experiments). Mean difference is significant from control group at $* P<0.003$ (Student's t-test). 


\section{DISCUSSION}

CYP2A5 plays an important role in detoxification of various xenobiotics and drugs. It is also implicated in protection against oxidative stress, which arises from various pathological states. Recently, BR has been identified as an endogenous substrate and inducer of CYP2A5 (Abu-Bakar et al., 2011). Abu-Bakar et al. (2011) demonstrated that CYP2A5 is an inducible BR oxidase that it converts BR into its precursor, biliverdin, which can be recovered back to BR by biliverdin reductase (Abu-Bakar et al., 2011). They suggested this system prevents the wasting of BR from glucuronidation by UGT1A1 and accumulation of BR in pro-oxidant levels (Abu-Bakar et al., 2011). Hence, the question that remains is to what extent BR metabolism by CYP2A5 can prevent the cytotoxic effects of excessive BR and how BR regulates CYP2A5. Therefore, the objective of this study is to investigate the role of CYP2A5 in bilirubin (BR) toxicity and the influence of BR on the regulatory mechanisms of Cyp $2 a 5$ gene expression. Our findings demonstrate that excessive BR induces CYP2A5 transcription resulting in increased mRNA and protein expression and that this induction requires Nrf2 activation in primary mouse hepatocytes. Furthermore, Hepa 1-6 cells overexpressing CYP2A5 protein are partially protected from BR toxicity through direct clearance of excessive BR.

CYP2A5 is known for its unique regulation. CYP2A5 is upregulated following exposure to chemical hepatotoxins and during pathophysiological conditions, in which the levels of most CYPs are either unchanged or downregulated (Juvonen et al., 1985; Camus et al., 1996; Kojo et al., 1998; Kirby et al., 2011). In the present study, BR at high-dose $(25$ and $50 \mu \mathrm{M})$ significantly induced CYP2A5 mRNA and protein expression 
in primary mouse hepatocytes in dose-dependent manner. Our result showing CYP2A5 mRNA induction by BR is in contrast to what was reported by Abu-Bakar et al. (2011) where CYP2A5 mRNA induction was not observed. This difference in CYP2A5 mRNA expression appears to be due to mouse strain differences. In the present study, primary hepatocytes were obtained from C57BL/6 mice whereas Abu-Bakar et al. (2011) used DBA/2J mice (Abu-Bakar et al., 2011). While both strains are widely used in drug metabolism studies, strain characteristics might explain differences in responsiveness to certain inducing agents. For example, differences in glutathione S-transferase activity (GST) may alter net uptake of BR by hepatocytes (Wolkoff et al., 1978, 2012; Higgins and Hayes, 2011). Furthermore, it has been reported that DBA/2 mice lack functional AhR (Poland and Glover, 1975; Okey et al., 1989), which is known to directly regulate the Nrf2 antioxidant pathway and upregulate xenobiotic detoxifying enzymes that are involved in oxidative stress response, cell cycle control, and apoptosis (Nebert et al., 2000; Miao et al., 2005). For example, 3-methylcholanthrene (3-MC) significantly induces microsomal GSTA1/2 protein expression in C57BL/6 mice and has little to no effect in DBA/2O mice (Higgins et al., 2008). Furthermore, the AhR agonist, $\beta$ naphthoflavone ( $\beta$-NF) increases GST activity significantly more in C57BL/6 mice than $\mathrm{DBA} / 2$ mice, due to the non-functional AhR in DBA/2 mice (Prochaska and Talalay, 1988; Mclellan et al., 1991).These reports suggest that DBA/2J mice may express relatively lower GSTA1/2 levels due to lack of functional AhR, which in turn may decrease BR net uptake by hepatocytes compared to C57BL/6 mice for the same dose of BR treatment. Therefore it is possible that BR accumulation in hepatocytes was not high enough to drive transcription of CYP2A5 in DBA/2J mice. Moreover, it could be simply 
due to the shorter length (6 h) of BR treatment that Abu-Bakar et al. (2011) used in their study. It is also important to note that semi-quantitative Northern blot analysis was used in their study, whereas real-time RT-PCR has been used in the present study. RT-PCR is a newer technique that is more reliable for quantitative analysis and has higher sensitivity and specificity (Bustin et al., 2005).

Our results, also show that BR induces CYP2A5 protein in a dose-dependent manner in agreement with findings by Abu-Bakar et al. (Abu-Bakar et al., 2011). Abu-Bakar et al. (2011) showed that co-treatment of cycloheximide (CHX) with BR, a protein synthesis inhibitor, resulted in an increased half-life of the CYP2A5 protein compared to cells treated only with CHX (Abu-Bakar et al., 2011) indicating that increased CYP2A5 protein levels are likely due to post-translational mechanism involving protein stabilization by BR. However, our findings that BR increases CYP2A5 mRNA and protein in a dose-dependent manner suggest that CYP2A5 induction may be due to either transcriptional or post-transcriptional mechanisms.

To investigate the underlying mechanism of CYP2A5 induction by BR, we performed a reporter assay using a luciferase reporter plasmid containing the Cyp2a5 5'untranslated promoter region from -3033 to $+10 \mathrm{bp}$. To date, a number of transcription factors and their response elements have been identified for CYP2A5 that play important roles in various cellular functions such as the stress and immune responses, cell cycle activation and cellular proliferation, and glucose and xenobiotic metabolism (Cai et al., 2002; Maglich et al., 2002; Abu-Bakar et al., 2004; Ulvila et al., 2004; Abu-bakar et al., 2007; Arpiainen et al., 2007, 2008). However, given that effects of high BR has been shown to be closely related to oxidative stress in various organelles, among the other 
transcription factors, Nrf2 appears to be involved in BR-mediated induction of CYP2A5. Nrf2 regulates the expression of genes involved in the glutathione synthesis, ROS clearance and xenobiotic metabolism (Itoh et al., 1999; Kamisako et al., 2000). Furthermore, recently the binding site for Nrf2, the stress responsive element (StRE) has been identified in the CYP2A5 promoter region, and the parent compound of $\mathrm{BR}$, heme has been shown to regulate Cyp2a5 via Nrf2 activation (Abu-bakar et al., 2007; Lämsä et al., 2012). Nrf2 has been also shown to regulate both constitutive and inducible expression of Cyp2a5 in response to oxidative stress (Abu-Bakar et al., 2004;

Dhakshinamoorthy and Porter, 2004; Purdom-dickinson et al., 2007; Lämsä et al., 2010). In the present study, to investigate the involvement of $\mathrm{Nrf} 2$ in the regulation of Cyp2a5 expression by BR, primary mouse hepatocytes were cotransfected with the CYP2A5 reporter construct and an Nrf2 expression vector. Nrf2 overexpression significantly induced Cyp2a5 reporter activity, and this increase was significantly augmented with BR treatment. BR did not increase CYP2A5 transcription in the absence of Nrf2 overexpression. Moreover, this BR-mediated increase in transcriptional activity in the presence of Nrf2 overexpression was abolished following site-directed mutation of StRE in the luciferase reporter construct. Hence, our results demonstrate Nrf2 is indeed required for CYP2A5 transcriptional activation by BR.

$\mathrm{BR}$ is shown to be toxic to many cell types and intracellular organelles at high concentrations (>20 $\mu \mathrm{M})$, and prolonged exposure and accumulation of BR can lead to cell damage or death (Roy-Chowdhury et al., 2007; McDonagh, 2010). Although the molecular mechanism underlying the cytotoxic effects of BR is unclear, previous reports show BR directly damages cell membranes at various levels, including mitochondria and 
ER membrane, disrupting their functions (Mayor et al., 1986; Silva et al., 2001; Brites and Brito, 2012). Furthermore, these cytotoxic effects of BR are shown to be mainly due to production of ROS resulting in protein oxidation, and lipid peroxidation (Brito et al., 2004, 2008a, 2008b; Kumar et al., 2008; Brites and Brito, 2012). Previous reports have demonstrated that BR can cause apoptosis via both intrinsic and extrinsic signaling pathways (Seubert et al., 2002; Vaz et al., 2011; Brites and Brito, 2012). BR also induces ER stress by disrupting intracellular calcium $\left(\mathrm{iCa}^{2+}\right)$ homeostasis and increasing $\mathrm{ROS}$ production resulting in activation of caspase-3 (Gao et al., 2011). Furthermore, DNA oxidation by BR-induced oxidative stress can also trigger apoptosis (Deganuto et al., 2010). Our results support previous findings by demonstrating that BR induces caspase-3 activation in both Hepa 1-6 and primary mouse hepatocytes.

In order to investigate the cytoprotective role of CYP2A5 against BR toxicity, we transiently overexpressed CYP2A5 protein in Hepa 1-6 cells, a cell line that lacks constitutive expression of CYP2A5. Our results demonstrate for the first time that transient overexpression of CYP2A5 partially protects against BR-induced apoptosis by decreasing BR-induced caspase-3 cleavage. It remains to be shown which apoptotic pathway is involved in BR-induced caspase- 3 cleavage. In the extrinsic pathway, apoptosis is initiated by the engagement of a transmembrane death receptor (i.e. Fas) by an extracellular ligand, which leads to the assembly of death-inducing signaling complex (DISC) (Riedl and Salvesen, 2007). DISC then activates the initiator caspase-8, which leads to subsequent activation of caspase-3/7 (Riedl and Salvesen, 2007). Previous studies have shown that caspase- 8 activity was significantly induced by BR treatment in Hepa 1c1c7 and rat neurons, suggesting BR-induced apoptosis is mediated by the 
extrinsic apoptosis pathway (Seubert et al., 2002; Vaz et al., 2011). However, caspase-8 induction appears to be cell-type specific, hence it remains unclear whether BR acts as a ligand for the death receptor or whether caspase- 8 activity is increased indirectly by BR via oxidative stress in cellular organelles (Keshavan et al., 2004).

In the intrinsic mitochondrial pathway, apoptosis is initiated by stimuli that lead to the permeabilization of the outer mitochondrial membrane and the release of cytochrome c, which forms the apoptosome with apoptotic protease activating factor 1(Apaf1) (Riedl and Salvesen, 2007; Ow et al., 2008). The apoptosome then activates caspase-9, and finally activates caspase-3/7 (Riedl and Salvesen, 2007; Ow et al., 2008). Previous reports have shown that BR treatment also induces cytochrome c release from mitochondria and activation of caspase-9 in various cell types (Seubert et al., 2002; Keshavan et al., 2004; Oakes and Bend, 2005). These effects by BR are mainly due to disruption of the mitochondrial membrane and production of ROS (Seubert et al., 2002; Keshavan et al., 2004; Oakes and Bend, 2005).

BR has been also shown to induce apoptosis via ER stress. BR treatment in synaptosomes increases $\mathrm{iCa}^{2+}$ and ROS production significantly (Brito et al., 2006). Increased $\mathrm{iCa}^{2+}$ disrupts intracellular homeostasis and produces more ROS, leading to ER stress (Brito et al., 2006; Brites and Brito, 2012). This can then lead to activation of caspase-2/12 and the dissociation of an ER luminal chaperone, the immunoglobulin heavy chain binding protein (Bip), which also initiates apoptosis (Brites and Brito, 2012). Barateiro et al. (2012) demonstrated that BR treatment in oligodendrocyte precursor cells induced $\mathrm{iCa}^{2+}$ overload and production of ROS, as well as activation of caspase- 2 and the ER stress marker glucose-regulated protein 78 (Barateiro et al., 2012). However, BR- 
induced apoptosis via ER stress has not been demonstrated in liver tissue and requires further investigation. Taken together, the exact underlying mechanism of BR-induced apoptosis in liver needs further investigation.

Finally, to determine whether the cytoprotective role of CYP2A5 overexpression in BR toxicity is due to direct clearance of BR, we have modified the BR degradation assay previously established (Abu-Bakar et al., 2005). Microsomes from Hepa 1-6 overexpressing CYP2A5 protein were isolated and used to assess BR degradation in vitro. We confirmed that transient transfection of CYP2A5 protein is localized to the microsomal fraction of Hepa 1-6 cells, and that degradation of BR by microsomes from these cells was significantly greater than by microsomes from cells transfected with the empty vector. This suggests that CYP2A5 overexpression protected against BR-induced apoptosis through BR oxidation into less toxic metabolites such as biliverdin as previously described (Abu-Bakar et al., 2011).

In conclusion, this thesis research examined the role of CYP2A5 in BR metabolism by investigating Cyp2a5 gene regulation by BR, and the cytoprotective role of CYP2A5 in BR toxicity. Our results demonstrate that BR induces CYP2A5 expression at the mRNA and protein levels by increasing CYP2A5 transcription via a mechanism that involves Nrf2 activation. Furthermore, our results suggest that induced CYP2A5 plays a cytoprotective role against BR toxicity by directly lowering the cellular levels of BR and by inhibiting caspase-3 activation. Previous studies have indicated that other enzymes involved in bilirubin metabolism such as UGT1A1 are also regulated by Nrf2 thereby reducing BR levels. For example, a recent study by Kundu et al. (2011) reported that a flavone glycoside, carlinoside, upregulates Nrf2 gene expression and increases its nuclear 
translocation and stimulated UGT1A1 promoter activity, which results in a significant increase of BR glucuronidation (Kundu et al., 2011). Therefore, this study suggests Nrf2mediated CYP2A5 induction in response to BR may provide an additional mechanism to adaptive response of our body against BR toxicity.

However, the question still remains why BR treatment alone did not alter luciferase activity in primary mouse hepatocytes. It is likely that the transfected Cyp2a5 5'-3033 reporter construct may not have been able to reach the nucleus while BR activates Nrf2 translocation into nucleus. Hence, whether BR actually activates Nrf2 translocation in primary mouse hepatocytes needs to be investigated. Furthermore, recent studies report that constitutive androstane receptor (CAR) also increases BR clearance (Huang et al., 2003, 2004). Therefore, given that previous studies have suggested CAR binding sites exist in CYP2A5 promoter, it would be compelling to investigate whether BR clearance by CYP2A 5 can be also mediated by CAR. 


\section{SUMMARY AND CONCLUSIONS}

This study investigated the mechanisms for gene regulation and a cytoprotective role of CYP2A5 in response to BR treatment in liver. Our results demonstrate that BR induces CYP2A5 expression at the mRNA and protein levels by increasing CYP2A5 transcription via a mechanism that involves Nrf2 activation. Furthermore, our results suggest that induced CYP2A5 plays a cytoprotective role against BR toxicity by directly lowering the cellular levels of BR and thereby inhibiting caspase-3 activation.

In the present study, BR at high dose significantly induced CYP2A5 mRNA and protein expression in primary hepatocytes in dose-dependent manner. This result showing CYP2A5 mRNA induction by BR is in contrast to what was previously reported by AbuBakar et al. (Abu-Bakar et al., 2011). This difference in CYP2A5 mRNA expression appears to be due to the following reasons (1) in our study, primary hepatocytes were obtained from C57BC/6 mice whereas Abu-Bakar et al. (2011) used DBA/2J mice. (2) The BR treatment length was shorter $(6 \mathrm{~h})$ in the study by Abu-Bakar et al. (2011) compared to our $24 \mathrm{~h}$ treatment. (3) Abu-Bakar et al. (2011) used semi-quantitative Northern blot analysis for CYP2A5 mRNA quantification whereas real-time RT-PCR has been used in the present study.

Our result also demonstrates that the induction of CYP2A5 mRNA and protein expression in primary hepatocytes is mediated by Nrf2 activation. However, whether BR treatment actually causes Nrf2 translocation in primary mouse hepatocytes needs to be further investigated. Moreover, Abu-Bakar et al. (2011) showed that co-treatment of CHX with BR resulted in an increased half-life of CYP2A5 protein compared to cells 
treated only with $\mathrm{CHX}$, suggesting that post-translational mechanism is also involved in the regulation of CYP2A5 by BR (Abu-Bakar et al., 2011). Furthermore, previous studies have demonstrated that the CAR also increases BR clearance (Huang et al., 2003, 2004). Previous studies have also suggested that the binding sites for CAR exist in CYP2A5 promoter (Cai et al., 2002; Maglich et al., 2002; Rosenfeld et al., 2003; Foretz et al., 2005) and we have shown that CAR is required for phenobarbital induction of CYP2A5 (Kirby et al., 2011). This suggests that CYP2A5 induction by BR is due to both transcriptional and post-transcriptional mechanisms, and CAR may also be involved.

Lastly, in order to investigate the cytoprotective role of CYP2A5 against BR toxicity, we examined the influence of transiently overexpressed CYP2A5 on BR-mediated apoptosis. Our results demonstrate for the first time that transient overexpression of CYP2A5 partially protects against BR-induced apoptosis by decreasing BR-induced caspase- 3 cleavage. However the exact underlying mechanism by which CYP2A5 protects against BR-induced apoptosis in mouse liver remains to be further investigated as previous reports show that BR induces apoptosis via various mechanisms (Seubert et al., 2002; Gao et al., 2011; Vaz et al., 2011; Brites and Brito, 2012).

We also confirmed that transient transfection of CYP2A5 protein is localized to the microsomal fraction of Hepa 1-6 cells, and that degradation of BR by microsomes from transfected cells was significantly greater than by microsomes from cells transfected with the empty vector. This suggests that CYP2A5 overexpression protects against BRinduced apoptosis via BR oxidation into less toxic metabolites such as biliverdin as previously demonstrated (Abu-Bakar et al., 2011). Therefore, this study suggests that 
Nrf2-mediated CYP2A5 induction in response to BR may provide an additional mechanism for the adaptive response against BR toxicity. 


\section{REFERENCE}

Abu-Bakar A, Arthur DM, Aganovic S, Ng JC, and Lang MA (2011) Inducible bilirubin oxidase: a novel function for the mouse cytochrome P450 2A5. Toxicology and Applied Pharmacology 257: 14-22.

Abu-Bakar A, Arthur DM, Wikman AS, Rahnasto M, Juvonen RO, Vepsäläinen J, Raunio H, Ng JC, and Lang MA (2012) Metabolism of bilirubin by human cytochrome P450 2A6. Toxicology and Applied Pharmacology.

Abu-Bakar A, Moore MR, and Lang MA (2005) Evidence for induced microsomal bilirubin degradation by cytochrome P450 2A5. Biochemical Pharmacology 70: 15271535.

Abu-Bakar A, Satarug S, Marks GC, Lang MA, and Moore MR (2004) Acute cadmium chloride administration induces hepatic and renal CYP2A5 mRNA, protein and activity in the mouse: involvement of transcription factor NRF2. Toxicology Letters 148: 199210.

Abu-bakar A, Virpi L, Arpiainen S, Moore MR, Lang MA, and Hakkola J (2007) Regulation of CYP2A5 Gene by the Transcription Factor Nuclear Factor (ErythroidDerived 2) -Like 2. Pharmacology 35: 787-794.

Aida K, and Negishi M (1991) Posttranscriptional regulation of coumarin 7-hydroxylase induction by xenobiotics in mouse liver: mRNA stabilization by pyrazole. Biochemistry 30: $8041-8045$.

Arpiainen S, Järvenpää S-M, Manninen A, Viitala P, Lang MA, Pelkonen O, and Hakkola J (2008) Coactivator PGC-1alpha regulates the fasting inducible xenobioticmetabolizing enzyme CYP2A5 in mouse primary hepatocytes. Toxicology and Applied Pharmacology 232: 135-141.

Arpiainen S, Lämsä V, Pelkonen O, Yim SH, Gonzalez FJ, and Hakkola J (2007) Aryl hydrocarbon receptor nuclear translocator and upstream stimulatory factor regulate Cytochrome P450 2a5 transcription through a common E-box site. Journal of Molecular Biology 369: 640-652.

Arpiainen S, Raffalli-Mathieu F, Lang MA, Pelkonen O, and Hakkola J (2005) Regulation of the Cyp2a5 Gene Involves an Aryl Hydrocarbon Receptor-Dependent Pathway. Molecular Pharmacology 67: 1325-1333.

Arvela P, Kraul H, Stenbäck F, and Pelkonen O (1991) The cerium-induced liver injury and oxidative drug metabolism in DBA/2 and C57BL/6 mice. Toxicology 69: 1-9.

Axelord J (1955) The enzymatic demethylation of ephedrine. The Journal of Pharmacology and Experimental Therapeutics 114: 430-438. 
Barateiro A, Vaz AR, Silva SL, Fernandes A, and Brites D (2012) ER Stress, Mitochondrial Dysfunction and Calpain/JNK Activation are Involved in Oligodendrocyte Precursor Cell Death by Unconjugated Bilirubin. Neuromolecular Medicine.

Bauer M, Hamm AC, Bonaus M, Jacob A, Jaekel J, Schorle H, Pankratz MJ, and Katzenberger JD (2004) Starvation response in mouse liver shows strong correlation with life-span-prolonging processes. Physiological Genomics 17: 230-244.

Berryl CS, Zarembo JE, and Ostrow JD (1972) Evidence for conversion of bilirubin to dihydroxyl derivatives in the Gunn rat. Biochemical and Biophysical Research Communications 49: 1366-1375.

Bhutani VK, Johnson L, and Sivieri EM (1999) Predictive ability of a Predischarge Hourspecific Serum Bilirubin for Subsequent Significant Hyperbilirubinemia in Healthy Term and Near-term Newborns. Pediatrics 103: 6-14.

Bonacini M (2004) Liver injury during highly active antiretroviral therapy: the effect of hepatitis C coinfection. Clinical Infectious Diseases 38 Suppl 2: S104-8.

Bonnett R, Davies JE, and Hursthouse MB (1976) Structure of bilirubin. Nature 262: 326-328.

Bosma PJ, Seppen J, Goldhoorn B, Bakker C, Elferink RPJO, Roy-Chowdhury J, RoyChowdhury N, and Jansen PL (1994) Bilirubin UDP-glucuronosyltransferase 1 is the only relevant bilirubin glucuronidating isoform in man. The Journal of Biological Chemistry 269: 17960-17964.

Brites D, and Brito MA (2012) Bilirubin Toxicity. In Neonatal Jaundice, pp. 115-144.

Brito MA, Brites D, and Butterfield DA (2004) A link between hyperbilirubinemia, oxidative stress and injury to neocortical synaptosomes. Brain Research 1026: 33-43.

Brito MA, Lima S, Fernandes A, Falcão AS, Silva RFM, Butterfield DA, and Brites D (2008a) Bilirubin injury to neurons: contribution of oxidative stress and rescue by glycoursodeoxycholic acid. Neurotoxicology 29: 259-269.

Brito MA, Rosa AI, Falcão AS, Fernandes A, Silva RFM, Butterfield DA, and Brites D (2008b) Unconjugated bilirubin differentially affects the redox status of neuronal and astroglial cells. Neurobiology of Disease 29: 30-40.

Brito MA, Rosa AI, Silva RFM, Falcão AS, Fernandes A, and Brites D (2007) Oxidative Stress and Disruption of the Nervous Cell.

Brito MA, Silva RFM, and Brites D (2002) Bilirubin induces loss of membrane lipids and exposure of phosphatidylserine in human erythrocytes. Cell Biology and Toxicology 18: $181-192$. 
Brito MA, Silva RFM, and Brites D (2006) Cell Response to Hyperbilirubinemia: A Journey along Key Molecular Events.

Briz O, Serrano M a, MacIas RIR, Gonzalez-Gallego J, and Marin JJG (2003) Role of organic anion-transporting polypeptides, OATP-A, OATP-C and OATP-8, in the human placenta-maternal liver tandem excretory pathway for foetal bilirubin. The Biochemical Journal 371: 897-905.

Brodie BB, Axelord J, Cooper JR, Gaudette L, La Du BN, Mitoma C, and Udenfriend S (1955) Detoxication of Drugs and Other Foreign Compounds by Liver Microsomes. Science 121: 603-604.

Bustin S a, Benes V, Nolan T, and Pfaffl MW (2005) Quantitative real-time RT-PCR - a perspective. Journal of Molecular Endocrinology 34: 597-601.

Cai Y, Konishi T, Han G, Campwala KH, French SW, and Wan Y-JY (2002) The role of hepatocyte RXR alpha in xenobiotic-sensing nuclear receptor-mediated pathways. European Journal of Pharmaceutical Sciences 15: 89-96.

Calligaris R, Bellarosa C, Foti R, Roncaglia PJ, Giraudi P, Krmac H, Tiribelli C, and Gustincich S (2009) A transcriptome analysis identifies molecular effectors of unconjugated bilirubin in human neuroblastoma SH-SY5Y cells. BMC Genomics 10: 543.

Camus A-M, Geneste O, Honkakoski P, Béréziat J-C, Henderson CJ, Wolf CR, Bartsch $\mathrm{H}$, and Lang MA (1993) High variability of nitrosamine metabolism among individuals: role of cytochromes P450 2A6 and 2E1 in the dealkylation of N-nitrosodimethylamine and N-nitrosodiethylamine in mice and humans. Molecular Carcinogenesis 7: 268-275.

Camus A-M, Raffalli F, Béréziat J-C, McGregor D, Konstandi M, and Lang MA (1996) Liver injury and expression of cytochromes P450: evidence that regulation of CYP2A5 is different from that of other major xenobiotic metabolizing CYP enzymes. Toxicology and Applied Pharmacology 138: 140-148.

Cesaratto L, Calligaris SD, Vascotto C, Deganuto M, Bellarosa C, Quadrifoglio F, Ostrow JD, Tiribelli C, and Tell G (2007) Bilirubin-induced cell toxicity involves PTEN activation through an APE1/Ref-1-dependent pathway. Journal of Molecular Medicine 85: 1099-1112.

Chemin I, Takahashi S, Belloc C, Lang MA, Ando K, Guidotti LG, Chisari F V, and Wild CP (1996) Differential induction of carcinogen metabolizing enzymes in a transgenic mouse model of fulminant hepatitis. Hepatology 24: 649-656.

Chen D, Lepar G, and Kemper B (1994) A transcriptional regulatory element common to a large family of hepatic cytochrome P450 genes is a functional binding site of the orphan receptor HNF-4. The Journal of Biological Chemistry 269: 5420-5427. 
Chen J, and Siddiqui A (2007) Hepatitis B virus X protein stimulates the mitochondrial translocation of Raf-1 via oxidative stress. Journal of Virology 81: 6757-6760.

Cheung C, Akiyama TE, Kudo G, and Gonzalez FJ (2003) Hepatic expression of cytochrome P450s in hepatocyte nuclear factor 1-alpha (HNF1 $\alpha$ )-deficient mice. Biochemical Pharmacology 66: 2011-2020.

Choi AMK, and Alam J (1996) Heme oxygenase-1: function, regulation, and implication of a novel stress-inducible protein in oxidant-induced lung injury. American Journal of Respiratory Cell and Molecular Biology 15: 9-19.

Chomarat P, Sipowicz MA, Diwan BA, Fornwald LW, Awasthi YC, Anver MR, Rice JM, Anderson LM, and Wild CP (1997) Distinct time courses of increase in cytochromes P450 1A2, 2A5 and glutathione S-transferases during the progressive hepatitis associated with Helicobacter hepaticus. Carcinogenesis 18: 2179-2190.

Corre S, and Galibert M-D (2005) Upstream stimulating factors: highly versatile stressresponsive transcription factors. Pigment Cell Research 18: 337-348.

Cullinan SB, Gordan JD, Jin J, Wade J, Diehl JA, and Harper JW (2004) The Keap1BTB Protein Is an Adaptor That Bridges Nrf2 to a Cul3-Based E3 Ligase : Oxidative Stress Sensing by a Cul3-Keap1 Ligase. Molecular and Cellular Biology 24: 8477-8486.

Dailly E, Urien S, Barré J, Reinert P, and Tillement JP (1998) Role of bilirubin in the regulation of the total peroxyl radical trapping antioxidant activity of plasma in sickle cell disease. Biochemical and Biophysical Research Communications 248: 303-306.

De-Oliveira AC a X, Carvalho RS, Paixão FHM, Tavares HS, Gueiros LS, Siqueira CM, and Paumgartten FJR (2010) Up- and down-modulation of liver cytochrome P450 activities and associated events in two murine malaria models. Malaria Journal 9: 81.

De-Oliveira AC a X, Da-Matta AC, and Paumgartten FJR (2006) Plasmodium berghei (ANKA): infection induces CYP2A5 and 2E1 while depressing other CYP isoforms in the mouse liver. Experimental Parasitology 113: 256-261.

Deganuto M, Cesaratto L, Bellarosa C, Calligaris R, Vilotti S, Renzone G, Foti R, Scaloni A, Gustincich S, Quadrifoglio F, et al. (2010) A proteomic approach to the bilirubin-induced toxicity in neuronal cells reveals a protective function of DJ-1 protein. Proteomics 10: 1645-1657.

Dennery PA, McDonagh AF, Spitz DR, Rodgers PA, and Stevenson DK (1995) Hyperbilirubinemia results in reduced oxidative injury in neonatal gunn rats exposed to hyperoxia. Free Radical Biology \& Medicine 19: 395-404.

Dhakshinamoorthy S, and Porter AG (2004) Nitric oxide-induced transcriptional upregulation of protective genes by Nrf2 via the antioxidant response element counteracts 
apoptosis of neuroblastoma cells. The Journal of Biological Chemistry 279: 2009620107.

Donato MT, Viitala P, Rodriguez-Antona C, Lindfors A, Castell J V, Raunio H, GomezLechon MJ, and Pelkonen O (2000) CYP2A5 / CYP2A6 EXPRESSION IN MOUSE AND HUMAN HEPATOCYTES TREATED WITH VARIOUS IN VIVO INDUCERS. Drug Metabolism and Disposition 28: 1321-1326.

Doré S, Takahashi M, Ferris C, Hester LD, Guastella D, and Snyder SH (1999) Bilirubin, formed by activation of heme oxygenase-2, protects neurons against oxidative stress injury. Proceedings of the National Academy of Sciences of the United States of America 96: $2445-2450$.

Felicia ND, Rekha GK, and Murphy SE (2000) Characterization of cytochrome P450 2A4 and 2A5-catalyzed 4-(methylnitrosamino)-1-(3-pyridyl)-1-butanone (NNK) metabolism. Archives of Biochemistry and Biophysics 384: 418-424.

Fisher CD, Lickteig AJ, Augustine LM, Ranger-moore J, Jackson JP, Ferguson SS, and Cherrington NJ (2009) Hepatic Cytochrome P450 Enzyme Alterations in Humans with Progressive Stages of Nonalcoholic Fatty Liver Disease. Drug Metabolism and Disposition 37: 2087-2094.

Foretz M, Ancellin N, Andreelli F, Saintillan Y, Grondin P, Kahn A, Thorens B, Vaulont S, and Viollet B (2005) Short-term overexpression of a constitutively active form of AMP-activated protein kinase in the liver leads to mild hypoglycemia and fatty liver. Diabetes 54: 1331-1339.

Gao X, Yang X, and Zhang B (2011) Neuroprotection of taurine against bilirubininduced elevation of apoptosis and intracellular free calcium ion in vivo. Toxicology Mechanisms and Methods 21: 383-387.

Garfinkel D (1958) Studies on pig liver microsomes. I. Enzymic and pigment composition of different microsomal fractions. Archives of Biochemistry and Biophysics 77: 493-509.

Gazzin S, Zelenka J, Zdrahalova L, Konickova R, Zabetta CC, Giraudi PJ, Berengeno AL, Raseni A, Robert MC, Vítek L, et al. (2012) Bilirubin accumulation and Cyp mRNA expression in selected brain regions of jaundiced Gunn rat pups. Pediatric Research.

Genter MB, Clay CD, Dalton TP, Dong H, Nebert DW, and Shertzer HG (2006) Comparison of mouse hepatic mitochondrial versus microsomal cytochromes $\mathrm{P} 450$ following TCDD treatment. Biochemical and Biophysical Research Communications 342: $1375-1381$. 
Genter MB, Liang HC, Gu J, Ding X, Negishi M, McKinnon R a, and Nebert DW (1998) Role of CYP2A5 and 2G1 in acetaminophen metabolism and toxicity in the olfactory mucosa of the Cyp1a2(-/-) mouse. Biochemical Pharmacology 55: 1819-1826.

Gilmore WJ, Hartmann G, Piquette-Miller M, Marriott J, and Kirby GM (2003) Effects of lipopolysaccharide-stimulated inflammation and pyrazole-mediated hepatocellular injury on mouse hepatic Cyp2a5 expression. Toxicology 184: 211-226.

Gilmore WJ, and Kirby GM (2004) Endoplasmic Reticulum Stress Due to Altered Cellular Redox Status Positively Regulates Murine Hepatic CYP2A5 Expression. The Journal of Pharmacology and Experimental Therapeutics 308: 600-608.

Glisovic T, Ben-David Y, Lang MA, and Raffalli-Mathieu F (2003) Interplay between hnRNP A1 and a cis-acting element in the 3' UTR of CYP2A5 mRNA is central for high expression of the gene. FEBS Letters 535: 147-152.

Goodwin B, Hodgson E, and Liddle C (1999) The orphan human pregnane X receptor mediates the transcriptional activation of CYP3A4 by rifampicin through a distal enhancer module. Molecular Pharmacology 56: 1329-1339.

De Graaf W, Häusler S, Heger M, Van Ginhoven TM, Van Cappellen G, Bennink RJ, Kullak-Ublick G a, Hesselmann R, Van Gulik TM, and Stieger B (2011) Transporters involved in the hepatic uptake of $(99 \mathrm{~m}) \mathrm{Tc}-\mathrm{mebrofenin}$ and indocyanine green. Journal of Hepatology 54: 738-745.

Granato a, Gores G, Vilei MT, Tolando R, Ferraresso C, and Muraca M (2003) Bilirubin inhibits bile acid induced apoptosis in rat hepatocytes. Gut 52: 1774-1778.

Grandchamp B, Bissell DM, Licko V, and Schmid R (1981) Formation and disposition of newly synthesized heme in adult rat hepatocytes in primary culture. The Journal of Biological Chemistry 256: 11677-11683.

Guengerich FP (2001) Common and uncommon cytochrome P450 reactions related to metabolism and chemical toxicity. Chemical Research in Toxicology 14: 611-650.

Guengerich FP (2008) Cytochrome p450 and chemical toxicology. Chemical Research in Toxicology 21: 70-83.

Hahnemann B, Salonpää P, Pasanen M, Maenpaa J, Honkakoski P, Juvonen RO, Lang MA, Pelkonen O, and Raunio H (1992) Effect of pyrazole, cobalt and phenobarbital on mouse liver. Biochemical Journal 286: 289-294.

Hansen TWR (2010) Core Concepts: Bilirubin Metabolism. NeoReviews 11: e316-e322. 
Hatfield GL, and Barclay LRC (2004) Bilirubin as an antioxidant: kinetic studies of the reaction of bilirubin with peroxyl radicals in solution, micelles, and lipid bilayers.

Organic Letters 6: 1539-1542.

Higgins LG, Cavin C, Itoh K, Yamamoto M, and Hayes JD (2008) Induction of cancer chemopreventive enzymes by coffee is mediated by transcription factor Nrf2. Evidence that the coffee-specific diterpenes cafestol and kahweol confer protection against acrolein. Toxicology and Applied Pharmacology 226: 328-337.

Higgins LG, and Hayes JD (2011) Mechanisms of induction of cytosolic and microsomal glutathione transferase (GST) genes by xenobiotics and pro-inflammatory agents. Drug Metabolism Reviews 43: 92-137.

Hoffman EC, Reyes H, Chu F-F, Sander F, Conley LH, Brooks BA, and Hankinson O (1991) Cloning of a factor required for activity of the Ah (dioxin) receptor. Science 252: 954-958.

Honkakoski P, Kojo A, Raunio H, Pasanen M, Juvonen RO, and Lang MA (1988) Hepatic Mitochondrial Coumarin 7-Hydroxylase : Comparison with the Microsomal Enzyme The specific activity of cytochrome P450-linked coumarin 7-hydroxylase ( $\mathrm{COH}$ ) of he- patic mitoplasts from DBA / BN mice is up to $55 \%$ as great as the microsomal activit. Archives of Biochemistry and Biophysics 267: 558-567.

Honkakoski P, Zelko I, Sueyoshi T, and Negishi M (1998) The Nuclear Orphan Receptor CAR-Retinoid X Receptor Heterodimer Activates the Phenobarbital-Responsive Enhancer Module of the CYP2B Gene. Molecular and Cellular Biology 18: 5652-5658.

Huang W, Zhang J, Chua SS, Qatanani M, Han Y, Granata R, and Moore DD (2003) Induction of bilirubin clearance by the constitutive androstane receptor (CAR).

Proceedings of the National Academy of Sciences of the United States of America 100: 4156-4161.

Huang W, Zhang J, and Moore DD (2004) A traditional herbal medicine enhances bilirubin clearance by activating the nuclear receptor CAR. The Journal of Clinical Investigation 113: 137-143.

Iersel M Van, Walters D., Price RJ, Lovell D., and Lake B. (1994) Sex and strain differences in mouse hepatic microsomal coumarin 7-hydroxylase activity. Food and Chemical Toxicology 32: 387-390.

Itoh K, Chiba T, Takahashi S, Ishii T, Igarashi K, Katoh Y, Oyake T, Hayashi N, Satoh K, Hatayama I, et al. (1997) An Nrf2/small Maf heterodimer mediates the induction of phase II detoxifying enzyme genes through antioxidant response elements. Biochemical and Biophysical Research Communications 236: 313-322. 
Itoh K, Wakabayashi N, Katoh Y, Ishii T, Igarashi K, Engel JD, and Yamamoto M (1999) Keap1 represses nuclear activation of antioxidant responsive elements by Nrf2 through binding to the amino-terminal Neh2 domain. Genes \& Development 13: 76-86.

Joshi M, Billing BH, and Hallinan T (1995) Investigation of the role of reactive oxygen species in bilirubin metabolism in the Gunn rat. Biochimica Et Biophysica Acta 1243: 244-250.

Jounaïdi Y, Bonfils C, Périn F, Negishi M, and Lange R (1994) Overexpression of a cytochrome P-450 of the 2a family (Cyp2a-5) in chemically induced hepatomas from female mice. European Journal of Biochemistry / FEBS 219: 791-798.

Juvonen RO, Kaipainen PK, and Lang MA (1985) Selective induction of coumarin 7hydroxylase by pyrazole in D2 mice. European Journal of Biochemistry / FEBS 152: 3 8 .

Juvonen RO, Shkumatov VM, and Lang MA (1988) Purification and characterization of a liver microsomal cytochrome P-450 isoenzyme with a high affinity and metabolic capacity for coumarin from pyrazole-treated D2 mice. European Journal of Biochemistry / FEBS 171: 205-211.

Kamisaka K, Gatmaitan Z, Moore CL, and Arias IM (1975) Ligandin reverses bilirubin inhibition of liver mitochondrial respiration in vitro. Pediatric Research 9: 903-905.

Kamisako T, Kobayashi Y, Takeuchi K, Ishihara T, Higuchi K, Tanaka Y, Gabazza EC, and Adachi Y (2000) Recent advances in bilirubin metabolism research: the molecular mechanism of hepatocyte bilirubin transport and its clinical relevance. Journal of Gastroenterology 35: 659-664.

Kapitulnik J, and Ostrow JD (1978) Stimulation of bilirubin catabolism in jaundiced Gunn rats by an induced of microsomal mixed-function monooxygenases. Proceedings of the National Academy of Sciences of the United States of America 75: 682-685.

Kataoka K, Noda M, and Nishizawa M (1994) Maf nuclear oncoprotein recognizes sequences related to an AP-1 site and forms heterodimers with both Fos and Jun. Molecular and Cellular Biology 14: 700-712.

Kaufman RJ (2002) Orchestrating the unfolded protein response in health and disease. The Journal of Clinical Investigation 110: 1389-1398.

Keshavan P, Schwemberger SJ, Smith DLH, Babcock GF, and Zucker SD (2004) Unconjugated bilirubin induces apoptosis in colon cancer cells by triggering mitochondrial depolarization. International Journal of Cancer 112: 433-445.

Kirby GM, Batist G, Alpert L, Lamoureux E, Cameron RG, and Alaoui-Jamali MA (1996) Overexpression of Cytochrome P-450 Isoforms Involved in Aflatoxin B1 
Bioactivation in Human Liver with Cirrhosis and Hepatitis. Toxicologic Pathology 24: $458-467$.

Kirby GM, Chemin I, Montesano R, Chisari F V, Lang MA, and Wild CP (1994a) Induction of specific cytochrome P450s involved in aflatoxin B1 metabolism in hepatitis $\mathrm{B}$ virus transgenic mice. Molecular Carcinogenesis 11: 74-80.

Kirby GM, Nichols KD, and Antenos M (2011) CYP2A5 Induction and Hepatocellular Stress: An Adaptive Response to Perturbations of Heme Homeostasis. Current Drug Metabolism 12: 186-197.

Kirby GM, Pelkonen P, Vanchai V, Camus A-M, Christopher P, and Lang MA (1994b) Association of Liver Fluke (Opisthorchis viverrini) Infestation with Increased Expression of Cytochrome P450 and Carcinogen Metabolism in Male Hamster Liver. Molecular Carcinogenesis 89: 81-89.

Klingenberg M (2003) Pigments of rat liver microsomes. Archives of Biochemistry and Biophysics 409: 2-6.

Kobayashi A, Kang M, Okawa H, Zenke Y, Chiba T, Igarashi K, and Ohtsuji M (2004) Oxidative Stress Sensor Keap1 Functions as an Adaptor for Cul3-Based E3 Ligase To Regulate Proteasomal Degradation of Nrf2. Molecular and Cellular Biology 24: 7130 7139.

Kobayashi M, and Yamamoto M (2006) Nrf2-Keap1 regulation of cellular defense mechanisms against electrophiles and reactive oxygen species. Advances in Enzyme Regulation 46: 113-140.

Kocer Z, Raunio H, Pasanen M, Arvela P, Raiskila T, Honkakoski P, Lang MA, Negishi M, and Pelkonen O (1991) Comparison between cobalt and pyrazole in the increased expression of coumarin 7-hydroxylase in mouse liver. Biochemical Pharmacology 41: $462-465$.

Kojo A, Viitala P, Pasanen M, Pelkonen O, Raunio H, and Juvonen RO (1998) Induction of CYP2A5 by pyrazole and its derivatives in mouse primary hepatocytes. Archives of Toxicology 72: 336-341.

Konno Y, Negishi M, and Kodama S (2008) The Roles of Nuclear Receptors CAR and PXR in Hepatic Energy Metabolism. Drug Metabolism and Pharmacokinetics 23: 8-13.

Kumar S, Guha M, Choubey V, Maity P, Srivastava K, Puri SK, and Bandyopadhyay U (2008) Bilirubin inhibits Plasmodium falciparum growth through the generation of reactive oxygen species. Free Radical Biology \& Medicine 44: 602-613.

Kundu R, Dasgupta S, Biswas A, Bhattacharya S, Pal BC, Bhattacharya S, Rao PG, Barua NC, Bordoloi M, and Bhattacharya S (2011) Carlinoside reduces hepatic bilirubin 
accumulation by stimulating bilirubin-UGT activity through Nrf2 gene expression. Biochemical Pharmacology 82: 1186-1197.

Levi a J, Gatmaitan Z, and Arias IM (1969) Two hepatic cytoplasmic protein fractions, Y and Z, and their possible role in the hepatic uptake of bilirubin, sulfobromophthalein, and other anions. The Journal of Clinical Investigation 48: 2156-2167.

Lu Y, Zhuge J, Wu D, and Cederbaum AI (2010) Ethanol Induction of CYP2A5 : Permissive Role for CYP2E1. Drug Metabolism and Disposition 39: 330-336.

Lämsä V, Levonen A-L, Leinonen H, Ylä-Herttuala S, Yamamoto M, and Hakkola J (2010) Cytochrome P450 2A5 constitutive expression and induction by heavy metals is dependent on redox-sensitive transcription factor Nrf2 in liver. Chemical Research in Toxicology 23: 977-985.

Lämsä V, Levonen A-L, Sormunen R, Yamamoto M, and Hakkola J (2012) Heme and heme biosynthesis intermediates induce Heme oxygenase-1 and Cytochrome P450 2A5, enzymes with putative sequential roles in heme and bilirubin metabolism: Different requirement for transcription factor Nuclear factor erythroid-derived 2-like 2.

Toxicological Sciences : An Official Journal of the Society of Toxicology.

Maglich JM, Parks DJ, Moore LB, Collins JL, Goodwin B, Billin AN, Stoltz CA, Kliewer S a, Lambert MH, Willson TM, et al. (2003) Identification of a novel human constitutive androstane receptor (CAR) agonist and its use in the identification of CAR target genes. The Journal of Biological Chemistry 278: 17277-17283.

Maglich JM, Stoltz CM, Goodwin B, Hawkins-Brown D, Moore JT, and Kliewer S a (2002) Nuclear pregnane $\mathrm{x}$ receptor and constitutive androstane receptor regulate overlapping but distinct sets of genes involved in xenobiotic detoxification. Molecular Pharmacology 62: 638-646.

Malaguarnera L, Madeddu R, Palio E, Arena N, and Malaguarnera M (2005) Heme oxygenase-1 levels and oxidative stress-related parameters in non-alcoholic fatty liver disease patients. Journal of Hepatology 42: 585-591.

Mangoura SA, Strack A, Legrum W, and Netter KJ (1989) Indium selectively increases the cytochrome P-450 dependent O-dealkylation of coumarin derivatives in male mice. Archives of Pharmacology 339: 596-602.

Matteis F DE, Dawson SJ, Boobis AR, and Comoglio A (1991) Inducible BilirubinDegrading System of Rat Liver Microsomes: Role of Cytochrome P4501A1. Molecular Pharmacology 40: 686-691.

Matteis F De, Lord GA, Lim CK, and Pons N (2006) Bilirubin degradation by uncoupled cytochrome P450 . Comparison with a chemical oxidation system and characterization of 
the products by high-performance liquid chromatography / electrospray ionization mass spectrometry. Rapid Communications in Mass Spectrometry 20: 1209-1217.

Matteis F DE, Trenti T, Gibbs AH, and Greig JB (1989) Inducible Bilirubin-Degrading of Rat Liver System in the Microsomal Fraction. Molecular Pharmacology 35: 831-838.

Mayor F, Díez-Guerra J, and Valdivieso F (1986) Effect of bilirubin on the membrane potential of rat brain synaptosomes. Journal of Neurochemistry 47: 363-369.

McDonagh AF (2010) Controversies in bilirubin biochemistry and their clinical relevance. Seminars in Fetal \& Neonatal Medicine 15: 141-147.

Mclellan LI, Kerr LA, Cronshawt AD, and Hayes JD (1991) Regulation of mouse glutathione S-transferases by chemoprotectors. Biochemical Journal 276: 461-469.

McMahon M, Itoh K, Yamamoto M, and Hayes JD (2003) Keap1-dependent proteasomal degradation of transcription factor Nrf2 contributes to the negative regulation of antioxidant response element-driven gene expression. The Journal of Biological Chemistry 278: 21592-21600.

Mermod N, O’Neill EA, Kelly TJ, and Tjian R (1989) The proline-rich transcriptional activator of CTF/NF-I is distinct from the replication and DNA binding domain. Cell 58: $741-753$.

Meyer UA (1996) Overview of enzymes of drug metabolism. Journal of Pharmacokinetics and Biopharmaceutics 24: 449-459.

Miao W, Hu L, Scrivens PJ, and Batist G (2005) Transcriptional regulation of NF-E2 p45-related factor (NRF2) expression by the aryl hydrocarbon receptor-xenobiotic response element signaling pathway: direct cross-talk between phase I and II drugmetabolizing enzymes. The Journal of Biological Chemistry 280: 20340-20348.

Montero R, Gentile GJ, Frederick L, McMannis J, Murphy T, Silva G, Blankespoor H, and Gentile JM (1999) Induced expression of CYP2A5 in inflamed trematode-infested mouse liver. Mutagenesis 14: 217-220.

Moreau A, Vilarem MJ, Maurel P, and Pascussi JM (2007) Xenoreceptors CAR and PXR Activation and Consequences on Lipid Metabolism, Glucose Homeostasis, and Inflammatory Response. Molecular Pharmaceutics 5: 35-41.

Nebert DW, Roe a L, Dieter MZ, Solis W a, Yang Y, and Dalton TP (2000) Role of the aromatic hydrocarbon receptor and $[\mathrm{Ah}]$ gene battery in the oxidative stress response, cell cycle control, and apoptosis. Biochemical Pharmacology 59: 65-85.

Nelson DR, Koymans L, Kamataki T, Stegeman JJ, Feyereisen R, Waxman DJ, Waterman MR, Gotoh O, Coon MJ, Estabrook RW, et al. (1996) P450 superfamily: 
update on new sequences, gene mapping, accession numbers and nomenclature. Pharmacogenetics and Genomics 6: .

Neuzil J, and Stocker R (1994) Free and Albumin-bound Bilirubin Are Efficient Coantioxidants for a-Tocopherol, Inhibiting Plasma and Low Density Lipoprotein Lipid Peroxidation. The Journal of Biological Chemistry 269: 16712-16719.

Nguyen N, Bonzo J a, Chen S, Chouinard S, Kelner MJ, Hardiman G, Bélanger A, and Tukey RH (2008) Disruption of the ugt1 locus in mice resembles human Crigler-Najjar type I disease. The Journal of Biological Chemistry 283: 7901-7911.

Nichols KD, and Kirby GM (2008) Microarray analysis of hepatic gene expression in pyrazole-mediated hepatotoxicity: identification of potential stimuli of Cyp2a5 induction. Biochemical Pharmacology 75: 538-551.

Oakes GH, and Bend JR (2005) Early steps in bilirubin-mediated apoptosis in murine hepatoma (Hepa 1c1c7) cells are characterized by aryl hydrocarbon receptor-independent oxidative stress and activation of the mitochondrial pathway. Journal of Biochemical and Molecular Toxicology 19: 244-255.

Oakes GH, and Bend JR (2010) Global changes in gene regulation demonstrate that unconjugated bilirubin is able to upregulate and activate select components of the endoplasmic reticulum stress response pathway. Journal of Biochemical and Molecular Toxicology 24: 73-88.

Okawa H, Motohashi H, Kobayashi A, Aburatani H, Kensler TW, and Yamamoto M (2006) Hepatocyte-specific deletion of the keap1 gene activates Nrf2 and confers potent resistance against acute drug toxicity. Biochemical and Biophysical Research Communications 339: 79-88.

Okey AB, Vella LM, and Harper P a (1989) Detection and characterization of a low affinity form of cytosolic Ah receptor in livers of mice nonresponsive to induction of cytochrome P1-450 by 3-methylcholanthrene. Molecular Pharmacology 35: 823-830.

Ollinger R, Bilban M, Erat A, Froio A, McDaid J, Tyagi S, Csizmadia E, Graça-Souza A V, Liloia A, Soares MP, et al. (2005) Bilirubin: a natural inhibitor of vascular smooth muscle cell proliferation. Circulation 112: 1030-1039.

Ollinger R, Kogler P, Troppmair J, Hermann M, Wurm M, Drasche A, Königsrainer I, Amberger A, Weiss H, Ofner D, et al. (2007) Bilirubin inhibits tumor cell growth via activation of ERK. Cell Cycle 6: 3078-3085.

Omiecinski CJ, Remmel RP, and Hosagrahara VP (1999) Concise review of the cytochrome P450s and their roles in toxicology. Toxicological Sciences : An Official Journal of the Society of Toxicology 48: 151-156. 
Omura T, and Sato R (1964a) The Carbon Monoxide-binding Pigment of Liver Microsomes: I. EVIDENCE FOR ITS HEMOPROTEIN NATURE. The Journal of Biological Chemistry 239: 2370-2378.

Omura T, and Sato R (1964b) The Carbon Monoxide-binding Pigment of Liver Microsomes: II. SOLUBILIZATION, PURIFICATION, AND PROPERTIES. The Journal of Biological Chemistry 239: 2379-2385.

Onzalez FJG (2008) Regulation of Hepatocyte Nuclear Factor 4a-mediated Transcription. Drug Metabolism and Pharmacokinetics 23: 2-7.

Ostrow JD, Pascolo L, Brites D, and Tiribelli C (2004) Molecular basis of bilirubininduced neurotoxicity. Trends in Molecular Medicine 10: 65-70.

Ow Y-LP, Green DR, Hao Z, and Mak TW (2008) Cytochrome c: functions beyond respiration. Nature Reviews. Molecular Cell Biology 9: 532-542.

Pelkonen O, Rautio A, Raunio H, and Pasanen M (2000) CYP2A6: a human coumarin 7hydroxylase. Toxicology 144: 139-147.

Pelkonen P, Lang MA, Wild CP, Negishi M, and Juvonen RO (1994) Activation of aflatoxin B1 by mouse CYP2A enzymes and cytotoxicity in recombinant yeast cells. European Journal of Pharmacology 292: 67-73.

Pellinen P, Honkakoski P, Stenbäck F, Niemitz M, Alhava E, Pelkonen O, Lang MA, and Pasanen M (1994a) Cocaine N-demethylation and the metabolism-related hepatotoxicity can be prevented by cytochrome P450 3A inhibitors. European Journal of Pharmacology 270: $35-43$.

Pellinen P, Stenbäck F, Raunio H, Pelkonen O, and Pasanen M (1994b) Modification of hepatic cytochrome $\mathrm{P} 450$ profile by cocaine-induced hepatotoxicity in DBA/2 mouse. European Journal of Pharmacology 292: 57-65.

Pellinen P, Stenbäck F, Rautio A, Pelkonen O, Lang MA, and Pasanen M (1993) Archivesof Pharmacology dependence on strain and agent and comparison to other monooxygenases. Archives of Pharmacology 348: 435-443.

Pickett CB (1989) Glutathione S-transferases: Gene structure, regulation, and biological function. Annual Review of Biochemistry 58: 743-764.

Piras E, Franzen A, Fernandez EL, Bergstrom U, Raffalli-Mathieu F, Lang MA, and Brittebo EB (2003) Cell-specific Expression of CYP2A5 in the Mouse Respiratory Tract: Effects of Olfactory Toxicants. Journal of Histochemistry \& Cytochemistry 51: 15451555. 
Poland A, and Glover E (1975) Genetic Expression of Aryl Hydrocarbon Hydroxylase by 2,3,7,8-Tetrachlorodibenzo-p-dioxin: Evidence for a Receptor Mutation in Genetically Non-responsive Mice. Molecular Pharmacology 11: 389-398.

Porter TD, and Coon MJ (1991) Cytochrom P-450: Multiplicity of Isoforms, substrates, and catalytic and regulatory mechanisms. The Journal of Biological Chemistry 266: 13469-13472.

Prochaska HJ, and Talalay P (1988) Regulatory Mechanisms of Monofunctional and Bifunctional Anticarcinogenic Enzyme Inducers in Murine Liver. Cancer Research 48: 4776-4782.

Purdom-dickinson SE, Sheveleva E V, Sun H, and Chen QM (2007) Translational Control of Nrf2 Protein in Activation of Antioxidant Response by Oxidants. 72: 10741081.

Raffalli-Mathieu F, Glisovic T, Ben-David Y, and Lang MA (2002) Heterogeneous nuclear ribonucleoprotein A1 and regulation of the xenobiotic-inducible gene Cyp2a5. Molecular Pharmacology 61: 795-799.

Reed GA, Lasker JM, Eling TE, and Sivarajah K (1985) Peroxidative oxidation of bilirubin during prostaglandin biosynthesis. Prostaglandins 30: 153-165.

Richardson TA, Sherman M, Antonovic L, Kardar SS, Strobel HW, Kalman D, and Morgan ET (2006a) HEPATIC AND RENAL CYTOCHROME P450 GENE REGULATION DURING CITROBACTER RODENTIUM INFECTION IN WILDTYPE AND TOLL-LIKE RECEPTOR 4 MUTANT MICE. Drug Metabolism and Disposition 34: 354-360.

Richardson TA, Sherman M, Kalman D, and Morgan ET (2006b) EXPRESSION OF UDP-GLUCURONOSYLTRANSFERASE ISOFORM mRNAS DURING INFLAMMATION AND INFECTION IN MOUSE LIVER AND KIDNEY. Drug Metabolism and Disposition 34: 351-353.

Riedl SJ, and Salvesen GS (2007) The apoptosome: signalling platform of cell death. Nature Reviews. Molecular Cell Biology 8: 405-413.

Rodrigues CMP, Solá S, Brito MA, Brites D, and Moura J (2002) Bilirubin directly disrupts membrane lipid polarity and fluidity, protein order, and redox status in rat mitochondria. Journal of Hepatology 36: 335-341.

Ron D, and Walter P (2007) Signal integration in the endoplasmic reticulum unfolded protein response. Nature Reviews. Molecular Cell Biology 8: 519-529. 
Rosenfeld JM, Vargas R, Xie W, and Evans RM (2003) Genetic profiling defines the xenobiotic gene network controlled by the nuclear receptor pregnane $\mathrm{X}$ receptor. Molecular Endocrinology 17: 1268-1282.

Roth A, Looser R, Kaufmann M, Bla SM, Rencurel F, Huang W, Moore DD, and Meyer UA (2008) Regulartory Cross-Talk between Drug Metabolism and Lipid Homeostasis: Constitutive Androstane Receptor and Pregnane X Receptor Increase Insig-1 Expression. Molecular Pharmacology 73: 1282-1289.

Roy-Chowdhury N, Lu Y, and Roy-Chowdhury J (2007) Bilirubin Metabolism. In The Textbook of Hepatology, pp. 165-174.

Rushmore TH, Morton MR, and Pickett CB (1991) The antioxidant responsive element. Activation by oxidative stress and identification of the DNA consensus sequence required for functional activity. The Journal of Biological Chemistry 266: 11632-11639.

Salonpää P, Kottari S, Pelkonen O, and Raunio H (1997) Regulation of CYP2A5 induction by porphyrinogenic agents in mouse primary hepatocytes. NaunynSchmiedeberg's Archives of Pharmacology 355: 8-13.

Salonpää P, Krause K, Pelkonen O, and Raunio H (1995) Up-regulation of CYP2A5 expression by porphyrinogenic agents in mouse liver. Naunyn-Schmiedeberg's Archives of Pharmacology 351: 446-452.

Salonpää P, Pelkonen O, Kojo A, Pasanen M, Negishi M, and Raunio H (1994) Cytochrome P4502A5 expression and inducibility by phenobarbital is modulated by cAMP in mouse primary hepatocytes. Biochemical and Biophysical Research Communications 205: 631-637.

Sangar MC, Bansal S, and Avadhani NG (2010) Bimodal targeting of microsomal cytochrome P450s to mitochondria: implications in drug metabolism and toxicity. Expert Opinion on Drug Metabolism \& Toxicology 6: 1231-1251.

Schrem H, Klempnauer J, and Borlak J (2002) Liver-enriched transcription factors in liver function and development. Part I: the hepatocyte nuclear factor network and liverspecific gene expression. Pharmacological Reviews 54: 129-158.

Sekhar KR, Yan XX, and Freeman ML (2002) Nrf2 degradation by the ubiquitin proteasome pathway is inhibited by KIAA0132, the human homolog to INrf2. Oncogene 21: 6829-6834.

Seubert JM, Darmon AJ, El-Kadi AOS, D’Souza SJ a, and Bend JR (2002) Apoptosis in murine hepatoma hepa 1c1c7 wild-type, $\mathrm{C} 12$, and $\mathrm{C} 4$ cells mediated by bilirubin. Molecular Pharmacology 62: 257-264. 
Silva RFM, Mata LM, Gulbenkian S, and Brites D (2001) Endocytosis in rat cultured astrocytes is inhibited by unconjugated bilirubin. Neurochemical Research 26: 793-800.

Sipowicz MA, Chomarat P, Diwan BA, Anver MA, Awasthi YC, Ward JM, Rice JM, Kasprzak KS, Wild CP, and Anderson LM (1997) Increased oxidative DNA damage and hepatocyte overexpression of specific cytochrome P450 isoforms in hepatitis of mice infected with Helicobacter hepaticus. The American Journal of Pathology 151: 933-941.

Siu ECK, Wildenauer DB, and Tyndale RF (2006) Nicotine self-administration in mice is associated with rates of nicotine inactivation by CYP2A5. Psychopharmacology 184: 401-408.

Sladek FM (1993) Orphan receptor HNF-4 and liver-specific gene expression. Receptor 3: $223-232$.

Steeg E Van De, Wagenaar E, Kruijssen CMM Van Der, Burggraaff JEC, Waart DR De, Elferink RPJO, Kenworthy KE, and Schinkel AH (2010) Organic anion transporting polypeptide $1 \mathrm{a} / 1 \mathrm{~b}$-knockout mice provide insights into hepatic handling of bilirubin, bile acids, and drugs. The Journal of the Clinical Investigation 120: .

Stocker R, Yamamoto Y, McDonagh AF, and Glazer AN (1987) Bilirubin is an Antioxidant of Possible Physiological Importance. Science 235: 1043-1046.

Stoffel M, and Duncan SA (1997) The maturity-onset diabetes of the young (MODY1) transcription factor HNF4a regulates expression of genes required for glucose transport and metabolism. Proceedings of the National Academy of Sciences of the United States of America 94: 13209-13214.

Strange RC, Spiteri M a, Ramachandran S, and Fryer a a (2001) Glutathione-Stransferase family of enzymes. Mutation Research 482: 21-26.

Su T, and Ding X (2004) Regulation of the cytochrome P450 2A genes. Toxicology and Applied Pharmacology 199: 285-294.

Su T, Sheng JJ, Lipinskas TW, and Ding X (1996) EXPRESSION OF CYP2A GENES AND NASAL MUCOSA. Drug Metabolism and Disposition 24: 884-889.

Sueyoshi T, and Negishi M (2001) Phenobarbital Response Elements of Cytochome P450 Genes and Nuclear Receptors. Annual Review of Toxicology 500: 123-143.

Tenhunen R, Marver HS, and Schmid R (1969) Microsomal heme oxygenase: Characterization of the enzyme. The Journal of Biological Chemistry 244: 6388-6394.

Tenhunen R, Ross ME, Marver HS, and Schmid R (1970) Reduced nicotinamide-adenine dinucleotide phosphate dependent biliverdin reductase: partial purification and characterization. Biochemistry 9: 298-303. 
Testa B, and Kramer SD (2007) The Biochemistry of Drug Metabolism - An Introduction. Chemistry and Biodiversity 4: 257-405.

Tilloy-ellul A, Raffalli-Mathieu F, and Lang MA (1999) Analysis of RNA-protein interactions of mouse liver cytochrome P4502A5 mRNA. Biochemical Journal 703: 695703.

Timsit YE, and Negishi M (2007) CAR and PXR: the xenobiotic-sensing receptors. Steroids 72: 231-246.

Tzameli I, Pissios P, Schuetz EG, and Moore DD (2000) The Xenobiotic Compound 1,4Bis[2-(3,5-Dicholorophyridyloxy)]Benzene Is an Agonist Ligand for the Nuclear Receptor CAR. Molecular and Cellular Biology 20: 2951-2958.

Ulvila J, Arpiainen S, Pelkonen O, Aida K, Sueyoshi T, Negishi M, and Hakkola J (2004) Regulation of Cyp2a5 transcription in mouse primary hepatocytes: roles of hepatocyte nuclear factor 4 and nuclear factor I. The Biochemical Journal 381: 887-894.

Vaz AR, Silva SL, Barateiro A, Fernandes A, Falcão AS, Brito MA, and Brites D (2011) Pro-inflammatory cytokines intensify the activation of NO/NOS, JNK1/2 and caspase cascades in immature neurons exposed to elevated levels of unconjugated bilirubin. Experimental Neurology 229: 381-390.

Viitala P, Posti K, Lindfors A, Pelkonen O, and Raunio H (2001) cAMP mediated upregulation of CYP2A5 in mouse hepatocytes. Biochemical and Biophysical Research Communications 280: 761-767.

Wang H, Faucette S, Sueyoshi T, Moore R, Ferguson SS, Negishi M, and LeCluyse EL (2003a) A novel distal enhancer module regulated by pregnane $\mathrm{X}$ receptor/constitutive androstane receptor is essential for the maximal induction of CYP2B6 gene expression. The Journal of Biological Chemistry 278: 14146-14152.

Wang P, Kim RB, Chowdhury JR, and Wolkoff AW (2003b) The human organic anion transport protein SLC21A6 is not sufficient for bilirubin transport. The Journal of Biological Chemistry 278: 20695-20699.

Weng Y, DiRusso CC, Reilly A a, Black PN, and Ding X (2005) Hepatic gene expression changes in mouse models with liver-specific deletion or global suppression of the NADPH-cytochrome P450 reductase gene. Mechanistic implications for the regulation of microsomal cytochrome P450 and the fatty liver phenotype. The Journal of Biological Chemistry 280: 31686-31698.

Willson TM, and Kliewer S a (2002) PXR, CAR and drug metabolism. Nature Reviews. Drug Discovery 1: 259-266. 
Wisely GB, Miller AB, Davis RG, Thornquest AD, Johnson R, Spitzer T, Sefler A, Shearer B, Moore JT, Miller AB, et al. (2002) Hepatocyte nuclear factor 4 is a transcription factor that constitutively binds fatty acids. Structure 10: 1225-1234.

Wolkoff AW, Goresky CA, Sellin J, Gatmaitan Z, and Arias IM (2012) Role of ligandin in transfer of bilirubin from plasma into liver. American Journal of Physiology Gastrointestinal and Liver Physiology 236: G638-G648.

Wolkoff AW, Ketley JN, Waggoner JG, Berk PD, and Jakoby WB (1978) Hepatic accumulation and intracellular binding of conjugated bilirubin. The Journal of Clinical Investigation 61: 142-149.

Xie F, Zhou X, Genter MB, Behr M, Gu J, and Ding X (2011) The Tissue-Specific Toxicity of Methimazole in the Mouse Olfactory Mucosa Is Partly Mediated through Target-Tissue Metabolic Activation by CYP2A5. Drug Metabolism and Disposition 39: 947-951.

Yates MS, Tran QT, Dolan PM, Osburn WO, Shin S, McCulloch CC, Silkworth JB, Taguchi K, Yamamoto M, Williams CR, et al. (2009) Genetic versus chemoprotective activation of Nrf2 signaling: overlapping yet distinct gene expression profiles between Keap1 knockout and triterpenoid-treated mice. Carcinogenesis 30: 1024-1031.

Yuan X, Ta TC, Lin M, Evans JR, Dong Y, Bolotin E, Sherman MA, Forman BM, and Sladek FM (2009) Identification of an endogenous ligand bound to a native orphan nuclear receptor. PloS One 4: e5609.

Zaccaro C, Sweitzer S, Pipino S, Gorman N, Sinclair PR, Sinclair JF, Nebert DW, and De Matteis F (2001) Role of cytochrome P450 1A2 in bilirubin degradation Studies in Cyp1a2 (-/-) mutant mice. Biochemical Pharmacology 61: 843-849.

Zhou X, D'Agostino J, Moore CD, Yost GS, and Ding X (2012) Respective Roles of CYP2A5 and CYP2F2 in the Bioactivation of 3-Methylindole in Mouse Olfactory Mucosa and Lung: Studies Using Cyp2a5-Null and Cyp2f2-Null Mouse Models. Drug Metabolism and Disposition 40: 642-647. 


\section{APPENDIX I}

\section{CELL CULTURE - PRIMARY HEPATOCYTES}

\section{$\underline{0.1 \mathrm{M} \text { EGTA, } \mathrm{pH} 7.4}$}

- Dissolve $0.95 \mathrm{~g}$ EGTA in $1 \mathrm{~mL}$ of $5 \mathrm{~N} \mathrm{NaOH}$

- $\quad$ Add 2.5 mL of 10X Hanks' Buffered Salt Solution (HBSS) and $17 \mathrm{~mL}$ of MilliQ $\mathrm{H}_{2} \mathrm{O}$

- $\quad$ Adjust $\mathrm{pH}$ to 7.4 with $1 \mathrm{~N} \mathrm{HCl}$ and bring to final volume of $25 \mathrm{~mL}$ with MilliQ $\mathrm{H}_{2} \mathrm{O}$

- $\quad$ The solution was sterilized by filtration through a $0.45 \mu \mathrm{m}$ pore filter

\subsection{HEPES, pH 7.4}

- Purchased from Invitrogen (Burlington, ON)

Geneticin $50 \mathrm{mg} / \mathrm{mL}$

- Purchased from Invitrogen (Burlington, ON)

\section{$\underline{7.5 \% \text { BSA }}$}

- Dissolve $0.75 \mathrm{~g}$ of BSA (fraction V) in $8 \mathrm{~mL}$ MilliQ $\mathrm{H}_{2} \mathrm{O}$

- $\quad$ Bring to final volume of $10 \mathrm{~mL}$ with MilliQ $\mathrm{H}_{2} \mathrm{O}$

Insulin-Transferrin-Selenium (ITS)

- Purchased as lyophilized powder from Roche Diagnostics (Mississauga, ON)

- The powder contains of $25 \mathrm{mg}$ insulin, $25 \mathrm{mg}$ transferrin, $25 \mu \mathrm{g}$ sodium selenite

- The powder was reconstituted in $5 \mathrm{~mL}$ MilliQ $\mathrm{H}_{2} \mathrm{O}$ to give $1000 \mathrm{X}$ stock solution

$10 \mathrm{mM}$ Dexamethasone

- Dissolve $3.925 \mathrm{mg}$ dexamethasone in $1 \mathrm{~mL}$ ethanol 


\section{William's E Media}

- Dissolve entire contents of William's E powder purchased from Sigma-Aldrich (Oakville, ON) in $1 \mathrm{~L}$ MilliQ $\mathrm{H}_{2} \mathrm{O}$

- $\quad$ Add $2.2 \mathrm{~g} \mathrm{NaHO}_{3}$ and $\mathrm{pH}$ to 7.37 - 7.39

Blanching Solution

- $\quad$ 1.0 M HEPES, $\mathrm{pH} 7.4 \quad 1 \mathrm{~mL}$

- $\quad 0.1$ M EGTA, pH $7.4 \quad 1 \mathrm{~mL}$

- $10 X$ HBSS $10 \mathrm{~mL}$

- $\quad$ MilliQ $\mathrm{H}_{2} \mathrm{O} \quad 88 \mathrm{~mL}$

Collagenase Medium

- William's Media E $\quad 60 \mathrm{~mL}$

- $\quad$ 1.0 M HEPES, pH 7.4 $\quad 0.6 \mathrm{~mL}$

- $7.5 \%$ BSA $64 \mu \mathrm{L}$

- Collagenase Type III $\quad 28.6 \mathrm{mg}$

Attachment Medium

- William's Media E

$444.5 \mathrm{~mL}$

- ITS

$500 \mathrm{uL}$

- FBS (heat-inactivated) $\quad 50 \mathrm{~mL}$

- $10 \mathrm{mM}$ dexamethasone $\quad 2.5 \mathrm{uL}$

- 1.0 M HEPES, pH $7.4 \quad 5 \mathrm{~mL}$

- Geneticin $75 \mu \mathrm{L}$

$\underline{\text { Serum-Free Medium }}$

- William's Media E

$494.5 \mathrm{~mL}$

- ITS

$500 \mu \mathrm{L}$

- $\quad$ 1.0 M HEPES, pH $7.4 \quad 5$ mL 


\section{CELL CUTURE - HEPA 1-6}

Phosphate-buffered saline (PBS), $\mathrm{pH} 7.4$

- $\mathrm{NaCl}$

$8 \mathrm{~g}$

$-\mathrm{KCl}$

$0.2 \mathrm{~g}$

- $\mathrm{Na}_{2} \mathrm{HPO}_{4} 7 \mathrm{H}_{2} \mathrm{O}$

$2.68 \mathrm{~g}$

- $\mathrm{KH}_{2} \mathrm{PO}_{4}$

$0.24 \mathrm{~g}$

- MilliQ $\mathrm{H}_{2} \mathrm{O}$

$900 \mathrm{~mL}$

- $\mathrm{pH}$ to 7.4 and bring final volume to $1 \mathrm{~L}$ with MilliQ $\mathrm{H}_{2} \mathrm{O}$, and autoclave

Dulbecco's Modified Eagle's Medium (DMEM)

- Purchased from Sigma-Aldrich (Oakville, ON)

\section{Penicillin/Streptomycin}

- $100 \mathrm{X}$ stock solution was purchased from Sigma-Aldrich (Oakville, ON)

- The stock contains 10,000 units of penicillin and $10 \mathrm{mg}$ streptomycin/mL

\section{Complete media}

- FBS

- Penicillin/Streptomycin

- DMEM
$50 \mathrm{~mL}$

$5 \mathrm{~mL}$

$445 \mathrm{~mL}$ 


\section{BILIRUBIN STOCK PREPARATION}

** Bilirubin is light sensitive, so must work in the dark room

** Eppendorf microcentrifuge tube must be light protective amber colored tube

$\underline{0.1 \mathrm{~N} \mathrm{NaOH} \text { PBS, } \mathrm{pH} 7.4}$

- $1 \mathrm{~N} \mathrm{NaOH} \quad 1 \mathrm{~mL}$

- $\quad$ PBS, pH $7.4 \quad 9 \mathrm{~mL}$

$5 \mathrm{mM}$ Bilirubin

- Bilirubin of mixed isomers was purchased from Sigma-Aldrich (Oakville, ON)

- $\quad$ Dissolve $29.23 \mathrm{mg}$ of bilirunin in $10 \mathrm{~mL} 0.1 \mathrm{~N} \mathrm{NaOH}$ PBS, pH 7.4

- Dilute $5 \mathrm{mM}$ stock bilirubin into $2.5 \mathrm{mM}, 1.0 \mathrm{mM}, 0.1 \mathrm{mM}$ stock 


\section{WESTERN BLOTS}

2.0 M Tris- $\mathrm{HCl}, \mathrm{pH} 6.8$

- $\quad$ Tris Base $12.59 \mathrm{~g}$

- MilliQ $\mathrm{H}_{2} \mathrm{O}$

- $\mathrm{pH}$ to 6.8 with $12 \mathrm{~N} \mathrm{HCl}$ and adjust to final volume of $50 \mathrm{~mL}$ with MilliQ $\mathrm{H}_{2} \mathrm{O}$

- when adjusting $\mathrm{pH}$, cool it down with ice as $12 \mathrm{~N} \mathrm{HCl}$ is being added

$\underline{1.5 \mathrm{M} \text { Tris- } \mathrm{HCl}, \mathrm{pH} 8.8}$

- $\quad 27.26 \mathrm{~g}$

- MilliQ $\mathrm{H}_{2} \mathrm{O}$

- $\mathrm{pH}$ to 8.8 with $6 \mathrm{~N} \mathrm{HCl}$ and adjust to final volume of $150 \mathrm{~mL}$ with MilliQ $\mathrm{H}_{2} \mathrm{O}$

$\underline{1.0 \mathrm{M} \text { Tris- } \mathrm{HCl}, \mathrm{pH} 7.5}$

- Tris Base $\quad 12.0 \mathrm{~g}$

- MilliQ $\mathrm{H}_{2} \mathrm{O}$

- $\mathrm{pH}$ to 7.5 with $6 \mathrm{~N} \mathrm{HCl}$ and adjust to final volume of $100 \mathrm{~mL}$ with MilliQ $\mathrm{H}_{2} \mathrm{O}$

0.5 M Tris- $\mathrm{HCl}, \mathrm{pH} 6.8$

- Tris Base $6.0 \mathrm{~g}$

- MilliQ $\mathrm{H}_{2} \mathrm{O}$

- $\mathrm{pH}$ to 6.8 with $6 \mathrm{~N} \mathrm{HCl}$ and adjust to final volume of $100 \mathrm{~mL}$ with MilliQ $\mathrm{H}_{2} \mathrm{O}$

$10 \%$ SDS

- SDS $10 \mathrm{~g}$

- MilliQ $\mathrm{H}_{2} \mathrm{O} \quad 90 \mathrm{~mL}$

- $\quad$ Adjust to final volume of $100 \mathrm{~mL}$ with MilliQ $\mathrm{H}_{2} \mathrm{O}$

$1 \%$ Bromophenol blue

- bromophenol blue $\quad 100 \mathrm{mg}$

- MilliQ $\mathrm{H}_{2} \mathrm{O} \quad 10 \mathrm{~mL}$ 
2X Laemmli Buffer

- $\quad 2.0 \mathrm{M}$ Tris- $\mathrm{HCl}, \mathrm{pH} 6.8 \quad 1.250 \mathrm{~mL}$

- $\beta$-mercaptoethanol $2 \mathrm{~mL}$

- MilliQ $\mathrm{H}_{2} \mathrm{O} \quad 10 \mathrm{~mL}$

- SDS $800 \mathrm{mg}$

- Glycerol $4 \mathrm{~mL}$

- $1 \%$ bromophenol blue $\quad 80 \mu \mathrm{L}$

- Adjust final volume to $20 \mathrm{~mL}$ with MilliQ $\mathrm{H}_{2} \mathrm{O}(\sim 2.5 \mathrm{~mL})$

- $\quad \beta$-mercaptoethanol is light sensitive, so aliquot in amber microcentrifuge tubes and keep it at $-20{ }^{\circ} \mathrm{C}$

5X Laemmli Buffer (order of addition is important)

- $\quad 2.0 \mathrm{M}$ Tris-HCl, $\mathrm{pH} 6.8 \quad 3.125 \mathrm{~mL}$

- $\beta$-mercaptoethanol $5 \mathrm{~mL}$

- SDS $2 \mathrm{~g}$ (dissolve completely before proceed)

- Glycerol $10 \mathrm{~mL}$ (add slowly)

- $1 \%$ bromophenol blue $\quad 200 \mu \mathrm{L}$

- Adjust final volume to $20 \mathrm{~mL}$ with MilliQ $\mathrm{H}_{2} \mathrm{O}(\sim 1.8 \mathrm{~mL})$

- $\quad \beta$-mercaptoethanol is light sensitive, so aliquot in amber microcentrifuge tubes and keep it at $-20{ }^{\circ} \mathrm{C}$

5X Running Buffer, $\mathrm{pH} 8.3$

- Tris Base

$15.0 \mathrm{~g}$

$30 \mathrm{~g}$

$45 \mathrm{~g}$

$60 \mathrm{~g}$

- Glycine

$72.0 \mathrm{~g}$

$144 \mathrm{~g}$

$216 \mathrm{~g}$

$288 \mathrm{~g}$

- SDS

$5.0 \mathrm{~g}$

$10 \mathrm{~g}$

$15 \mathrm{~g}$

$20 \mathrm{~g}$

- MilliQ $\mathrm{H}_{2} \mathrm{O}$

\begin{tabular}{llll}
\hline $1 \mathrm{~L}$ & $2 \mathrm{~L}$ & $3 \mathrm{~L}$ & $4 \mathrm{~L}$
\end{tabular}

Transfer Buffer, $\mathrm{pH} 8.3$

- Tris Base

- Glycine
$3.03 \mathrm{~g}$

$14.4 \mathrm{~g}$

$6.06 \mathrm{~g}$

$9.09 \mathrm{~g}$

$12.12 \mathrm{~g}$

$28.8 \mathrm{~g}$

$43.2 \mathrm{~g}$

$57.6 \mathrm{~g}$ 
- Methanol

- MilliQ $\mathrm{H}_{2} \mathrm{O}$
$200 \mathrm{~mL} \quad 400 \mathrm{~mL} \quad 600 \mathrm{~mL} \quad 800 \mathrm{~mL}$ final volume

$1 \mathrm{~L} \quad 2 \mathrm{~L} \quad 3 \mathrm{~L} \quad 4 \mathrm{~L}$

* Do not adjust $\mathrm{pH}$. Should be $\sim 8.1-8.4$; reuse $3 \mathrm{x}$

TBS (Tris buffered saline), pH 7.6 (recipe for ECL+)

- Tris Base

- $\mathrm{NaCl}$

- MilliQ $\mathrm{H}_{2} \mathrm{O}$

- Final volume
$2.4 \mathrm{~g} \quad 9.6 \mathrm{~g}$

$8.0 \mathrm{~g} \quad 32.0 \mathrm{~g}$

$800 \mathrm{~mL} \quad 3.2 \mathrm{~L}$

$1 \mathrm{~L} \quad 4 \mathrm{~L}$

* pH to 7.6 with $6 \mathrm{~N} \mathrm{HCl}$ and adjust to final volume

TTBS, $0.1 \%$ Tween 20 (recipe for ECL+)

- $\quad$ TBS, pH $7.6 \quad 999 \mathrm{~mL}$

- Tween $20 \quad 1 \mathrm{~mL}$

Cell Lysis Buffer (100 mL stock)

- $\quad$ 1.0 M Tris, pH $7.5 \quad 5 \mathrm{~mL}$

- $10 \%$ Glycerol $\quad 10 \mathrm{~mL}$

- $\quad 0.5$ M EDTA $\quad 1 \mathrm{~mL}$

- $\quad 2.5 \mathrm{M} \mathrm{NaCl}_{2} \quad 6 \mathrm{~mL}$

- $0.5 \%$ NP-40 $500 \mu \mathrm{L}$

- $\quad$ MilliQ $\mathrm{H}_{2} \mathrm{O} \quad 77.5 \mathrm{~mL}$

- Take $10 \mathrm{~mL}$ of stock and add one Complete mini tablet 


\section{NUCLEAR FRACTION EXTRACTION BUFFERS}

1.0 M HEPES-KOH, $\mathrm{pH} 7.9$

- $\quad$ 1.0 M HEPES, ph $7.4 \quad 45 \mathrm{~mL}$

- $\mathrm{pH}$ to 7.9 with $\mathrm{KOH}$ pellets

\section{$1.0 \mathrm{M} \mathrm{KCl}$}

- Dissolve $37.275 \mathrm{mg} \mathrm{KCl}$ in $50 \mathrm{~mL}$ MilliQ $\mathrm{H}_{2} \mathrm{O}$

- The solution was sterilized by filtration through a $0.45 \mu \mathrm{m}$ pore filter

\section{$1.0 \mathrm{M} \mathrm{MgCl}_{2}$}

- Dissolve $10.165 \mathrm{mg} \mathrm{MgCl}_{2}$ in $50 \mathrm{~mL}$ MilliQ $\mathrm{H}_{2} \mathrm{O}$

- The solution was sterilized by filtration through a $0.45 \mu \mathrm{m}$ pore filter

\section{$\underline{2.5 \mathrm{M} \mathrm{NaCl}_{2}}$}

- Dissolve $7.305 \mathrm{mg} \mathrm{NaCl}_{2}$ in $50 \mathrm{~mL}$ MilliQ $\mathrm{H}_{2} \mathrm{O}$

NP-40 Substitute

- Purchased from Santa Cruz Biotechnology (Santa Cruz, CA)

0.1 M Dithiothreitol (DTT)

- Dissolve $77.125 \mathrm{mg}$ DTT in $5 \mathrm{~mL}$ MilliQ $\mathrm{H}_{2} \mathrm{O}$

- DTT is light sensitive; aliquot in amber centrifuge tubes and store at $-20^{\circ} \mathrm{C}$

1.0 M EDTA, $\mathrm{pH} 8.0$

- Dissolve $18.6 \mathrm{~g} \mathrm{Na}_{2} \bullet$ EDTA $\bullet 2 \mathrm{H}_{2} \mathrm{O}$ in approximately $80 \mathrm{~mL}$ of MilliQ $\mathrm{H}_{2} \mathrm{O}$

- Add $2.2 \mathrm{~g} \mathrm{NaOH}$ pellets and once dissolved, adjust $\mathrm{pH}$ to 8.0 with $10 \mathrm{~N} \mathrm{NaOH}$

- $\quad$ ** EDTA does not dissolve completely until the $\mathrm{pH}$ reaches $\sim 8$

- Adjust final volume to $100 \mathrm{~mL}$ with MilliQ $\mathrm{H}_{2} \mathrm{O}$ 
Buffer A $(50 \mathrm{~mL})$

- $\quad$ 1.0 M HEPES-KOH, pH 7.9

$500 \mu \mathrm{L}$

- $\quad 1.0 \mathrm{M} \mathrm{KCl}$

$500 \mu \mathrm{L}$

- $\quad 1.0 \mathrm{M} \mathrm{MgCl}_{2}$

$75 \mu \mathrm{L}$

- NP-40

$200 \mu \mathrm{L}$

- MilliQ $\mathrm{H}_{2} \underline{\mathrm{O}}$

$48.725 \mathrm{~mL}$

- $\quad$ Take $10 \mathrm{~mL}$ of the stock, add $50 \mu \mathrm{L} 0.1 \mathrm{M}$ DTT and one Complete mini tablet

\section{$\underline{\text { Buffer B }}$}

- $\quad$ 1.0 M HEPES-KOH, pH 7.9

$1 \mathrm{~mL}$

- Glycerol

$12.5 \mathrm{~mL}$

- $\quad 1.0 \mathrm{M} \mathrm{MgCl} 2$

$75 \mu \mathrm{L}$

- $\quad 2.5 \mathrm{M} \mathrm{NaCl} 2$

$8.4 \mathrm{~mL}$

- $\quad 0.5$ M EDTA

$20 \mu \mathrm{L}$

- $\quad$ MilliQ $\mathrm{H}_{2} \underline{\mathrm{O}}$ $28.005 \mathrm{~mL}$

- $\quad$ Take $10 \mathrm{~mL}$ of the stock, add $50 \mu \mathrm{L} 0.1 \mathrm{M}$ DTT and one Complete mini tablet 


\section{MICROSOME EXTRACTION BUFFER}

Homogenization Buffer, $\mathrm{pH} 7.4$

- Tris Base

$1.2114 \mathrm{~g}$

- Sucrose $20 \mathrm{~g}$

- MilliQ $\mathrm{H}_{2} \mathrm{O} \quad 80 \mathrm{~mL}$

- $\mathrm{pH}$ to 7.4 with $6 \mathrm{~N} \mathrm{HCl}$ and adjust volume to $100 \mathrm{~mL}$

Microsome Storage Buffer, $\mathrm{pH} 7.4$

- Tris Base

$1.2114 \mathrm{~g}$

- Glycerol $10 \mathrm{~mL}$

- MilliQ $\mathrm{H}_{2} \mathrm{O} \quad 30 \mathrm{~mL}$

- $\mathrm{pH}$ to 7.4 with $6 \mathrm{~N} \mathrm{HCl}$ and adjust volume to $50 \mathrm{~mL}$

\section{REAGENTS FOR BILIRUBIN DISAPPEARANCE ASSAY}

1.0 M Tris- $\mathrm{HCl}, \mathrm{pH} 8.2$

- Tris Base $12.0 \mathrm{~g}$

- MilliQ $\mathrm{H}_{2} \mathrm{O} \quad 60 \mathrm{~mL}$

- $\mathrm{pH}$ to 8.2 with $6 \mathrm{~N} \mathrm{HCl}$ and adjust to final volume of $100 \mathrm{~mL}$ with MilliQ $\mathrm{H}_{2} \mathrm{O}$

\section{$1.3 \mathrm{M} \mathrm{KCl}$}

- Dissolve $9.6915 \mathrm{~g} \mathrm{KCl}$ in $10 \mathrm{~mL}$ MilliQ $\mathrm{H}_{2} \mathrm{O}$

2 mM Bilirubin (in DMSO)

- Dissolve $1.1692 \mathrm{mg}$ of bilirunin in $2 \mathrm{~mL}$ DMSO

- ** Bilirubin is light sensitive, so must work in the dark room

- ** Eppendorf microcentrifuge tube must be light protective amber colored tube 
TRANSFORMATION OF BACTERIA (to produce more expression vectors)

$\underline{\text { LB Broth }}$

- $\mathrm{NaCl}_{2} \quad 5 \mathrm{~g}$

- Tryptone $5 \mathrm{~g}$

- Yeast extract $2.5 \mathrm{~g}$

- MilliQ $\mathrm{H}_{2} \mathrm{O} \quad 450 \mathrm{~mL}$

- $\mathrm{pH}$ to 7.0 with $5 \mathrm{~N} \mathrm{NaOH}$, adjust final volume to $500 \mathrm{~mL}$

- Autoclave

$\underline{\text { LB Agar }(500 \mathrm{~mL} / 20 \text { plates })}$

- $\mathrm{NaCl}_{2}$ $5 \mathrm{~g}$

- Tryptone $5 \mathrm{~g}$

- Yeast extract $\quad 2.5 \mathrm{~g}$

- $\quad$ MilliQ $\mathrm{H}_{2} \mathrm{O} \quad 450 \mathrm{~mL}$

- $\mathrm{pH}$ to 7.0 with $5 \mathrm{~N} \mathrm{NaOH}$

- add $10 \mathrm{~g}$ bacto-agar

- ** agar will not dissolve until autoclaved

- Autoclave, cool to $<50^{\circ} \mathrm{C}$, add $500 \mu \mathrm{L}$ of ampicillin $(50 \mathrm{mg} / \mathrm{mL})$ 


\section{APPENDIX II - SOURCES OF MATERIALS}

6-well cell culture plate

7-ethoxycoumarin

7-hydroxycoumarin

24-well cell culture plate

96-well microplates (black, white, clear)

$100 \mathrm{~mm}$ cell culture dish

Acrylamide

Amersham Hybond ECL membrane

Ampicillin

Anti-mouse $\beta$-actin $\mathrm{Ab}$

Anti-mouse cleaved caspase- $3 \mathrm{Ab}$

Bilirubin

Bio-Rad protein assay reagent

Bottle Top Vacuum filter

BSA

C57BL/6 male mice

Cell culture flasks

Chicken anti-mouse Cyp2a5 Ab

Chloroform

Conical tubes

Coumarin
Corning Inc, Corning, NY

Sigma-Aldrich, Oakville, ON

Sigma-Aldrich, Oakville, ON

Corning Inc, Corning, NY

Corning Inc, Corning, NY

Corning Inc, Corning, NY

Bio-Rad Laboratories, Mississauga, ON

GE Healthcare, Oakville, ON

Sigma-Aldrich, Oakville, ON

Sigma-Aldrich, Oakville, ON

Cell Signaling, Whitby, ON

Sigma-Aldrich, Oakville, ON

Bio-Rad Laboratories, Mississauga, ON

Corning Inc, Corning, NY

Sigma-Aldrich, Oakville, ON

Charles River Canada, St Constant, QC

Corning Inc, Corning, NY

Dr. Juvonen, Kuopio, Finland

Fisher Scientific, Ottawa, ON

Fisher Scientific, Ottawa, ON

Sigma-Aldrich, Oakville, ON 
Cyp2a5 5'-3033/+10

CYP2A5-V5 expression vector

Dexamethasone

DMEM

DMSO

DNase

dNTP mix

DTT

Dual-Luciferase Reporter Assay System

ECL Plus

EDTA

EGTA

FastStart SYBR Green Master Mix

FBS

Geneticin

Glass dounce homogenizer

Glycerol

HBSS

Hepa 1-6 cell line

HEPES

HRP-conjugated goat anti-chicken IgG Ab

HRP-conjugated goat anti-mouse IgG Ab

HRP-conjugated goat anti-rabbit IgG Ab
Dr. Jukka Hakkola, Univ. of Oulu, Finland

Dr. Masahiko Negishi, NIEHS, USA

Sigma-Aldrich, Oakville, ON

Sigma-Aldrich, Oakville, ON

Sigma-Aldrich, Oakville, ON

Promega, Madison, WI

Invitrogen, Burlington, ON

Sigma-Aldrich, Oakville, ON

Promega, Madison, WI

Amersham Biosciences, Baie d'Urfe, QC

Sigma-Aldrich, Oakville, ON

Sigma-Aldrich, Oakville, ON

Roche Diagnostics, Mississauga, ON

Sigma-Aldrich, Oakville, ON

Invitrogen, Burlington, ON

Fisher Scientific, Ottawa, ON

Fisher Scientific, Nepean, ON

Invitrogen, Burlington, ON

ATCC, Manassa, VA

Sigma-Aldrich, Oakville, ON

Sigma-Aldrich, Oakville, ON

Sigma-Aldrich, Oakville, ON

Sigma-Aldrich, Oakville, ON 
ImageQuant TL

Isopropanol

ITS

Lipofectamine 2000

Lightcycler capillaries

Lunar reverse phase $\mathrm{C} 18$ column

Magnesium chloride

Methanol

M-MLV RT

Mouse collagenase type I

NADPH

NanoDrop ND-1000

NP-40 Alternative

Nrf2 HA-tagged expression vector

Nuclease-free water

pcDNA3.1/V5-His TOPO TA Exp. Kit

Pentobarbital

Penicillin/Streptomycin

POR-V5 expression vector

Potassium chloride

Precision plus molecular weight marker

Complete mini, protease inhibitor tablet

Random primers
GE Health Sciences, Piscataway, NJ

Fisher Scientific, Ottawa, ON

Roche Diagnostics, Laval, QC

Invitrogen, Burlington, ON

Roche Diagnostics, Mississauga, ON

Phenomenex, Torrance, CA

Sigma-Aldrich, Oakville, ON

Fisher Scientific, Nepean, ON

Promega, Madison, WI

Sigma-Aldrich, Oakville, ON

Sigma-Aldrich, Oakville, ON

Thermoscientific, Ottawa, ON

EMD Millipore, Billerica, MA

Dr. Ah-Ng Tony Kong, Univ. of NJ, USA

Ambion, Austin, TX

Invitrogen, Burlington, ON

MTC Pharmaceuticals, Cambridge, ON

Invitrogen, Burlington, ON

Dr. Jim Squires, Univ. of Guelph, ON

Fisher Scientific, Nepean, ON

Bio-Rad Laboratories, Mississauga, ON

Roche Diagnostics, Mississauga, ON

Invitrogen, Burlington, ON 
Renilla pRL-TK vector

RNase inhibitor

Roche Light Cycler

SDS

Sodium chloride

Spectra 100 UV-Vis detector

Spectra Physics HPLC system

TEMED

Tricholoroacetic acid

Tris base

Trizol reagent

TrypLE

Tryptone

Tygon tubes

Typhoon 9410 Scanner

Tween-20

Whatman filter paper

William's Medium E

Yeast extract
Promega, Madison, WI

Promega, Madison, WI

Roche Diagnostics, Indianapolis, IN

Fisher Scientific, Nepean, ON

Fisher Scientific, Nepean, ON

Spectra-Physics, San Jose, CA

Spectra-Physics, San Jose, CA

Invitrogen, Burlington, ON

Sigma-Aldrich, Oakville, ON

Fisher Scientific, Nepean, ON

Invitrogen, Burlington, ON

Invitrogen, Burlington, ON

Sigma-Aldrich, Oakville, ON

Fisher Scientific, Ottawa, ON

GE Health Sciences, Piscataway, NJ

Sigma-Aldrich, Oakville, ON

Fisher Scientific, Nepean, ON

Sigma-Aldrich, Oakville, ON

Sigma-Aldrich, Oakville, ON 